\title{
The changing radiative forcing of fires: global model estimates for past, present and future
}

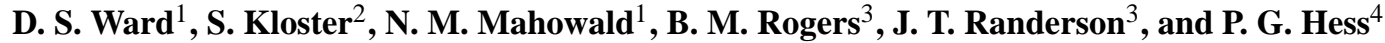 \\ ${ }^{1}$ Earth and Atmospheric Science, Cornell University, Ithaca, New York, USA \\ ${ }^{2}$ Land in the Earth System, Max Planck Institute for Meteorology, Hamburg, Germany \\ ${ }^{3}$ Earth System Science, University of California, Irvine, California, USA \\ ${ }^{4}$ Biological and Environmental Engineering, Cornell University, Ithaca, New York, USA
}

Correspondence to: D. S. Ward (dsw25@cornell.edu)

Received: 22 March 2012 - Published in Atmos. Chem. Phys. Discuss.: 24 April 2012

Revised: 6 November 2012 - Accepted: 9 November 2012 - Published: 16 November 2012

\begin{abstract}
Fires are a global phenomenon that impact climate and biogeochemical cycles, and interact with the biosphere, atmosphere and cryosphere. These impacts occur on a range of temporal and spatial scales and are difficult to quantify globally based solely on observations. Here we assess the role of fires in the climate system using model estimates of radiative forcing (RF) from global fires in preindustrial, present day, and future time periods. Fire emissions of trace gases and aerosols are derived from Community Land Model simulations and then used in a series of Community Atmosphere Model simulations with representative emissions from the years 1850, 2000, and 2100. Additional simulations are carried out with fire emissions from the Global Fire Emission Database for a present-day comparison. These results are compared against the results of simulations with no fire emissions to compute the contribution from fires. We consider the impacts of fire on greenhouse gas concentrations, aerosol effects (including aerosol effects on biogeochemical cycles), and land and snow surface albedo. Overall, we estimate that pre-industrial fires were responsible for a $\mathrm{RF}$ of $-1 \mathrm{~W} \mathrm{~m}^{-2}$ with respect to a pre-industrial climate without fires. The largest magnitude pre-industrial forcing from fires was the indirect aerosol effect on clouds $\left(-1.6 \mathrm{~W} \mathrm{~m}^{-2}\right)$. This was balanced in part by an increase in carbon dioxide concentrations due to fires $\left(+0.83 \mathrm{~W} \mathrm{~m}^{-2}\right)$. The RF of fires increases by $0.5 \mathrm{~W} \mathrm{~m}^{-2}$ from 1850 to 2000 and $0.2 \mathrm{~W} \mathrm{~m}^{-2}$ from 1850 to 2100 in the model representation from a combination of changes in fire activity and changes in the background environment in which fires occur, especially increases and decreases in the anthropogenic
\end{abstract}

aerosol burden. Thus, fires play an important role in both the natural equilibrium climate and the climate perturbed by anthropogenic activity and need to be considered in future climate projections.

\section{Introduction}

Fires impose a considerable forcing on the global climate through impacts on a diverse set of Earth system processes (Bowman et al., 2009). These include land and ice surface energy budgets, biogeochemical cycling, and physical and chemical processes in the atmosphere. Recent studies have quantified various aspects of fires' effects on climate. These studies have focused on specific impacts (e.g. Liu et al., 2005; Naik et al., 2007; Ito et al., 2007), certain types of fire emissions (e.g. Jacobson, 2004), or on fires that occur within a particular ecosystem or region (e.g. Randerson et al., 2006; Pfister et al., 2008; Stone et al., 2011). More general assessments highlight the complexity of these impacts, particularly those from aerosols, and the difficulty in performing a comprehensive analysis at a global scale (Forster et al., 2007; Bowman et al., 2009). As such, the sum radiative effect of fires remains fundamentally uncertain (Carslaw et al., 2010).

When an open fire burns, products of the combustion are released into the atmosphere as aerosols and trace gases, including important greenhouse gases (Fig. 1). Global emissions of carbon dioxide $\left(\mathrm{CO}_{2}\right)$ due to fires were estimated to be $2.0 \mathrm{Pg}$ carbon (C) $\mathrm{yr}^{-1}$ averaged from 1997 to 2009 by van der Werf et al. (2010), of which approximately $0.5 \mathrm{Pg} \mathrm{C} \mathrm{yr}^{-1}$ 


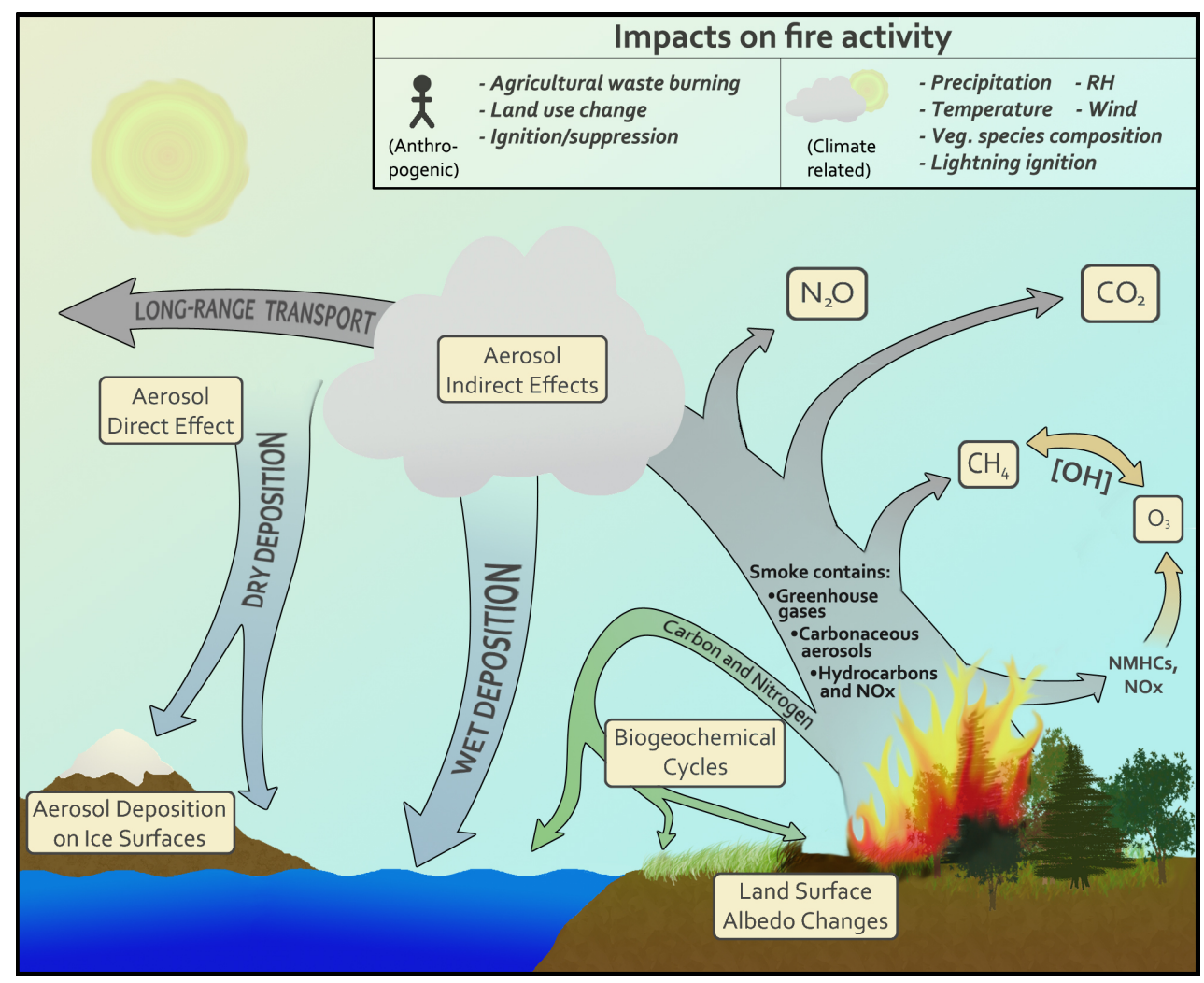

Fig. 1. A schematic illustrating the various impacts of fire on the atmosphere, land surface, ice surfaces and the ocean.

is associated with anthropogenic deforestation. Fire emissions also contain other key greenhouse gases, including methane $\left(\mathrm{CH}_{4}\right)$ and nitrous oxide $\left(\mathrm{N}_{2} \mathrm{O}\right)$ (Andreae and Merlet, 2001). Additionally, the flux of high concentrations of carbon monoxide $(\mathrm{CO})$, other non-methane hydrocarbons (NMHCs), and $\mathrm{NO}_{\mathrm{x}}\left(\mathrm{NO}+\mathrm{NO}_{2}\right)$ alters the oxidation capacity of the atmosphere, modifying $\mathrm{CH}_{4}$ lifetime and enhancing concentrations of the short-lived greenhouse gas, ozone $\left(\mathrm{O}_{3}\right)$ (Ito et al., 2007).

Fires are presently the largest source of primary carbonaceous aerosol mass globally (Andreae and Rosenfeld, 2008). Aerosol emissions from fires consist mainly of organic carbon (OC) (Galanter et al., 2000; Andreae and Merlet, 2001) but also contribute to global black carbon (BC) emissions (Schwarz et al., 2008; Mieville et al., 2010). Together, these particles scatter and absorb radiation, exerting a direct aerosol effect on the radiation budget. In addition, aerosols alter climate by their impacts on clouds. Some aerosol species, especially BC, add heat to the cloud environment leading to evaporation, which alters the radiative balance (the semi-direct effect), and aerosols act as cloud condensation nuclei and ice nuclei to modify the cloud albedo and lifetime (Lohmann and Feichter, 2005). Fire aerosols can apply further forcing onto the climate by transporting nutrients or toxins to sensitive ecosystems (Chen et al., 2010; Mahowald, 2011), and by being deposited on snow and ice surfaces, reducing the surface albedo (Hadley et al., 2010; Flanner et al., 2007; 2009).

In the immediate aftermath of a fire, charring of the surface reduces the albedo of the burned area. However, fires also open forest canopies, which can expose higher albedo surfaces such as grass and shrub vegetation, or snow, leading to a negative radiative forcing (Randerson et al., 2006). Over a period of years to decades, post-fire changes in the age and composition of vegetation can alter the surface energy budget (Liu et al., 2005) and the local biogeochemical cycling (Thonicke et al., 2001; Thornton et al., 2007).

Fires occur naturally and have for millions of years prior to human influences (Bowman et al., 2009). In recent times however, human activity has played a role in both igniting and suppressing fires, as well as modifying fire regimes through land use and land cover change (Marlon et al., 2008). Fires are likely to respond to future climate changes since fire activity depends on precipitation, temperature, and humidity trends (Flannigan et al., 2009). Recent development of global fire prediction schemes (Thonicke et al., 2001, 2010; Arora and Boer, 2005; Prentice et al., 2011) has made it possible to simulate the spatial distribution of pre-satellite era and future fire emissions.

In this study, global fire emissions were derived from simulations documented by Kloster et al. $(2010,2012)$ using a modified form of the Community Land Model (CLM) 
version 3.5, hereafter CLM3 (Oleson et al., 2008a; Stockli et al., 2008). Fire activity is predicted in CLM3 with the coupled carbon-fire model implemented by Kloster et al. (2010) building on work from Arora and Boer (2005). The model combines fuel availability, fuel moisture content and ignition probabilities with windspeed to predict the area burned from open fires. Kloster et al. (2010) introduced an anthropogenic impact on fire ignition and suppression based on human population. Emissions from deforestation fires, fires intentionally set to clear land for agriculture, are represented as a fraction of the $\mathrm{C}$ lost due to land cover change. The fraction is predicted as a function of the fuel moisture content with higher fractions in dry areas.

Kloster et al. (2010, 2012) modeled fires from a preindustrial base state through the year 2100, and accounted for the impacts of changes in $\mathrm{CO}_{2}$ concentrations, climate (after 1948), and human activities, on fire area burned. The 20th century saw a small (less than $15 \%$ ) decreasing trend in global fire emissions, mainly due to changes in land use and human population (Kloster et al., 2010). Global fire emissions then increased between $17 \%$ and $62 \%$ from the present day to the years 2075 to 2099. Kloster et al. (2012) found that while projected climate changes led to increased global fire emissions, these could be offset in part by future changes in human population and land use. Here we build on these studies by evaluating how past and projected future changes in fire activity impact the climate.

We use the concept of radiative forcing (RF) as a measure of climate impacts and their relative importance. RF is often defined as a perturbation to the net radiative flux at the top of the atmosphere or the tropopause relative to the pre-industrial state (Ramaswamy et al., 2001). Here we are calculating radiative flux perturbations relative to a global state without fires. This could be referred to as the radiative forcing of the direct effects of fire-related processes. For simplicity, we use the term RF to represent the radiative forcing of the direct effect of fires and will refer to differences in the RF relative to the pre-industrial state as changes in the RF.

We estimate the global RF of fires for 1850, 2000, and 2100 by their impacts on long-lived greenhouse gases $\left(\mathrm{CO}_{2}\right.$, $\left.\mathrm{CH}_{4}, \mathrm{~N}_{2} \mathrm{O}\right), \mathrm{O}_{3}$, the aerosol direct effect, aerosol indirect effects, aerosol deposition on snow/ice surfaces, surface albedo changes and changes to biogeochemical cycles (Fig. 1) using a modeling approach described in the following section.

\section{Methods}

The RFs of the fire impacts shown in Fig. 1 are computed by differencing an atmosphere that includes fire emissions from the same atmosphere without fire emissions. In the absence of fire emissions, non-fire trace gases and aerosols will evolve differently than in the simulation that includes all anthropogenic and natural emissions. In this section we discuss the setup of the atmosphere model, the estimation of fire emissions, and the method for calculating each individual RF.

\subsection{Model setup}

The "fire" and "no-fire" approach is applied to two sets of atmosphere simulations using the National Center for Atmospheric Research (NCAR) Community Atmosphere Model (CAM) release versions 4 and 5. Within CAM4 we run online chemistry from the Model for Ozone and Related chemical Tracers (MOZART), version 4 (Emmons et al., 2010; Lamarque et al., 2012). Many aspects of CAM were updated for version 5 (Liu et al., 2011) including the cloud microphysics. CAM5 includes the two-moment cloud microphysical scheme for stratiform clouds described by Morrison and Gettelman (2008), which enables prediction of the size of various hydrometeors. With this new scheme, aerosol/cloud interactions and indirect effects can be simulated for stratiform clouds. Aerosol effects on convective clouds are not included in CAM5. We use the three-mode Modal Aerosol Model (MAM3) (Liu et al., 2012) in CAM5. MAM3 predicts aerosol mass mixing ratios and number mixing ratios for major aerosol species (excluding nitrate aerosols) in three lognormal modes: Aitken, accumulation and coarse. Primary carbonaceous aerosols are emitted directly into internal mixtures with other accumulation mode species.

CAM is setup with a grid spacing of the finite volume dynamics core of 1.9 degrees latitude by 2.5 degrees longitude and 26 vertical levels, with a $30 \mathrm{~min}$ timestep. All simulations are branched from a two-year spinup of year 2000 climate conditions (temperature, solar forcing, sea surface temperature, etc.). The model setup after spinup is identical for all simulations except that trace gas and aerosol emissions, both fire and non-fire, and initial $\mathrm{CH}_{4}$ concentrations (that affect tropospheric chemistry) are case specific. In this way the impact of the change in emissions is isolated from other climate factors. CAM is run for an additional spinup year after the change in emissions. The impact of fire on surface albedo is not predicted by CAM. Instead, we compute the RF from this effect offline.

Two groups of eight CAM simulations are run with this setup (Table 1). The CHEM group of simulations uses CAM4 and MOZART chemistry, with a focus on the impacts of fires on $\mathrm{O}_{3}$ and the oxidation capacity of the troposphere. The online chemistry is not interactive with the model radiation and, as a result, the model climate is identical in all CHEM simulations. CAM4 is run for one model year, after spinup, for analysis.

CAM5, with MAM3, is used to model the impacts of different aerosol emissions. Aerosols are set as radiatively and microphysically active in CAM5 in order to capture the aerosol indirect effects. Therefore, the model climate state depends on the initial emissions (in contrast to the CHEM simulations). To smooth out the interannual variability in the climate state, the model is integrated for five years, after 
Table 1. Community Atmosphere Model (CAM) simulations analyzed in this study.

\begin{tabular}{llll}
\hline Name ${ }^{\mathrm{a}}$ & $\begin{array}{l}\text { Fire } \\
\text { Emissions }^{\mathrm{b}}\end{array}$ & $\begin{array}{l}\text { Non-fire } \\
\text { Emissions }\end{array}$ & $\begin{array}{l}\text { Emissions } \\
\text { Year }^{\mathrm{d}}\end{array}$ \\
\hline CHEM simulations $^{\mathrm{e}}$ & & & \\
\hline C_1850_NF & - & ACCMIP & 1850 \\
C_1850_CF & CLM_FIRE_QIAN & ACCMIP & 1850 \\
C_2000_NF & - & ACCMIP & 2000 \\
C_2000_CF & CLM_FIRE_CCSM & ACCMIP & 2000 \\
C_2000_GF & GFEDv2 & ACCMIP & 2000 \\
C_2100_NF & - & RCP 4.5 & 2100 \\
C_2100_CCF & CLM_FIRE_CCSM & RCP 4.5 & 2100 \\
C_2100_ECF & CLM_FIRE_ECHAM & RCP 4.5 & 2100 \\
\hline AERO simulations & & & \\
\hline A_1850_NF & & ACCMIP & 1850 \\
A_1850_CF & - & ACCMIP & 1850 \\
A_2000_NF & CLM_FIRE_QIAN & ACCMIP & 2000 \\
A_2000_CF & - & ACCMIP & 2000 \\
A_2000_GF & GFEDEv2 & ACCMIP & 2000 \\
A_2100_NF & - & RCP 4.5 & 2100 \\
A_2100_CCF & CLM_FIRE_CCSM & RCP 4.5 & 2100 \\
A_2100_ECF & CLM_FIRE_ECHAM & RCP 4.5 & 2100 \\
\hline
\end{tabular}

a The simulation names consist of the first letter of the group name, the emissions year, and an abbreviation for the fire emissions used (NF for no fires, CF for CLM fires and C or E for the future atmospheric forcing).

${ }^{b}$ Fire emissions are derived from the total $\mathrm{C}$ lost due to fires predicted by the CLM simulations noted here and defined in Table 2.

${ }^{c}$ Non-fire emissions for years 1850 and 2000 are taken from the Atmospheric Chemistry and Climate Model Intercomparison Project (ACCMIP) (Lamarque et al., 2010). Future emissions are from Representative Concentration Pathway (RCP) 4.5 (Moss et al., 2010).

d We designate fire and non-fire emissions from the year 1850 as representative of pre-industrial conditions, the year 2000 for present day, and 2100 for the future.

e The CHEM group uses the Community Atmosphere Model (CAM) version 4.9 with the Model for Ozone and Related chemical Tracers (MOZART) version 4 (Emmons et al., 2010) chemistry. All simulations are initialized with climate parameters from the year 2000, including solar input. Year 2000 sea surface temperatures (SSTs) are prescribed, as are aerosol concentrations and greenhouse gas forcing. CHEM simulations are run for one year after a three-year spinup (including one year to spinup the different emissions).

${ }^{f}$ The AERO group uses CAM version 5 with the 3-mode Modal Aerosol Model (Liu et al., 2012). Year 2000 climate parameters are used in all simulations with prescribed SSTs and greenhouse gas forcing. However, in the AERO simulations aerosol concentrations are predicted, not prescribed. AERO simulations are run for five years after a three year spinup (including one year to spinup the different emissions).

spinup, for analysis (similar to Wang et al., 2011; Quass et al., 2009). Chemical oxidant distributions are prescribed.

\subsection{Non-fire emissions}

Non-fire related emissions are given by the Atmospheric Chemistry and Climate Model Intercomparison Project (ACCMIP) (Lamarque et al., 2010) for the three time periods studied here. For future climate we use the ACCMIP emissions for Representative Concentration Pathway (RCP) 4.5 (Moss et al., 2010). The ACCMIP inventory contains emissions of $\mathrm{NMHCs}, \mathrm{NO}, \mathrm{NH}_{3}, \mathrm{SO}_{2}$, and primary $\mathrm{OC}$ and $\mathrm{BC}$ aerosols. Biogenic emissions of isoprene, monoterpenes, $\mathrm{CO}$ and methanol are computed with the Model of Emissions of Gases and Aerosols from Nature (MEGAN) (Guenther et al., 2006) using present-day land cover and $\mathrm{CO}_{2}$ con- centrations. We create pre-industrial biogenic emissions by applying MEGAN to year 1850 leaf area index (LAI) predicted by CLM3, and year $1850 \mathrm{CO}_{2}$ concentrations. The CLM3 LAI is scaled so that the year 2000 isoprene emissions predicted with MEGAN match present day global estimates from Heald et al. (2008). Impacts of fires on biogenic emissions were not included in our emission datasets. Fine mode sea-salt aerosol emissions follow the Martensson et al. (2003) scheme based on surface windspeed and sea surface temperature. Emission of sea-salt particles with geometric diameters greater than 2.8 microns is solely a function of windspeed (Monahan et al., 1986). Mineral dust emission in CAM is based on the Dust Entrainment and Deposition Model (Zender et al., 2003). 
Table 2. Community Land Model (CLM) simulations analyzed in the current study.

\begin{tabular}{lllll}
\hline Name & $\begin{array}{l}\text { Simulation } \\
\text { Years }\end{array}$ & $\begin{array}{l}\text { Atmospheric } \\
\text { Forcing }^{\mathrm{a}}\end{array}$ & $\begin{array}{l}\text { Fire Model } \\
\text { Used }\end{array}$ & $\begin{array}{l}\text { Land-cover }^{\text {Change }} \\
\text { CLM_NOFIRE simulations }^{\mathrm{c}}\end{array}$ \\
& & & & \\
\hline CLM_NOFIRE_QIAN & $1798-2004$ & Qian & None & Hurtt et al. (2006) \\
CLM_NOFIRE_CCSM & $1958-2100$ & CCSM & None & RCP4.5 \\
CLM_NOFIRE_ECHAM & $1958-2100$ & ECHAM & None & RCP4.5 \\
\hline CLM_FIRE simulations ${ }^{\mathrm{d}}$ & & & & \\
\hline CLM_FIRE_QIAN & $1798-2004$ & Qian & Kloster et al. (2010) & Hurtt et al. (2006) \\
CLM_FIRE_CCSM & $1958-2100$ & CCSM & Kloster et al. (2010) & RCP4.5 \\
CLM_FIRE_ECHAM & $1958-2100$ & ECHAM & Kloster et al. (2010) & RCP4.5 \\
\hline
\end{tabular}

a Atmospheric forcing is cycled through the Qian et al. (2006) reanalysis years 1948 to 1972 prior to model year 1948, followed by the reanalysis for years 1948 to 2004 corresponding to the model year, where "Qian" is shown in the table. For future simulations, climate anomalies predicted by the Community Climate System Model (CCSM) (Meehl et al., 2006) or ECHAM5/MPI-OM (ECHAM) (Roeckner et al., 2006) are applied to the Qian et al. (2006) reanalysis that cycled through the years 1948 to 1972.

$\mathrm{b}$ Transient land cover change follows either the Hurtt et al. (2006) timeseries for years 1850 to 2004, or projections for Representative Concentration Pathway (RCP) 4.5 (Hurtt et al., 2011).

${ }^{\mathrm{c}}$ The no-fire simulations are branched at year 1798 from an 850 year spin-up simulation using CLM v3.5 with carbon and nitrogen cycles. Transient atmospheric $\mathrm{CO}_{2}$ concentrations are applied from 1798 through 2100 (SRES A1B projections after year 2000) and transient nitrogen deposition is applied from 1798 through 2000 with year 2000 values used for 2000 to 2100 .

d The CLM_FIRE simulations were taken from Kloster et al. $(2010,2012)$ and use the same general settings as the CLM_NOFIRE simulations.

\subsection{Fire emissions}

\subsubsection{Simulation of fire activity}

Fire emissions are calculated from the Kloster et al. (2010, 2012) CLM3 simulations of global fire area burned from the year 1798 to 2100 . CLM3 simulates land surface processes including heat and water transfer in soils, photosynthesis, interactions between vegetation and atmospheric radiation, urbanized land impacts, and snow pack dynamics (Decker and Zeng, 2009; Sakaguchi and Zeng, 2009; Niu and Yang, 2007; Flanner and Zender, 2005; Flanner et al., 2007; Wang and Zeng, 2009; Lawrence and Slater, 2008, 2009; Oleson et al., 2008b). These simulations used the carbon-nitrogen biogeochemical cycling extension of CLM3 (CN) (Thornton et al., 2007; Thornton et al., 2009). The CN model tracks storage and fluxes of $\mathrm{C}$ and nitrogen $(\mathrm{N})$ between vegetation, soil, and litter pools, and introduces $\mathrm{N}$ limitation on primary production.

CLM3 was forced with air temperature, humidity, wind, air pressure, precipitation, and solar radiation data from the Qian et al. (2006) NCEP/NCAR reanalysis. The year 1948 to 1972 atmospheric forcing data was repeatedly cycled during the model years 1798 through 1972 with the last 25 years corresponding exactly to the reanalysis. After year 1972 and through year 2100 , the same reanalysis dataset was cycled with climate anomalies applied. The anomalies were defined as the difference between monthly mean future projections and the base period (1948-1972) reanalysis. They were developed from three ensemble runs from the coupled climate models ECHAM5/MPI-OM (hereafter ECHAM) (Roeckner et al., 2006) and three runs from the Community Climate
System Model (CCSM) (Meehl et al., 2006) all using the SRES A1B scenario (Nakicenovic, 2000). The global annual mean surface temperature increases by $2.1 \mathrm{~K}$ in the CCSM ensemble mean and $3.4 \mathrm{~K}$ in the ECHAM ensemble mean, with both datasets projecting a $7 \%$ increase in global annual average precipitation between years 2000 and 2100. Transient atmospheric $\mathrm{CO}_{2}$ concentration was also taken from the SRES A1B scenario. $\mathrm{N}$ deposition follows Lamarque et al. (2005) through the year 2004 and was kept constant at present day levels through the year 2100 .

Transient population density and land cover were used from 1850 to 2100 . Population density is needed to model human-caused fire ignition and fire suppression. Land use and land cover changes for 1850 to 2000 follow Hurtt et al. (2006) and were implemented in CLM as plant functional type (PFT) changes (Lawrence et al., 2011). Future land use and land cover changes follow the RCP 4.5 projection (Hurtt et al., 2011). All the RCP land use and land cover change scenarios lead to future decreases in global fire emissions by reducing the available biomass (Kloster et al., 2012). The RCP 4.5 projection leads to the smallest decrease in fire emissions, $5 \%$, compared to the maximum decrease of $30 \%$ for RCP 8.5 by the year 2100 (Kloster et al., 2012).

\subsubsection{C emission from fires}

The total $\mathrm{C}$ lost due to fire, including deforestation fires, is used to estimate global fire emissions. The amount of $\mathrm{C}$ lost in fires, predicted by the Kloster et al. $(2010,2012)$ CLM3 simulations, gradually increases from year 1850 through the 1950s (total increase of about $100 \mathrm{Tg} \mathrm{C} \mathrm{yr}^{-1}$ ), but then decreases from 1950 to 2000 by about $250 \mathrm{Tg} \mathrm{C} \mathrm{yr}^{-1}$ (Fig. 2). 


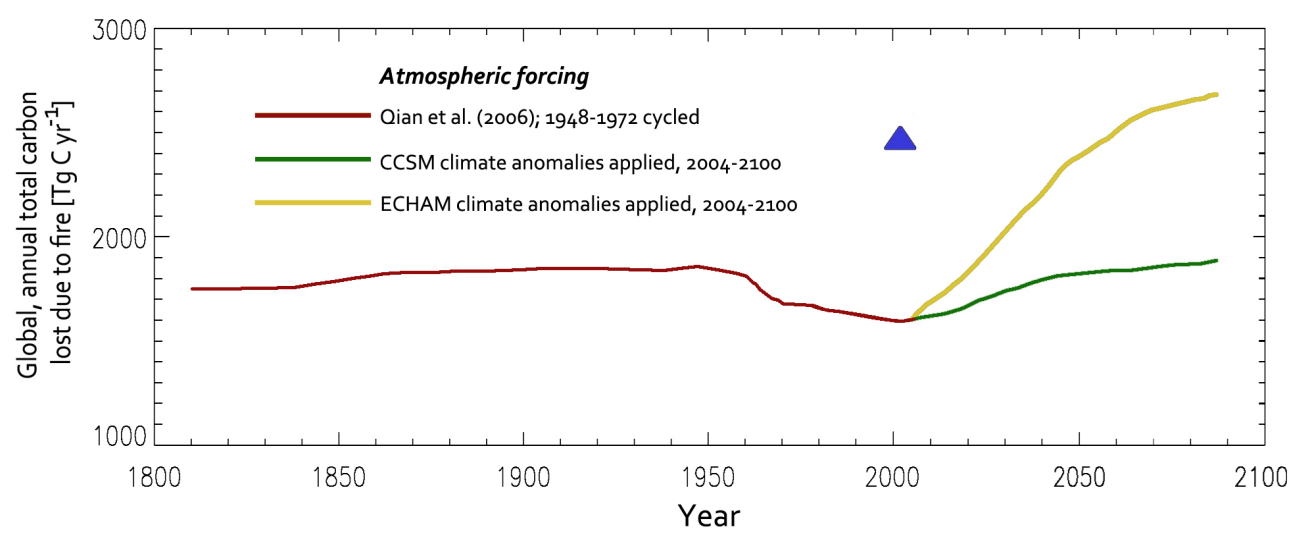

Fig. 2. Timeseries of the total C lost due to fires plotted from the output of the Kloster et al. (2012) Community Land Model (CLM) simulations. The timeseries is smoothed using a 25-yr running average. The 1997 to 2006 annual average value from the GFEDv2 is shown as a blue triangle for comparison.

Future trends depend on the atmospheric forcing, showing a steep increase of $1100 \mathrm{Tg} \mathrm{C} \mathrm{yr}^{-1}$ from year 2000 to 2100 for the ECHAM forcing and an increase of only $300 \mathrm{Tg} \mathrm{C} \mathrm{yr}^{-1}$ with the CCSM forcing. Monthly averages of the C lost in fires are constructed for the pre-industrial, present-day and future cases from years 1845 to 1854 (hereafter 1850), 1997 to 2006 (hereafter 2000) and 2090 to 2099 (hereafter 2100), respectively. For the 1997 to 2006 average we use the CLM3 results with CCSM atmospheric forcing, which is very similar to the results with ECHAM atmospheric forcing for these years (Kloster et al., 2012). Using decadal means diminishes the impact of the interannual variability of fire emissions when a single year is used to drive the model emissions (Lamarque et al., 2010). A future fire emission dataset is compiled for each atmospheric forcing ensemble, CCSM and ECHAM, averaged separately to create two future datasets. In addition, fire emissions estimates from the GFED version 2 (GFEDv2) (van der Werf et al., 2006) are used as a comparison to the present-day CLM3 derived emissions. The GFEDv2 emissions are derived from satellite estimates of area burned and biomass distributions predicted by a biogeochemical model (van der Werf et al., 2006).

Comparisons of the CLM3 C lost from fires to that of the GFEDv2 suggest that the model underestimates the globally averaged $\mathrm{C}$ emissions in the present day (Fig. 2). This bias results in large part from differences in the area burned by Northern Hemisphere tropical fires, between $5^{\circ} \mathrm{N}$ and $15^{\circ} \mathrm{N}$ (Fig. 3a). Furthermore, CLM3 overestimates mid-latitude fire area burned, especially in North America, and does not capture high-latitude fires in the Northern Hemisphere. The model underestimates the amount of $\mathrm{C}$ lost per area burned compared to the GFEDv2 inventory in these regions, as shown in Fig. 3b. This could result partly from the model missing $\mathrm{C}$ emissions from boreal region peatland fires. These fires are not predicted in our CLM3 simulations. According to one estimate, in Canada alone peatland fires emit about
$6 \mathrm{Tg} \mathrm{C} \mathrm{yr}^{-1}$ (Turetsky et al., 2004). Flannigan et al. (2009) note that peatland fire emissions are more sensitive to climate changes since they are not fuel-limited. High latitude aerosol emissions, such as from peatland fires, impact snow surface and land surface albedo changes (Randerson et al., 2006; Flanner et al., 2007). Elsewhere on the globe, the $\mathrm{C}$ lost per area burned from CLM3 and GFEDv2 is similar: this is expected, as during model development the results were compared to GFEDv2 (Kloster et al., 2010). For a full spatial comparison of the model results to GFEDv2, see Kloster et al. (2010).

\subsubsection{Application of emission factors}

The total C lost from fires is converted to emissions of various gas-phase and aerosol species using the emission factors given by Andreae and Merlet (2001) and updated for $\mathrm{CO}_{2}$, $\mathrm{CO}, \mathrm{NO}_{\mathrm{x}}, \mathrm{SO}_{2}$, and $\mathrm{OC}$ and $\mathrm{BC}$ aerosols by Hoelzemann et al. (2004). The emission factors were derived for three major biomes (tropical forest, extratropical forest, and savannah and grassland) for which different burning intensities are characteristic. The area burned for each of these biomes is given in Fig. 3c, with savanna and grasslands broken into three categories also containing extra-tropical shrubs. Here we apply the CLM3 land cover classification to the GFEDv2 area burned product. A larger fraction of the area burned in the GFEDv2 inventory was grassland (particularly tropical grassland) compared to CLM3, which predicted more midlatitude forest area burned than GFEDv2 (Fig. 3a).

Emission factors are given as the mass emitted per unit mass of dry matter burned. We assume the $\mathrm{C}$ content of the burned matter is equal to the total mass of the $\mathrm{C}$ emitted as $\mathrm{CO}_{2}$ and $\mathrm{CO}$ per unit mass of dry matter (Andreae and Merlet, 2001). Other C-containing species do not have an appreciable effect on the total $\mathrm{C}$ emitted. The resulting biomedependent $\mathrm{C}$ contents ( $47 \%$ to $48 \%$ ) are comparable to the 

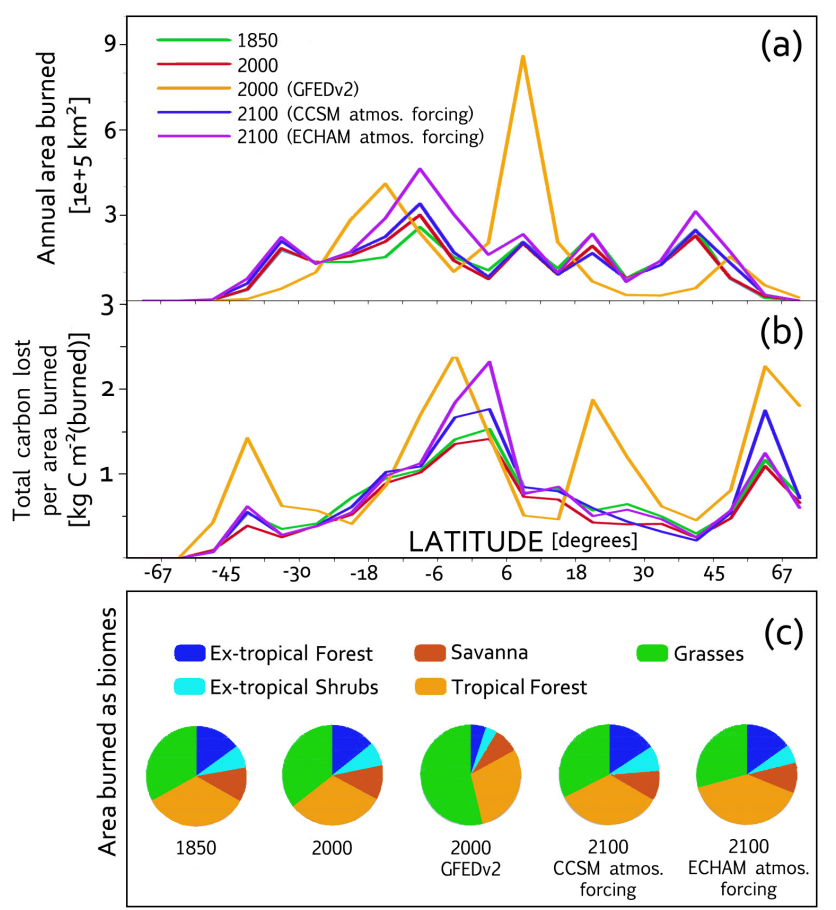

Fig. 3. A plot by latitude of (a) the annual total area burned for each 10-yr emissions period and (b) the amount of $\mathrm{C}$ released per area burned, and (c) a breakdown of the global annual average area burned into biomes defined by the CLM3 PFTs database for the respective time periods. Line and pie graph labels indicate the representative year and atmospheric forcing (for future simulations) for the CLM3 modeled fires, and, where labeled, the GFEDv2 present day fires. Note that the latitude bands each contain approximately the same surface area for better comparison of the total area burned across latitudes.

constant C content value of $45 \%$ used by van der Werf et al. (2006).

CLM3 simulates the area coverage of 16 PFTs. These are classified into the three major biomes as defined by Andreae and Merlet (2001). All grass and shrub PFTs are considered savanna and grassland, temperate and boreal forest PFTs are considered extratropical forests, and the remaining forest PFTs are aggregated into the tropical forest biome. The $\mathrm{C}$ lost from fires for each PFT is converted to dry matter using the $\mathrm{C}$ content and multiplied by the emission factor for 22 different gas and aerosol species. These are $\mathrm{CO}_{2}, \mathrm{CO}, \mathrm{CH}_{4}, 12$ additional $\mathrm{NMHCs}, \mathrm{SO}_{2}, \mathrm{NH}_{3}, \mathrm{NO}$, and $\mathrm{BC}$ and $\mathrm{OC}$ aerosol. The aerosol species are split into hydrophobic and hydrophilic categories according to Emmons et al. (2010).

\subsubsection{Treatment of $\mathbf{N}$ loss from fires}

Total $\mathrm{N}$ lost due to fires is also predicted by CLM3. We compute the global, annual $\mathrm{N}$ lost due to fires as $29 \mathrm{Tg} \mathrm{N}^{-1}$, $26 \mathrm{Tg} \mathrm{N} \mathrm{yr}^{-1}$, and $37 \mathrm{Tg} \mathrm{N} \mathrm{yr}^{-1}$ for 1850, 2000 and 2100 (averaged between the two future datasets), respectively. These values are somewhat larger than a recent global estimate from the GFEDv2 of $22.2 \mathrm{Tg} \mathrm{N} \mathrm{yr}^{-1}$ (Chen et al., 2010).

The speciation of the lost $\mathrm{N}$ also follows the Andreae and Merlet (2001) emission factors, meaning emission of $\mathrm{N}$ containing species is proportional to the $\mathrm{C}$ content of burned matter, not the $\mathrm{N}$ content. Of the emitted $\mathrm{N}, 25$ to $30 \%$ is released as $\mathrm{NH}_{3}$ or $\mathrm{NO}_{\mathrm{x}}$ in all time periods. An additional fraction is emitted as molecular $\mathrm{N}\left(\mathrm{N}_{2}\right)$ (Crutzen and Andreae, 1990). Andreae and Merlet (2001) estimate $30 \%$ to $40 \%$ of $\mathrm{N}$ lost from fires is emitted as $\mathrm{N}_{2}$, but Chen et al. (2010) suggest a value of about $50 \%$ with higher percentages in ecosystems with more complete combustion. Adding together contributions from $\mathrm{NH}_{3}, \mathrm{NO}_{\mathrm{x}}$ and $\mathrm{N}_{2}$ using the C-based emission factors, and after small amounts of trace gases $\mathrm{N}_{2} \mathrm{O}$ and $\mathrm{HCN}$ are considered, there is still a portion of the $\mathrm{N}$ lost from fires, about 20 to $25 \%$, that is not accounted for in our emissions estimates.

\subsubsection{Aerosol emissions}

All fire emissions are released into the lowest CAM level for the CHEM and AERO simulations. This follows the recent results of Tosca et al. (2011) and val Martin et al. (2010) that show most fires' emissions remain within the planetary boundary layer. A variable injection height for emissions was found to be a minor factor for predicting the distribution of smoke plumes in the western United States (Mao et al., 2011), and in southeast Asia (Zhang et al., 2011).

Observations of aerosol optical depth (AOD) from the Aerosol Robotic Network (AERONET) have shown that the GFEDv2 inventory underestimates emissions of aerosols from fires in the tropics when applied in modeling studies (Matichuk et al., 2008; Chin et al., 2009; Tosca et al., 2010; Johnston et al., 2012). Koch et al. (2009) note that most models underestimate BC concentrations in biomass burning regions because of problems with the emission factors or with the estimates of the optical properties of smoke. We scale aerosol emissions from CLM3 and GFEDv2 fires in several regions following the approach of Johnston et al. (2012) to account for this apparent bias (Appendix A).

\section{4 "No-fire" CLM3 simulations}

We repeat the Kloster et al. (2010, 2012) CLM3 simulations with fire activity switched off to understand the role of fires in modifying atmospheric $\mathrm{CO}_{2}$ levels (details in Table 2). The spin-up procedure for these simulations follows Kloster et al. (2010). CLM3 begins with a non-zero carbon pool state and is integrated until the global average net ecosystem exchange (NEE) of carbon averaged over a 25 -year cycle of atmospheric forcing is less than $\pm 0.05 \mathrm{Pg} \mathrm{C} \mathrm{yr}^{-1}$ (850 model years in this case). This is slightly less rigorous than the level used by Mahowald et al. (2011a) of $\pm 0.01 \mathrm{Pg} \mathrm{C} \mathrm{yr}^{-1}$ but is consistent with Kloster et al. (2012). Vegetation growth is 

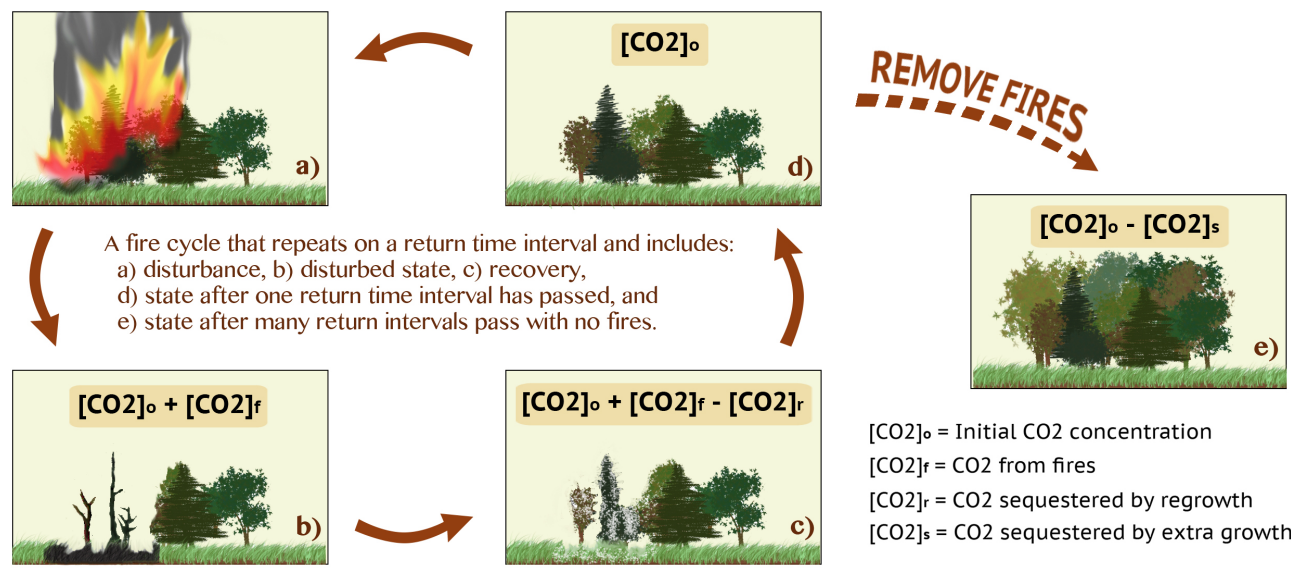

Fig. 4. A representation of a fire cycle with associated $\mathrm{CO}_{2}$ changes, and an illustration of the same ecosystem with fires removed.

limited by nutrient and water availability as well as gap mortality.

The transient run is branched from the end of the spin-up run starting at the year 1798 with pre-industrial $\mathrm{CO}_{2}$ and PFT distribution. After 1798 the model setup uses the transient $\mathrm{CO}_{2}$, atmospheric forcing, and land use change described in Sect. 2.3.1. Changes in $\mathrm{CO}_{2}$ from removing fires do not feedback into the CLM3 runs. We chose one ensemble member from the CCSM and ECHAM groups for climate forcing, noting that the differences in fire emissions between ensemble members are small (Kloster et al., 2012).

\subsection{RF calculations}

The estimates for the RF of $\mathrm{CO}_{2}, \mathrm{CH}_{4}$ and $\mathrm{N}_{2} \mathrm{O}$ follow the IPCC definition of adjusted radiative forcing, $F_{\mathrm{a}}$ (Ramaswamy et al., 2001), where $F_{\mathrm{a}}$ is the change in radiative flux at the tropopause after allowing for stratospheric temperature adjustment. As stated in the introduction, we define RF relative to a no-fire state rather than a pre-industrial state. We calculate the change in radiative flux due to $\mathrm{O}_{3}$ from fires at the tropopause, which is better defined as an instantaneous forcing $\left(F_{\mathrm{i}}\right)$. Hansen et al. (2005) report global climate simulations for the time period 1880 to 2000 for which the ratio of $F_{\mathrm{i}}: F_{\mathrm{a}}=0.83$ for tropospheric $\mathrm{O}_{3}$, suggesting that $F_{\mathrm{i}}$ for $\mathrm{O}_{3}$ from fires in this study is likely to be somewhat smaller but roughly equivalent to $F_{\mathrm{a}}$. For aerosols, the difference between the radiative fluxes at the tropopause and the top of the atmosphere (TOA) is considered small and the stratospheric adjustment is minimal (Forster et al., 2007). Therefore the TOA RF computed in this study for aerosols can be compared to the $F_{\mathrm{a}}$ of the other forcings. For albedo changes we also report a TOA RF. The difference between $F_{\mathrm{i}}$ and $F_{\mathrm{a}}$ for surface albedo changes is considered negligible (e.g. Hansen et al., 2005; Randerson et al., 2006), but it should be noted that differences in radiative fluxes between TOA and the tropopause are not accounted for here.

\subsubsection{Carbon dioxide}

Global $\mathrm{CO}_{2}$ emissions from fires in our CLM3 simulations range from $1.3 \mathrm{Pg} \mathrm{C} \mathrm{yr}^{-1}$ for present day emissions to $2.4 \mathrm{Pg} \mathrm{C} \mathrm{yr}^{-1}$ for the future trajectory with ECHAM atmospheric forcing. It follows that fire emissions of $\mathrm{CO}_{2}$, as a greenhouse gas, will lead to a positive RF. However, in the case of fires, $\mathrm{CO}_{2}$ emissions may be offset by the regrowth of vegetation in the burned area, which sequesters the lost $\mathrm{C}$ on time scales from a few years to many decades. It is often assumed that fires are followed by regrowth of the same vegetation types and are neither a source nor a sink for $\mathrm{CO}_{2}$ (e.g. Bowman et al., 2009). In CLM3 for example, the PFT distribution is not allowed to change due to fire disturbance. However, climate-induced changes to fire frequency will alter landscape-mean $\mathrm{C}$ stocks and affect atmospheric $\mathrm{CO}_{2}$.

Here we examine the redistribution of $\mathrm{C}$ between land, atmosphere and ocean pools that occurs because of all fire activity. The difference in terrestrial $\mathrm{C}$ storage caused by fires is predicted by comparing the CLM3 simulations with fires to the simulations without fires. The $\mathrm{C}$ storage difference accounts for the $\mathrm{CO}_{2}$ sequestered by the regrowth of vegetation in fire-affected areas. This is illustrated in Fig. 4 where the $\mathrm{CO}_{2}$ sequestered when fires are removed is marked as $\left[\mathrm{CO}_{2}\right]_{\mathrm{s}}$ and represents figuratively the amount of $\mathrm{CO}_{2}$ that remains in the atmosphere because of fires.

The removal rate of $\mathrm{CO}_{2}$ from the atmosphere is buffered by physical processes that are themselves dependent on the $\mathrm{C}$ concentrations in the atmosphere and ocean (Archer et al., 2009). Therefore, to estimate atmospheric $\mathrm{CO}_{2}$ concentration for a pre-industrial time period without fires, we compute a new steady-state land-atmosphere-ocean $\mathrm{C}$ partitioning that accounts for the change in land $\mathrm{C}$ storage due to fires predicted by CLM3. This steady-state can be imagined to have taken place over a long enough timescale for the three main C pools to reach equilibrium. Goodwin et al. (2007) introduce an analytical expression for the change in atmospheric $\mathrm{CO}_{2}$ 
at equilibrium with the ocean and land, given a perturbation to an initial $\mathrm{C}$ pool partitioning:

$P_{\mathrm{CO}_{2}}=P_{\mathrm{i}} e^{\frac{\Delta \Sigma C}{I_{\mathrm{B}}}}$

where $P_{\mathrm{CO}_{2}}$ and $P_{\mathrm{i}}$ are the new steady-state and initial atmospheric $\mathrm{CO}_{2}$ concentrations, respectively, $\Delta \Sigma \mathrm{C}$ is the total change in $\mathrm{C}$ stored on land, and $I_{\mathrm{B}}$ is a steady-state, preindustrial total C inventory for which we use $I_{\mathrm{B}}=3100 \mathrm{GtC}$ as suggested by Goodwin et al. (2007). The new concentration can be considered the $\left[\mathrm{CO}_{2}\right]_{\mathrm{s}}$ (from Fig. 4), or the amount of extra $\mathrm{C}$ in the steady-state, pre-industrial atmosphere due to global fire activity.

To estimate the concentration of $\mathrm{CO}_{2}$ in the atmosphere because of fire emissions that took place against a background of changing anthropogenic $\mathrm{C}$ emissions (i.e. 1850 through 2100), we use a pulse response approach for atmosphere-ocean $\mathrm{C}$ equilibrium, similar to Randerson et al. (2006) and O'Halloran et al. (2012). The details of this analysis are given in Appendix B1.

\subsubsection{Methane}

Fires emit a small amount of $\mathrm{CH}_{4}$ directly into the atmosphere but also affect the $\mathrm{CH}_{4}$ mixing ratio by modifying the concentrations of atmospheric oxidants. The major atmospheric sink for $\mathrm{CH}_{4}$ is reaction with $\mathrm{OH}$, part of the "primary natural mode" which describes the time-scale of interactions between $\mathrm{CH}_{4}, \mathrm{CO}$ and $\mathrm{OH}$ (Wild and Prather, 2000). The primary mode accounts for the long-term radiative effects (12 to 15 years) of a perturbation to the tropospheric chemical system (Wild et al., 2001). Previous modeling work by Naik et al. (2007) showed that fire emissions can lead to both increases and decreases in $[\mathrm{OH}]$ depending on the relative amounts of $\mathrm{NO}_{\mathrm{x}}$ and $\mathrm{CO}+\mathrm{NMHC}$ emitted. Increased emissions of $\mathrm{NO}_{\mathrm{x}}$, such as within a smoke plume, can enhance the production of $\mathrm{O}_{3}$, which produces $\mathrm{OH}$ by photolysis (Naik et al., 2005). The enhanced production of $\mathrm{OH}$ leads to destruction of tropospheric $\mathrm{CH}_{4}$ and will decrease the $\mathrm{CH}_{4}$ lifetime. In contrast, $\mathrm{OH}$ is removed from the atmosphere through oxidation of $\mathrm{CO}$ and NMHC for which fires are a major source. This acts to lengthen the $\mathrm{CH}_{4}$ lifetime, counteracting to some extent the effect of increased $\mathrm{NO}_{\mathrm{x}}$.

The global mean lifetime of $\mathrm{CH}_{4}$ in the present-day troposphere with respect to reaction with $\mathrm{OH}$ is estimated to be between about 8 to 10 years (Fuglestvedt et al., 1999; Dentener et al., 2005). Due to this long lifetime in the troposphere, the $\mathrm{CH}_{4} \mathrm{RF}$ cannot be explicitly calculated from a single year model simulation. Instead, a change in $[\mathrm{OH}]$ (assumed to be the dominant sink for $\mathrm{CH}_{4}$ ) is used to compute a new $\mathrm{CH}_{4}$ lifetime from which a "steady-state" $\left[\mathrm{CH}_{4}\right]$ and associated RF can be estimated (Fuglestvedt et al., 1999). Details of this calculation are given in Appendix B2.

\subsubsection{Tropospheric ozone}

Ozone is not emitted directly from fires but its concentration in the troposphere is often enhanced by the $\mathrm{O}_{3}$ precursor gases in smoke (Pfister et al., 2008). Fire emissions consist of important components in the photochemical production and loss of $\mathrm{O}_{3}$ (i.e. $\mathrm{CO}, \mathrm{NMHCs}$, and $\mathrm{NO}_{\mathrm{x}}$ ). Pfister et al. (2006) modeled plume transport from boreal North American fires for the summer of 2004 and found enhancements of the lower tropospheric $\mathrm{O}_{3}$ burden of about $10 \%$ over Alaska and Canada. Production of $\mathrm{O}_{3}$ within smoke plumes can continue for days and occur in distant locations relative to the fire. Real et al. (2007) simulated a net production of up to 22 ppbv $\mathrm{O}_{3}$ in smoke from Alaskan fires during its transport to Europe.

The direct influence of fires on $\mathrm{O}_{3}$ concentration through the emission of short-lived precursors (NMHCs and $\mathrm{NO}_{\mathrm{x}}$ ) has been called the "short-lived" $\mathrm{RF}$ of $\mathrm{O}_{3}$ by Naik et al. (2005). To assess the global mean RF due to short-lived tropospheric $\mathrm{O}_{3}$ from fires in our study, the CAM4 radiation package was run offline using the Parallel Offline Radiative Transfer (PORT) tool for each CHEM simulation. PORT applies the CAM radiative transfer scheme to a time-slice of the atmospheric state.

Radiative transfer calculations are carried out with PORT for the instantaneous model atmospheric state at 36.5-h intervals. In this way, the offline radiation diagnostics are computed for the entire diurnal cycle every 48 model days. The calculations are run a second time with $\mathrm{O}_{3}$ removed below the instantaneous model-defined chemical tropopause to estimate the net radiative flux of tropospheric $\mathrm{O}_{3}$. The contribution from fires is defined as the difference in tropospheric $\mathrm{O}_{3} \mathrm{RF}$ between the CAM "fire" and "no-fire" simulations.

Changes in tropospheric $\mathrm{O}_{3}$ also perturb the primary mode $\mathrm{CH}_{4}$ chemistry by acting as a source for $\mathrm{OH}$ (Naik et al., 2005 ; 2007). $\mathrm{As}_{\mathrm{CH}_{4}}$ responds to changes in $\mathrm{OH}$, the production of peroxy radical concentrations is modified, which then feeds back onto the $\mathrm{O}_{3}$ concentration. The primary mode response in $\mathrm{O}_{3}$ can be approximated by the following expression from Naik et al. (2005):

$\left(\Delta \mathrm{O}_{3}\right)_{\text {primary }}=\frac{\Delta\left[\mathrm{CH}_{4}\right]}{\mathrm{CH}_{4}} \cdot \frac{0.64}{0.1} \mathrm{DU}$

The column $\mathrm{O}_{3}$ response of 0.64 Dobson Units (DU) for a $10 \%$ change in $\mathrm{CH}_{4}$ was approximated from model results (Prather et al., 2001). The RF of the primary mode response is estimated with the recommended value of $\mathrm{O}_{3}$ forcing per DU from Forster et al. (2007) of $0.032+/-0.006 \mathrm{~W} \mathrm{~m}^{-2}$ $\mathrm{DU}^{-1}$.

\subsubsection{Nitrous oxide}

Fire emissions of $\mathrm{N}_{2} \mathrm{O}$, computed from the Andreae and Merlet (2001) emission factor, contribute between $2 \%$ to $5 \%$ of global $\mathrm{N}_{2} \mathrm{O}$ emissions for each time period. The 
present-day value for global fire emissions of $\mathrm{N}_{2} \mathrm{O}$ from CLM3 $\left(0.4 \mathrm{Tg} \mathrm{N}\left(\mathrm{N}_{2} \mathrm{O}\right) \mathrm{yr}^{-1}\right)$ is slightly below the range of previous estimates, 0.5 to $1 \mathrm{Tg} \mathrm{N}\left(\mathrm{N}_{2} \mathrm{O}\right) \mathrm{yr}^{-1}$ (Cofer et al., 1991; Ramaswamy et al., 2001; Syakila and Kroeze, 2011).

As with $\mathrm{CH}_{4}, \mathrm{~N}_{2} \mathrm{O}$ is a long-lived greenhouse gas. The radiative effects of a perturbation to $\mathrm{N}_{2} \mathrm{O}$ concentrations will last for well over 100 years and cannot be calculated from a one year model integration. Therefore, to determine the contribution of fires to $\mathrm{N}_{2} \mathrm{O}$ concentrations we use a simple atmospheric box model (Appendix B3). The box model assumes that the change in $\mathrm{N}_{2} \mathrm{O}$ concentration with time equals the difference between $\mathrm{N}_{2} \mathrm{O}$ emissions and $\mathrm{N}_{2} \mathrm{O}$ loss in the stratosphere. We estimate the lifetime of $\mathrm{N}_{2} \mathrm{O}$ for the case with all emissions, and use these parameters to estimate a lifetime when fire emissions of $\mathrm{N}_{2} \mathrm{O}$ are removed.

\subsubsection{Aerosols}

Particle emissions from fires contain mainly carbonaceous material with minor contributions from dust and inorganic salts. Globally, fires account for 55 to $60 \%$ of primary OC and BC aerosol emissions (Mahowald et al., 2011b). OC and $\mathrm{BC}$ scatter and absorb shortwave radiation leading to partially canceling radiative effects. The sum of these effects partly depends on the albedo of the underlying surface, which can include clouds. The cloud fraction and cloud heights are particularly important over the ocean where they introduce a highly reflective surface over a strong absorbing surface (Sakaeda et al., 2011).

To compute the direct effect of fire aerosols in this study we ran online radiation diagnostics during the AERO simulations for which radiative fluxes are calculated with and without aerosol effects. The direct effect RF is defined here as the difference in the change in TOA shortwave flux due to aerosol scattering and absorption that arises from the different emissions (fire against no-fire). This forcing is assessed for all-sky and clear-sky conditions.

Aerosols also impact radiative transfer indirectly by their effects on clouds. Acting as nuclei for cloud droplets and ice crystals, aerosols affect the sizes of the cloud particles leading to changes in the cloud albedo, know as the first indirect aerosol effect. Lohmann and Feichter (2005) list several other indirect effects of aerosols including impacts on cloud lifetime and feedbacks onto mixed-phase clouds. Moreover, absorbing aerosols add heat to the atmosphere and change the vertical temperature profile, affecting the cloud cover and cloud liquid water path. This is known as the semidirect effect since it occurs as a result of the direct effect (Lohmann and Feichter, 2005). It has been shown that BC aerosols, emitted in large quantities by fires, can impose a semi-direct effect that is of similar magnitude to the direct effect (Sakaeda et al., 2011), but the magnitude and even the sign of the forcing is strongly dependent on the affected cloud regime and the height of the absorbing aerosol layer (Koch and Del Genio, 2010).
We define the indirect effect of fire aerosols as the change in total cloud forcing (TCF) between the fire and no-fire aerosol simulations, where $\mathrm{TCF}=$ shortwave cloud forcing (SWCF) + longwave cloud forcing (LWCF). The TCF is assessed at the TOA after removing direct interaction between aerosols and radiation using the online radiation diagnostics. The shortwave portion of this quantity is roughly equivalent to the residual aerosol forcing after the direct effect has been removed. In other words, the indirect effects can be defined here as the total shortwave aerosol forcing minus the direct effect, and finally, with longwave cloud forcing added in. This definition is not equivalent to the first indirect effect as defined by the IPCC because it includes additional effects such as the cloud lifetime effect, and the semi-direct effect of absorbing aerosols. It is in this sense, however, representative of the total impact of fire aerosols.

The aerosol effects can be expressed by three simple relationships for shortwave forcing:

TOTAL AEROSOL EFFECT $=\Delta\left(\mathrm{SNF}_{\mathrm{A}}\right)$ DIRECT AEROSOL EFFECT $=\Delta\left(\mathrm{SNF}_{\mathrm{A}}-\mathrm{SNF}_{\mathrm{N}}\right)$

INDIRECT AEROSOL EFFECTS (Shortwave)

$$
=\Delta\left(\mathrm{SNF}_{\mathrm{N}}\right) \approx \Delta\left(\mathrm{SWCF}_{\mathrm{N}}\right)
$$

Here SNF stands for the net TOA shortwave flux, $\Delta$ represents the difference in the radiative flux expression between the simulation with fire aerosols and the simulation without fire aerosols, and the subscripts indicate the flux was diagnosed with direct aerosol effects, A, and without direct aerosol effects, $\mathrm{N}$.

\subsubsection{Albedo}

The lifetime of aerosols in the atmosphere is on the order of days, after which they are removed either by dry or wet deposition. When aerosols are deposited onto snow surfaces they can change its properties, impacting the albedo and even the melting rate of the snow (Flanner et al., 2007). The role of $\mathrm{BC}$ is particularly important because of its light-absorbing properties (Stohl, 2007).

The Snow, Ice, and Aerosol Radiative (SNICAR) model (Flanner and Zender, 2005; 2006) was run online in CAM5 to simulate changes in the RF of the snow surface due to fire aerosol deposition. Note that this analysis considers deposition of aerosols onto snow and ice surfaces over land but not over sea. The RF from deposition onto sea-ice is thought to be less important than deposition on snow/ice over land (Flanner et al., 2007), but if included, this may have increased the magnitude of our RF estimates.

Fires also have a direct impact on the albedo of the land surface by removing or altering vegetation cover, charring the surface, and in the case of forests, by exposing underlying surfaces with different albedos (grasses, snow, etc.). While extreme local changes in albedo have been observed, the impact will be greatest in high latitudes and forested areas 


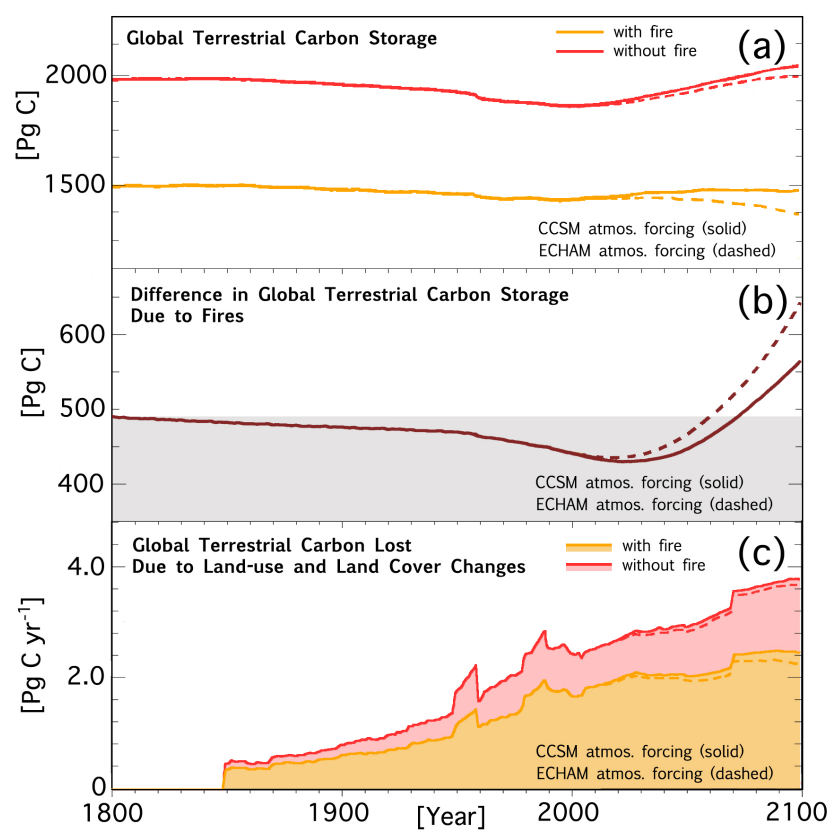

Fig. 5. Timeseries of (a) the total C stored in terrestrial ecosystems, (b) the difference in total $\mathrm{C}$ stored in terrestrial ecosystems between the CLM_NOFIRE and CLM_FIRE simulation sets (see Table 2), and (c) the total $\mathrm{C}$ lost due to land use and land cover changes, plotted for the CLM_NOFIRE simulations (red; (a) and (c)) and the CLM_FIRE simulations (orange; (a) and (c)). The shaded region in (b) indicates when the change in carbon storage due to removing fires is less than the initial (year 1798) value. C lost from land use and land cover change is defined as the $\mathrm{C}$ flux to the atmosphere from recategorization of land cover (for example, from forest to crops) and wood harvesting.

(Randerson et al., 2006). Here we use our model estimates of fire area burned and post-fire land surface albedo change trajectories compiled from the literature to estimate the RF of the albedo changes and the change in the RF through time (Appendix B4).

\section{Results}

\section{1 $\mathrm{CO}_{2}$ radiative forcing}

When fires are removed from the CLM3 model long-term integration, an additional $\sim 500 \mathrm{PgC}$ is stored in the land C pools (Fig. 5a and b, at year 1800), with contributions from increased storage in coarse woody debris $(+31 \%)$, litter $(+17 \%)$, and live vegetation $(+53 \%)$. This pre-industrial increase in land $\mathrm{C}$ storage corresponds to an equilibrium atmospheric $\mathrm{CO}_{2}$ concentration that has decreased by $41 \mathrm{ppm}$. From this analysis we compute a $\mathrm{RF}$ of $\mathrm{CO}_{2}$ from fire activity of $0.83 \mathrm{~W} \mathrm{~m}^{-2}$. This forcing illustrates the important role fire disturbance plays in the global $\mathrm{C}$ cycle.

In the 19th and 20th centuries, $63 \mathrm{PgC}$ was lost from the terrestrial $\mathrm{C}$ pools when fire activity was excluded from CLM3 (Fig. 5b). This results from land use related PFT changes (Hurtt et al., 2006) that are applied to the CLM_FIRE_QIAN and CLM_NOFIRE_QIAN simulations starting in the year 1850. As noted by Houghton et al. (1999) and Kloster et al. (2010), fires maintain lower C storage in vegetation, which can become a weaker $\mathrm{C}$ source if land use related $\mathrm{C}$ loss occurs (such as deforestation or wood harvest). This is also the case in our simulations in which greater amounts of terrestrial $\mathrm{C}$ are lost to the atmosphere by land use and land cover change without fires (Fig. 5c). Therefore the change in $\mathrm{RF}$ of $\mathrm{CO}_{2}$ from fires between 1850 and 2000 is negative, $\mathrm{RF}=-0.21 \mathrm{~W} \mathrm{~m}^{-2}$. This means since preindustrial times fires have reduced the amount of $\mathrm{C}$ available to be lost to the atmosphere through land use changes that remove terrestrial $\mathrm{C}$.

The difference in $\mathrm{C}$ lost from land use and land cover change between the fire and no-fire simulations increases steadily after the year 2000 (Fig. 5c). In addition, atmospheric $\mathrm{CO}_{2}$ and temperatures increase more rapidly after the year $2000\left(\left[\mathrm{CO}_{2}\right]\right.$ and global annual mean surface temperature increase from $365 \mathrm{ppm}, 288 \mathrm{~K}$ to $706 \mathrm{ppm}, 290.7 \mathrm{~K}$ between 2000 to 2100). With increasing temperatures, mobilization of soil $\mathrm{N}$ increases and plants are less $\mathrm{N}$-limited, as also shown by Thornton et al. (2009). This, combined with greater atmospheric $\mathrm{CO}_{2}$, leads to enhanced gross primary production, and accumulation of terrestrial $\mathrm{C}$, in all our CLM3 simulations from years 2000 to 2050 (Fig. 5b). However, $\mathrm{C}$ accumulates at a lower rate with fire activity. Fires impose consistent losses of $\mathrm{C}$ and $\mathrm{N}$ from vegetation (the fire simulation stores about $40 \%$ less $C$ in vegetation in 2000), which suppresses production. This effect is especially evident in Fig. 5a in which the global terrestrial C storage stops increasing or decreases (depending on the atmospheric forcing used) at year 2050 when fires are included, but continues to increase without fires included.

The change in the RF of $\mathrm{CO}_{2}$ from fires between 1850 and 2100 is $-0.08 \mathrm{~W} \mathrm{~m}^{-2}$ with the CCSM atmospheric forcing and $+0.08 \mathrm{~W} \mathrm{~m}^{-2}$ with the ECHAM atmospheric forcing. While the terrestrial C storage increases by over $100 \mathrm{Pg} \mathrm{C}$ from year 2000 to 2100 without fires, the increased background $\mathrm{CO}_{2}$ concentrations dampen the impact on the RF by the saturation effect. The magnitude and sign of the RF are also likely to be dependent on the choice of future land use trajectory. RCPs 6.0 and 8.5 project higher global wood harvest rates compared to RCP 2.6 or RCP 4.5. This reduces global biomass and contributes to a decrease in CLM3 fire emissions in the future by $30 \%$ over RCP 4.5 (Kloster et al., 2012). If these alternative high harvest scenarios were applied to the current study, we would expect the change in the $\mathrm{CO}_{2} \mathrm{RF}$ due to fires from year 1850 to 2100 to decrease.

\section{2 $\mathrm{CH}_{4}, \mathrm{O}_{3}$ and $\mathrm{N}_{2} \mathrm{O}$ radiative forcing}

The magnitude of the RF due to $\mathrm{CH}_{4}$ from fires is between 0.04 and $0.09 \mathrm{~W} \mathrm{~m}^{-2}$ for all simulations (Table 3). 
Table 3. Global annual average chemical quantities for all simulations in the CHEM group (definition of simulation names are in Table 1).

\begin{tabular}{|c|c|c|c|c|c|c|c|c|}
\hline \multirow[b]{2}{*}{ Simulation } & \multicolumn{2}{|c|}{$\left[\mathrm{O}_{3}\right]$} & \multicolumn{2}{|c|}{$\mathrm{O}_{3}$ Radiative Effect } & \multirow{2}{*}{$\begin{array}{l}{[\mathrm{OH}]} \\
\text { Column } \\
(\text { molecules } \\
\left.\mathrm{cm}^{-3} \times 10^{6}\right)\end{array}$} & \multirow{2}{*}{$\begin{array}{l}\tau\left(\mathrm{CH}_{4}\right)^{\mathrm{a}} \\
\text { (years) }\end{array}$} & \multicolumn{2}{|c|}{$\mathrm{CH}_{4}$ Radiative Effect } \\
\hline & $\begin{array}{l}\text { Surface } \\
\text { (ppbv) }\end{array}$ & $\begin{array}{l}\text { Column } \\
\text { (Dobson } \\
\text { Units) }\end{array}$ & $\begin{array}{r}\text { Short-lived } \\
\text { (V }\end{array}$ & $\begin{array}{l}\text { Primary-mode } \\
\mathrm{m}^{-2} \text { ) }\end{array}$ & & & Direct & $\begin{array}{r}\text { Total } \\
\left(\mathrm{W} \mathrm{m}^{-2}\right)\end{array}$ \\
\hline C_1850_NF & 14 & 16 & - & - & 0.70 & 11.4 & - & - \\
\hline C_1850_CF & 15 & 17 & 0.05 & 0.02 & 0.71 & 11.2 & 0.06 & 0.06 \\
\hline C_2000_NF & 26 & 27 & - & - & 1.0 & 8.8 & - & - \\
\hline C_2000_CF & 27 & 28 & 0.02 & 0.01 & 0.96 & 9.1 & 0.02 & 0.04 \\
\hline C_2000_GF & 26 & 27 & 0.00 & 0.03 & 0.89 & 9.7 & 0.03 & 0.09 \\
\hline C_2100_NF & 23 & 25 & - & - & 1.0 & 8.4 & - & - \\
\hline C_2100_CCF & 24 & 26 & 0.02 & 0.02 & 0.94 & 8.8 & 0.03 & 0.05 \\
\hline C_2100_ECF & 24 & 26 & 0.03 & 0.03 & 0.90 & 9.0 & 0.04 & 0.08 \\
\hline
\end{tabular}

a The $\mathrm{CH}_{4}$ lifetime, $\tau$, was computed with respect to reaction with $\mathrm{OH}$.

b Column is defined here as being from the Earth's surface to the chemical tropopause. The chemical tropopause is defined as the lowest level for which the $\mathrm{O}_{3}$ mixing ratio exceeds 150 ppbv.

c Here column is defined as the layer between the Earth's surface and $200 \mathrm{hPa}$.

Present day and future fires cause a reduction in global $\mathrm{OH}$ of $4 \%$ to $10 \%$, indicating that on average the $\mathrm{OH}$ sink introduced by fires (CO and NHMC emissions) dominates the $\mathrm{OH}$ source $\left(\mathrm{O}_{3}\right.$ production $)$ for these time periods. $\mathrm{CH}_{4}$ lifetimes subsequently increase due to fires (Table 3), leading to positive RFs of 0.02 (simulation C_2000_CF; defined in Table 1) and 0.06 (simulation C_2000_GF) $\mathrm{W} \mathrm{m}^{-2}$ for the present day, and 0.02 (simulation C_2100_CCF) and 0.04 (simulation C_2100_ECF) $\mathrm{W} \mathrm{m}^{-2}$ for the year 2100. The RFs of direct $\mathrm{CH}_{4}$ emissions vary between 0.02 and $0.04 \mathrm{~W} \mathrm{~m}^{-2}$ for years 2000 and 2100.

In contrast, pre-industrial fires cause a $1 \%$ increase in global average $\mathrm{OH}$, leading to a $0.2 \mathrm{y}$ decrease in $\mathrm{CH}_{4}$ lifetime. The increase in $\mathrm{OH}$ can be attributed to proportionally greater $\mathrm{O}_{3}$ production due to fires in year 1850 (7\% increase) compared to the year 2000 ( 0 to $2 \%$ increase). Studies have shown that the addition of $\mathrm{NO}_{\mathrm{x}}$ to a background of reduced concentrations of $\mathrm{NO}_{\mathrm{x}}$ and $\mathrm{NMHCs}$, such as the preindustrial environment, results in proportionally larger production of $\mathrm{O}_{3}$ (e.g. Naik et al., 2005; Pfister et al., 2008). The enhanced $\mathrm{O}_{3}$ production acts as a source for $\mathrm{OH}$ that counteracts the effect of increased $\mathrm{CO}$ and NHMC emissions (Naik et al., 2007). The decrease in year $1850 \mathrm{CH}_{4}$ lifetime is too small to result in a non-negligible RF. Although, direct $\mathrm{CH}_{4}$ emissions from year 1850 fires has a $\mathrm{RF}=0.06 \mathrm{~W} \mathrm{~m}^{-2}$.

The contributions of fires to the global annual mean tropospheric $\mathrm{O}_{3}$ column burden for year 1850, 2000 and 2100 emissions are given in Table 3. Naik et al. (2007) estimate a present day global $\mathrm{O}_{3}$ burden of 30.1 Dobson Units (DU). This is higher than our estimate of $27 \mathrm{DU}$, although, we use different emissions as well as finer horizontal resolution. Lamarque et al. (2012) estimate the average annual global burden for 1991 to 2000 as $296 \mathrm{Tg} \mathrm{O}_{3}$ defining the chemical tropopause at $100 \mathrm{ppbvO}_{3}$. Our figure for the present day, using their tropopause definition, is $273 \mathrm{Tg} \mathrm{O}_{3}$, which is within the range of interannual variability cited by Lamarque et al. (2012).

The pre-industrial total $\mathrm{O}_{3}$ burden estimated by CAM4 is less than $60 \%$ of the present-day amount, but was enhanced by $7 \%$ due to fire emissions. The increase in global burden corresponds to a $\mathrm{RF}$ of $0.05 \mathrm{~W} \mathrm{~m}^{-2}$ from the shortlived $\mathrm{O}_{3}$ response. In the present-day and future, $\mathrm{O}_{3}$ from fires is not a substantial short-term forcing on the radiation balance (Table 3). The short-lived response combined with the forcing from the primary mode response increase in $\mathrm{O}_{3}$ results in global, annual average $\mathrm{O}_{3} \mathrm{RF}$ s between 0.03 and $0.07 \mathrm{~W} \mathrm{~m}^{-2}$. Naik et al. (2007) estimate a present-day $\mathrm{O}_{3} \mathrm{RF}$ from fires of $0.11 \mathrm{~W} \mathrm{~m}^{-2}$. They also find an increase of $10 \%$ in tropospheric $\mathrm{O}_{3}$ due to fires, in contrast to the $0-2 \%$ global average increase in ozone for year 2000 simulated here. In an earlier study, Granier et al. (2000) estimated a $5 \%$ increase in global tropospheric $\mathrm{O}_{3}$ burden. The dissimilarities suggest that $\mathrm{O}_{3}$ production is sensitive to differences in fire emission inventories and also background tropospheric chemical composition. Evidence of such sensitivity was shown in global chemical transport model simulations from Fuglestvedt et al. (1999) who found that systematic decreases in $\mathrm{NO}_{\mathrm{x}}$ emissions could decrease or increase $\mathrm{O}_{3}$ in different regions depending on the background $\mathrm{NO}_{\mathrm{x}}$ concentrations.

Results of the box model integrations and estimates of the $\mathrm{RF}$ of $\mathrm{N}_{2} \mathrm{O}$ from fires are given in Table 4. The difference between the final state $\mathrm{N}_{2} \mathrm{O}$ concentrations are small, and result in small, positive RFs $\left(0.03\right.$ to $\left.0.04 \mathrm{~W} \mathrm{~m}^{-2}\right)$ for preindustrial, present day and future time periods.

\subsection{Aerosol direct effect}

Fires are the largest source of carbonaceous aerosols in the CAM5 simulations for all time periods, accounting for 80 to $95 \%$ of $\mathrm{OC}$ and $\mathrm{BC}$ emissions (Table 5). The increase in 
Table 4. Values used for the $\mathrm{N}_{2} \mathrm{O}$ box model equilibrium runs and the results of these runs. The "fire emissions removed" column uses the simulation names from Table 1 to indicate the year, fire emissions and atmospheric forcing used in the box model.

\begin{tabular}{lllllll}
\hline $\begin{array}{l}\text { Fire emissions } \\
\text { removed }\end{array}$ & $\begin{array}{l}\text { Initial } \\
{\left[\mathrm{N}_{2} \mathrm{O}\right]^{\mathrm{a}}} \\
\mathrm{ppbv}\end{array}$ & $\begin{array}{l}\text { Emissions } \\
\text { from fire }^{\mathrm{b}} \\
\mathrm{Tg} \mathrm{N} \mathrm{yr}^{-1}\end{array}$ & $\begin{array}{l}\text { Total } \\
\text { emissions }^{\mathrm{c}} \\
\mathrm{Tg} \mathrm{N} \mathrm{yr}^{-1}\end{array}$ & $\begin{array}{l}\text { Equilibrium } \\
{\left[\mathrm{N}_{2} \mathrm{O}\right]^{\mathrm{d}}} \\
\mathrm{ppbv}\end{array}$ & $\begin{array}{l}{\left[\mathrm{N}_{2} \mathrm{O}\right] \text { from }} \\
\text { fire emissions } \\
\mathrm{ppbv}\end{array}$ & $\begin{array}{l}\text { Radiative } \\
\text { Effect } \\
\mathrm{W} \mathrm{m}^{-2}\end{array}$ \\
\hline- & 275 & - & 11.7 & 279 & - & - \\
C_1850_CF & 275 & 0.45 & 11.2 & 269 & 10 & 0.03 \\
- & 316 & - & 15.7 & 369 & - & - \\
C_2000_CF & 316 & 0.40 & 15.3 & 360 & 9 & 0.03 \\
C_2000_GF & 316 & 0.58 & 15.1 & 356 & 13 & 0.04 \\
- & 372 & - & 17.1 & 401 & - & - \\
C_2100_CCF & 372 & 0.50 & 16.6 & 390 & 11 & 0.03 \\
C_2100_ECF & 372 & 0.72 & 16.4 & 385 & 16 & 0.04 \\
\hline
\end{tabular}

${ }^{a}$ Initial $\left[\mathrm{N}_{2} \mathrm{O}\right]$ values are taken from the RCP4.5 emission time series of Meinshausen et al. (2011a).

${ }^{\mathrm{b}}$ Fire emissions are global averages computed from the CLM3 simulations.

${ }^{c}$ Total emissions (minus fire emissions where applicable) are the sum of anthropogenic emissions of $\mathrm{N}_{2} \mathrm{O}$ from Meinshausen et al. (2011a) and natural emissions computed using Eq. (A28) from Meinshausen et al. (2011a), with allowances for the transport time of emitted $\mathrm{N}_{2} \mathrm{O}$ to the stratosphere and lifetime feedback, given by Meinshausen et al. (2011b).

${ }^{d}$ Lifetime is recalculated every model year for the new $\mathrm{N}_{2} \mathrm{O}$ concentration when running to equilibrium.

Table 5. Global annual average forcing terms for aerosols in all CAM5 simulations. All figures are given in $\mathrm{W} \mathrm{m}{ }^{-2}$, except for the global, annual total $\mathrm{BC}$ and $\mathrm{OC}$ emissions. The indirect effects are equivalent to the change in LWCF added to the change in SWCF.

\begin{tabular}{lccccccc}
\hline & \multicolumn{2}{c}{ BC+OC } & TOA SW & \multicolumn{2}{c}{} & \multicolumn{2}{c}{ Indirect } \\
Simulation & Emission $^{\mathrm{a}}$ Tg yr $\left.^{-1}\right]$ & $\begin{array}{c}\text { Aerosol } \\
\text { Forcing }^{\mathrm{b}}\end{array}$ & \multicolumn{2}{c}{$\begin{array}{c}\text { Direct Effect } \\
\text { Clear-sky }\end{array}$} & \multicolumn{2}{c}{ Cloud forcing } & Effect \\
\hline A_1850_NF & 5.7 & -1.42 & - & - & 24.0 & -49.7 & - \\
A_1850_CF & 84 & -1.32 & -0.15 & 0.10 & 23.7 & -51.0 & -1.60 \\
A_2000_NF & 18 & -1.51 & - & - & 24.4 & -52.5 & - \\
A_2000_CF & 90 & -1.41 & -0.15 & 0.10 & 24.1 & -53.2 & -1.00 \\
A_2000_GF & 150 & -1.38 & -0.27 & 0.13 & 24.0 & -53.7 & -1.64 \\
A_2100_NF & 5.8 & -1.46 & - & - & 24.1 & -50.6 & - \\
A_2100_CCF & 98 & -1.34 & -0.24 & 0.12 & 23.8 & -51.6 & -1.42 \\
A_2100_ECF & 140 & -1.21 & -0.25 & 0.25 & 23.5 & -51.7 & -1.74 \\
\hline
\end{tabular}

a BC: black carbon, OC: organic carbon.

b TOA SW: top-of-atmosphere shortwave; this is the total aerosol direct effect.

${ }^{c}$ LW: longwave, SW: shortwave.

annual average AOD due to fires is greatest for central Africa and the Amazonian basin, coincident with the areas of maximum fire activity (Fig. 6). Evidence of easterly transport of aerosols in the tropics can be seen in this figure. This has implications for the direct effect over often-cloudy marine environments. The modeled AOD increase (Fig. 6c with GFEDv2 emissions) matches well qualitatively and in maximum magnitude $(\sim 0.5)$ with the regional AOD change from removal of biomass burning season carbonaceous aerosols modeled by Sakaeda et al. (2011) for central Africa. Increases in AOD are projected for the future time period particularly over South America, and equatorial Africa (Fig. 6d and e). Fire emissions were responsible for decreases of up to 0.1 in AOD over N. Africa (Fig. 6). This was a result of reduced dust concentrations caused by a dynamical response to the fire aerosols which we did not explore in detail.
The substantial impact on regional AOD suggests an important role for fire aerosols on the direct effect. When only clear-sky is considered, the direct effect of fire aerosols is a negative forcing (Table 5). The values for year 2100 emissions $\left(-0.24 \mathrm{~W} \mathrm{~m}^{-2}\right.$ and $\left.-0.25 \mathrm{~W} \mathrm{~m}^{-2}\right)$ are nearly double the year 1850 and year 2000 values (both $-0.15 \mathrm{~W} \mathrm{~m}^{-2}$ ), likely a result of increased fire emissions over South America. If we include the direct effect of aerosols over clouds, the global annual average values become positive. This means that fire aerosols overlaying clouds have a substantial warming influence in our simulations. The magnitude of this effect on a global, annual average is between +0.25 and $+0.5 \mathrm{~W} \mathrm{~m}^{-2}$ in our simulations. A qualitatively similar result was shown by Wilcox (2010) and Sakaeda et al. (2011) for central Africa fire aerosols. 


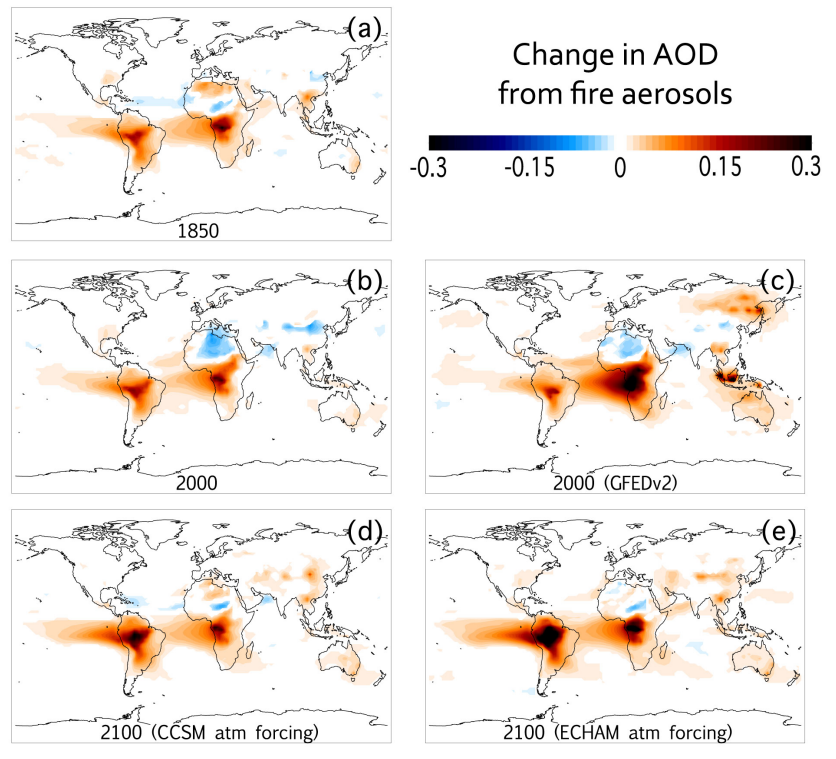

Fig. 6. The annual average change in AOD from fire aerosols for (a) 1850 CLM3 fires, (b) 2000 CLM3 fires, (c) 2000 GFEDv2 fires, (d) 2100 CLM3 fires with CCSM atmospheric forcing, and (e) 2100 CLM3 fires with ECHAM atmospheric forcing.

The present-day values for the direct effect of fire aerosols from our study of +0.10 and $+0.13 \mathrm{~W} \mathrm{~m}^{-2}$ fall within the confidence intervals of the IPCC Fourth Assessment estimate of $+0.03 \pm 0.12 \mathrm{~W} \mathrm{~m}^{-2}$ (Forster et al., 2007). Naik et al. (2007) reported a value of $+0.13 \mathrm{~W} \mathrm{~m}^{-2}$ from their modeling study, as did Reddy et al. (2005). However, the appearance of strong agreement among model studies here should be met with skepticism because the direct effect depends largely on the model representation of cloudiness, which is generally inconsistent from model to model (Naik et al, 2007; Sakaeda et al., 2011).

\subsection{Aerosol indirect effects on clouds}

Chuang et al. (2002) estimate a global cloud albedo effect of $-1.16 \mathrm{~W} \mathrm{~m}^{-2}$ for carbonaceous aerosols from fires. The results from our simulations that include aerosol effects on cloud height and lifetime, show comparable forcings between -1.74 to $-1.00 \mathrm{~W} \mathrm{~m}^{-2}$ (Table 5). The forcing is dominated by decreases in the TCF in regions off the west coast of northern South America and central Africa (Fig. 7). This suggests a globally important role for short-range transport of smoke from tropical fires on the easterly trade winds to nearcoast marine stratocumulus cloud decks. Chuang et al. (2002) note that these clouds are particularly susceptible to changes in optical thickness from an influx of high aerosol number concentration because of the low marine aerosol number concentrations. In our simulations, fire aerosols cause a two-fold increase in cloud droplet number concentration (CDNC) in the low clouds in areas off the west coasts of South America

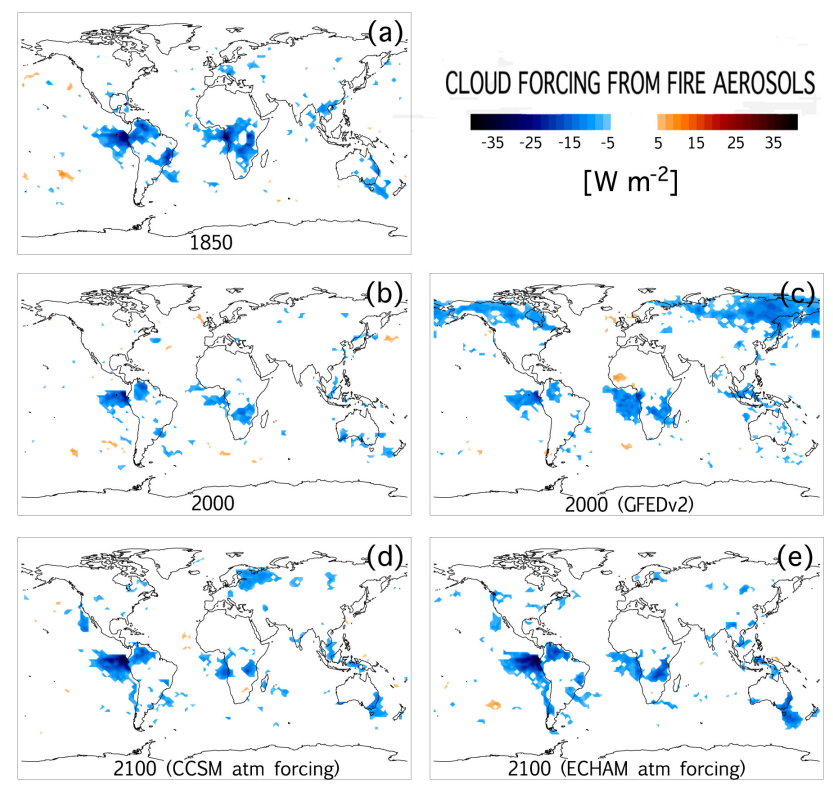

Fig. 7. The annual average change in total cloud forcing from fire aerosols for (a) 1850 CLM3 fires, (b) 2000 CLM3 fires, (c) 2000 GFEDv2 fires, (d) 2100 CLM3 fires with CCSM atmospheric forcing, and (e) 2100 CLM3 fires with ECHAM atmospheric forcing. Note that values between $-5 \mathrm{~W} \mathrm{~m}^{-2}$ and $5 \mathrm{~W} \mathrm{~m}^{-2}$ are not plotted.

and central Africa, as well as a $10 \%$ decrease in cloud droplet effective radius in the same areas. Smaller droplet sizes enhance the cloud albedo and lead to a more negative SWCF. This effect is exacerbated by the persistent, high cloud fraction maintained by marine stratocumulus decks, particularly in the Northern Hemisphere summer (Hanson, 1991), which coincides with the season of greatest fire emissions in South America and central and southern Africa. A similar effect could explain the large negative cloud forcing in Northern Hemisphere high latitude regions caused by the GFEDv2 fire emissions (Fig. 7c).

The RF due to the indirect effects of fire aerosols is $0.6 \mathrm{~W} \mathrm{~m}^{-2}$ less in magnitude in 2000 when compared to 1850. This results from anthropogenic aerosols "masking" the impact of fire emissions. The masking can be seen as a general decrease in TCF from fire aerosols in 1850 and in 2000 (Fig. 7a and 7b). Present-day fire aerosol emissions, which are very similar in amount and distribution to the preindustrial (Fig. 3), are emitted into a more polluted background, leading to a proportionally smaller impact on cloud droplet sizes. Schmidt et al. (2012) found a similar magnitude masking of the cloud albedo effect $\left(0.5 \mathrm{~W} \mathrm{~m}^{-2}\right)$ for preindustrial and present day volcanic aerosol emissions.

In a similar sense, fire emissions dampen the impact of increased anthropogenic aerosol emissions on the overall indirect aerosol effect. This is illustrated in Fig. 8 where the arrows show the difference in aerosol mass emitted ( $\mathrm{x}$ direction) and the difference in total aerosol indirect effects 


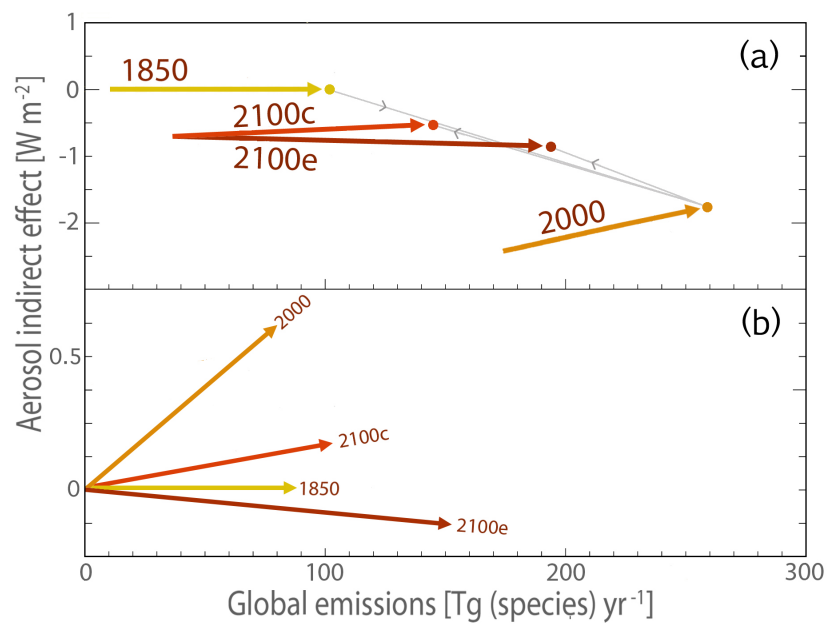

Fig. 8. Global annual average emissions of black carbon, organic carbon, and $\mathrm{SO}_{2}$ (assumed to convert to $\mathrm{SO}_{4}$ ) plotted against the aerosol indirect effects computed from CAM5 for all time periods and both future atmospheric forcings (2100c for the Community Climate System Model atmospheric forcing, and 2100e for the ECHAM5 atmospheric forcing), represented as coloured circles in (a). The coloured arrows trace the change due to fire aerosols. In (a), the change in indirect effects is referenced against pre-industrial values of $0 \mathrm{~W} \mathrm{~m}^{-2}$ with and without fires. The grey lines show the path from time period to time period. The arrows in (b) are given relative to each other, highlighting the change in angle between the fire impacts in the different time periods.

(y direction) due to fire emissions, referenced to 1850 (instead of a "no-fire" world). For example, the year "2000" arrow starts at a $\mathrm{y}$-value equal to $\mathrm{TCF}_{\mathrm{A} \_} 2000 \_\mathrm{CF}$ minus $\mathrm{TCF}_{\mathrm{A} \_1850 \_\mathrm{CF}}$, and ends at a y-value of $\mathrm{TCF}_{\mathrm{A} \_2000 \_\mathrm{NF}} \mathrm{mi}-$ nus $\mathrm{TCF}_{\mathrm{A} \_1850 \_\mathrm{NF}}$ (where the subscripts indicate the simulation used to compute the TCF). The slope of the arrows (Fig. 8b) shows the degree that fire aerosols mask the impact of anthropogenic emissions from 1850 to 2000 and to 2100. The masking is greatest for the year 2000 where the model estimate for indirect effects compared to 1850 would be $-2.36 \mathrm{~W} \mathrm{~m}^{-2}$ without any fire emissions.

Including fire emissions, the aerosol indirect effect from anthropogenic activity, defined as the difference between $\mathrm{TCF}_{\mathrm{A} \_2000 \_\mathrm{CF}}$ and $\mathrm{TCF}_{\mathrm{A} \_1850 \_\mathrm{CF}}\left(-1.76 \mathrm{~W} \mathrm{~m}^{-2}\right)$, is more negative compared to the estimates compiled by Forster et al. (2007). The disparity could result from our inclusion of additional indirect effects besides the cloud albedo effect, but recent estimates of aerosol effects show that CAM5 falls on the more negative side of the model spectrum (Quaas et al., 2009; Wang et al., 2011). Therefore, we should note that our estimates for the indirect effects from fire aerosols might be more negative compared to future studies of a similar kind using other models.

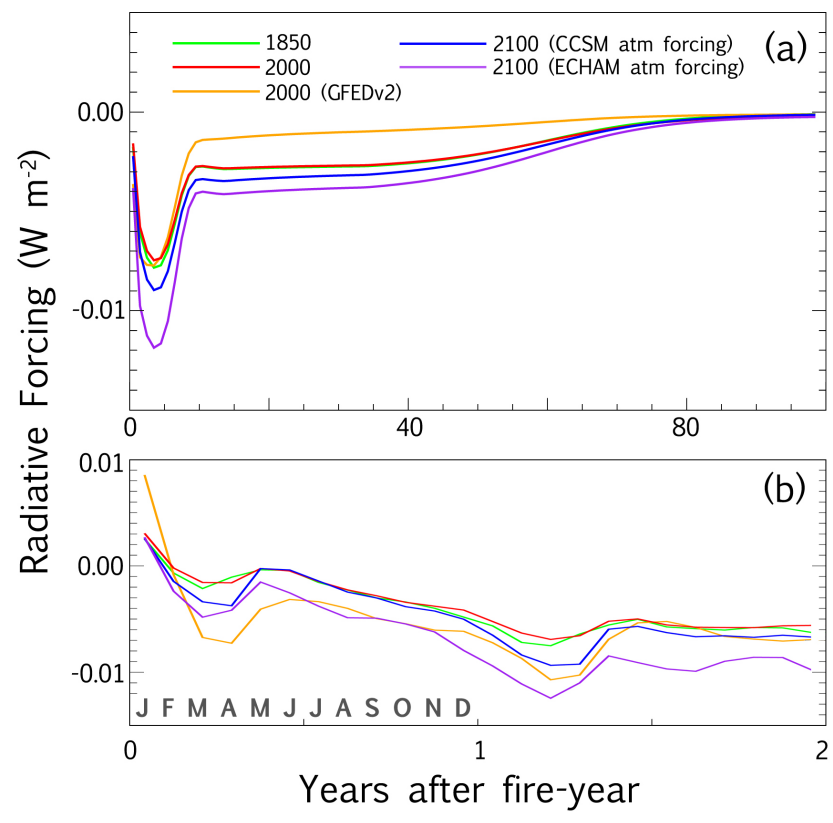

Fig. 9. A plot of the radiative forcing (RF) due to land surface albedo changes caused by fires and how it changes during the years following the fire disturbance in (a) annual averages beginning the year after a full year of fire activity, and (b) monthly averages following one full year of fire activity. Each colour represents different fire emissions from CLM3 or from GFEDv2 as indicated by the legend.

\subsection{Albedo changes}

The RF of land surface albedo changes due to fires is shown in Fig. 9. To estimate the total impact of yearly fires, which can persist for years, we sum the yearly global RF from land surface albedo change. This assumes the fire return time exceeds the albedo recovery time. The total RFs from surface albedo changes from fires were $-0.20 \mathrm{~W} \mathrm{~m}^{-2}$, $-0.20 \mathrm{~W} \mathrm{~m}^{-2}$, and $-0.26 \mathrm{~W} \mathrm{~m}^{-2}$ for 1850,2000 , and 2100 respectively, with the year 2100 figure being the average between the two future simulations. The impact of the GFEDv2 fires ( $\mathrm{RF}$ of $-0.11 \mathrm{~W} \mathrm{~m}^{-2}$ ) is reduced due to a smaller proportion of mid-latitude forest fires and more grassland fires (Fig. 3c).

Figure 10 shows the net radiative forcing of surface albedo changes from fires integrated over different time periods. The global average forcing becomes negative after one year as grassland albedo has returned to a pre-fire state and tropical forests are replaced by more reflective secondary vegetation. A similar replacement effect occurs in extratropical forests on longer timescales. Ten and fifty years after an extratropical forest fire, the higher albedos of secondary vegetation and, in some regions, snow, are exposed. The impact of increased snow exposure in burned areas during the Northern Hemisphere winter is evident in the monthly timeseries (Fig. 9b) and also in the biome-specific RFs (Fig. 10). In 


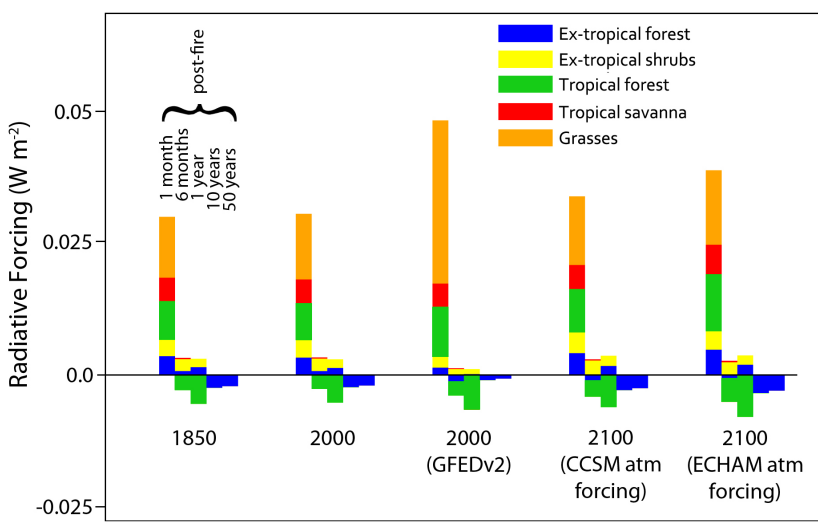

Fig. 10. Global RF due to land surface albedo change from fires plotted for major biomes and for different lengths of time after the fire occurred. Each set of bars represents different fire emissions from CLM3 or from GFEDv2 as indicated by the labels.

the months of March and April the RF decreases as Northern Hemisphere solar insolation increases and some exposed ground is still snow-covered. Globally, increases in forest albedo lead to a negative RF from albedo changes from one year to one hundred years post-fire.

SNICAR results show a non-zero but very small RF (less than $0.01 \mathrm{~W} \mathrm{~m}^{-2}$ ) from fire aerosol deposition on snow and ice surfaces, for all time periods. This is consistent with Bowman et al. (2009) who estimate that the glbal RF from fireemitted $\mathrm{BC}$ depositing onto snow is negligible.

\subsection{Aerosol indirect effects on biogeochemistry}

Fire aerosols not only impact climate directly, but can cause an indirect effect on climate through biogeochemical cycles, especially the $\mathrm{C}$ cycle (Mahowald, 2011). There are two ways that fire aerosols can impact biogeochemistry, first through adding nutrients (or pollutants) and secondly through modifying climate. Fire gases and aerosols contain $\mathrm{N}$ and phosphorus $(\mathrm{P})$, which can fertilize downwind nutrient limited forests (e.g. Vitousek, 1984; Mahowald et al., 2005; Chen et al., 2010). It has been speculated that the increased $\mathrm{P}$ in ash in the Amazon due to increased biomass burning has contributed to the larger uptake of $\mathrm{C}$ observed during the 1980s and 1990s, resulting in a RF of between 0 and $-0.12 \mathrm{~W} \mathrm{~m}^{-2}$ (Mahowald, 2011).

$\mathrm{N}$ deposition from anthropogenic sources is thought to be increasing the drawdown of $\mathrm{CO}_{2}$ from terrestrial ecosystems causing a forcing of between -0.24 and $-0.74 \mathrm{~W} \mathrm{~m}^{-2}$ (Mahowald et al., 2011b): only half of that is in the aerosol form, but for this problem both gas and aerosol impacts on biogeochemistry are important. The ratios of $\mathrm{N}$ emissions from fire (from CLM3) to present day anthropogenic emissions (Lamarque et al., 2010) are $11 \%, 9 \%$ and $15 \%$ in 1850 , 2000 and 2100 (averaged between the two ensemble future simulations). If this impact were linear on the $\mathrm{N}$ deposition, this would imply between -0.02 and $-0.08 \mathrm{~W} \mathrm{~m}^{-2}$ from the fertilization of land due to fires in the pre-industrial, with very similar values (within the uncertainties) for present and future values.

Fire aerosols are also thought to contain soluble iron $(\mathrm{Fe})$ (Guieu et al., 2005), an important micronutrient for ocean biogeochemistry (Martin et al., 1991). Estimates of the increased uptake of $\mathrm{CO}_{2}$ in the oceans, from both increases in the solubilization of $\mathrm{Fe}$ (due to fossil fuel sulfur dioxide emissions, industrial combustion soluble $\mathrm{Fe}$ and biomass burning soluble $\mathrm{Fe}$ ), suggest a reduction in the $\mathrm{CO}_{2}$ of $2 \mathrm{ppm}$ (Krishnamurthy et al., 2009). If we assume up to half of this is from fires (likely an overestimate), this results in a radiative forcing of $0.02 \mathrm{~W} \mathrm{~m}^{-2}$.

Finally the climate impacts of fires can themselves impact the carbon cycle (e.g. Jones et al., 2001; Mahowald, 2011; Mahowald et al., 2011a, b). Aerosols modify temperature, leading to a response in $\mathrm{C}$ uptake by the land and ocean (Mahowald, 2011). They also increase the ratio of diffuse to direct radiation reaching the surface, enhancing $\mathrm{C}$ uptake by vegetation (Mercado et al., 2009), and affect vegetation by redistribution of precipitation. These impacts are not well understood (Friedlingstein et al., 2006; Friedlingstein and Prentice, 2010; Mahowald et al., 2011a), however estimates from coupled-carbon-climate models suggest a roughly linear response with climate forcing of between 0 and $40 \mathrm{ppm}$ of $\mathrm{CO}_{2}$ for a $1.4 \mathrm{~W} \mathrm{~m}^{-2} \mathrm{RF}$ (Mahowald et al., 2011a). This global forcing of fires (referred to here as the climate-BGC feedback) is estimated by applying the linear response relationship between $\mathrm{CO}_{2}$ and climate forcing to the sum of all fire RFs. This forcing is separate from the direct impact of fires on atmospheric $\mathrm{CO}_{2}$ concentrations. We estimate values of the fire climate-BGC feedback RF of $-0.22 \mathrm{~W} \mathrm{~m}^{-2}$, $-0.10 \mathrm{~W} \mathrm{~m}^{-2}$ and $-0.10 \mathrm{~W} \mathrm{~m}^{-2}$ for 1850,2000 , and 2100 , respectively.

\section{Summary of radiative forcings}

Figure 11 shows the RF due to fires for all impacts assessed in this study for pre-industrial conditions. The $\mathrm{CO}_{2}$ and aerosol indirect effect RFs are dominant and partially canceling. The sum of these and the other minor RFs is a negative radiative imbalance, augmented by the climate-BGC feedback, for a total $\mathrm{RF}$ of $-1.02 \mathrm{~W} \mathrm{~m}^{-2}$.

The change in all RFs between 1850 to 2000 and 1850 to 2100 are illustrated in Fig. 12 with the range in RF between the two future atmospheric forcing datasets shown. The largest change in fire RF from 1850 to 2000 is caused by the aerosol indirect effect, which increased by $0.6 \mathrm{~W} \mathrm{~m}^{-2}$ (Fig. 12). While emissions from fires during the two time periods are similar in magnitude (Fig. 2) and in geographical distribution (Fig. 3), the impacts of present-day fire aerosols onto clouds are partially masked by higher background aerosol number concentrations. The overall RF of 
Table 6. Radiative forcings for all fire impacts considered in this study. All values except efficacies are given in $\mathrm{W} \mathrm{m}{ }^{-2}$. The direct effect for clear sky is not included in the total.

\begin{tabular}{lcccccc}
\hline & 1850 & \multicolumn{2}{c}{2000} & \multicolumn{2}{c}{2100} \\
\hline Radiative Effect & CLM3 & CLM3 & GFEDv2 & CLM3_C & CLM3_E & EFFICACY ${ }^{\mathrm{b}}$ \\
Carbon Dioxide & 0.83 & 0.62 & - & 0.75 & 0.91 & 1 \\
Methane & 0.06 & 0.05 & 0.13 & 0.08 & 0.13 & 1.45 \\
Nitrous Oxide & 0.03 & 0.03 & 0.04 & 0.03 & 0.04 & 1.04 \\
Tropospheric Ozone & 0.07 & 0.03 & 0.03 & 0.04 & 0.06 & 0.82 \\
Direct Effect - All sky & 0.10 & 0.10 & 0.13 & 0.12 & 0.25 & $0.58,0.91^{\mathrm{c}}$ \\
Direct Effect - Clear sky & -0.15 & -0.15 & -0.27 & -0.24 & -0.25 & - \\
Indirect Cloud Effects & -1.60 & -1.00 & -1.64 & -1.42 & -1.74 & - \\
Indirect BGC Effects & $-0.09 \pm 0.09$ & $-0.08 \pm 0.08$ & $-0.15 \pm 0.12$ & $-0.10 \pm 0.09$ & $-0.13 \pm 0.10$ & - \\
Land Albedo Changes & -0.20 & -0.20 & -0.11 & -0.23 & -0.29 & - \\
Snow/Ice Albedo Changes & 0.00 & 0.00 & 0.01 & 0.00 & 0.00 & 1.7 \\
Feedback onto C-cycle & $-0.22 \pm 0.22$ & $-0.10 \pm 0.10$ & - & $-0.10 \pm 0.10$ & $-0.10 \pm 0.10$ & - \\
TOTAL & -1.02 & -0.55 & - & -0.83 & -0.87 & -
\end{tabular}

a Acronyms indicate the set of fire emissions used to compute the forcings. CLM3 indicates that the fires were predicted by the Community Land Model version 3.5 with atmospheric forcing from the Community Climate System Model (CCSM), denoted as "_C", or from ECHAM5/MPI-OM, denoted as "_E". Other present day fire information was taken from the Global Fire Emissions Database (GFEDv2).

b Efficacy values were taken from Hansen et al. (2005).

c Efficacy for direct effects of black carbon and organic carbon aerosols from fires, respectively.

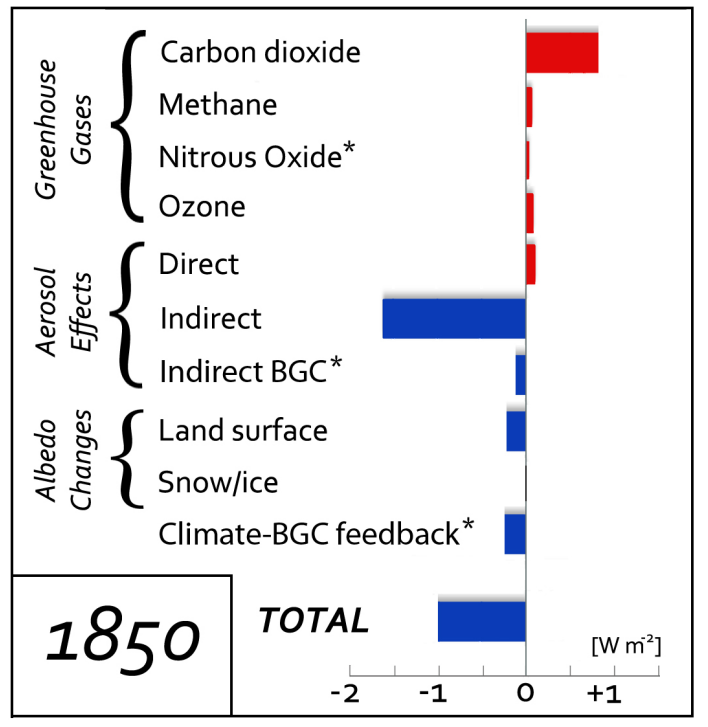

Fig. 11. Global, annual average RF for the various impacts of fires examined in this study, plotted for pre-industrial fires relative to the no-fire scenario. Asterisks indicate RFs that were computed using emissions data and not the CAM model integrations, or the CLM3 no-fire simulations.

fires estimated by the model simulations increases by about $0.5 \mathrm{~W} \mathrm{~m}^{-2}$ from 1850 to 2000 . In other words, anthropogenic activities have caused the cooling potential of global modeled fires to decrease by $47 \%$ since 1850 even with very little trend in modeled fire emissions during this time.

There are substantial differences between the year 2000 $\mathrm{RFs}$ for $\mathrm{CH}_{4}$, and the aerosol indirect effect, computed using the model predicted fire emissions and the GFEDv2 emissions (Table 5). The higher magnitude forcings associated with the GFEDv2 emissions reflect the underestimation of global fire emissions by the Kloster et al. (2010) model within CLM3. In particular, the under-prediction of boreal fire activity (due in part to missing peatland fire emissions) and tropical grassland fires contribute to the reduced magnitude aerosol indirect effect. Although a $\mathrm{CO}_{2}$ forcing was not computed from the GFEDv2 emissions, the increased $\mathrm{C}$ lost from fires (compared to the CLM3 fires) would have resulted in a higher magnitude $\mathrm{CO}_{2} \mathrm{RF}$ as well.

From years 2000 to 2100 , the projected fire emissions depend on the projected climate change applied as atmospheric forcing (e.g. Kloster et al., 2012). These projections give some sense of the range in predicted fire activity in the future. We use the differences between the results of the two projections as bounds on our RF estimates for the future (Fig. 12). The high fire emissions projection (ECHAM forcing) leads to a $\mathrm{CO}_{2} \mathrm{RF}$ that is comparable to the pre-industrial value. Greater amounts of carbon are lost to the atmosphere by burning in this scenario, but the impact is buffered by the $\mathrm{CO}_{2}$ saturation effect.

The aerosol effects depend strongly on the different fire emissions. The direct effect is increased by $0.13 \mathrm{~W} \mathrm{~m}^{-2}$ when the ECHAM atmospheric forcing is used, compared to the CCSM atmospheric forcing. This is balanced somewhat by a decrease in aerosol indirect effects of $0.32 \mathrm{~W} \mathrm{~m}^{-2}$ from the ECHAM to the CCSM, a result of the greater fire emissions in the ECHAM scenario. The impact of the background aerosol on the fire aerosol RF is likely to be different in year 2100 than it was in 2000. Non-fire aerosol emissions of BC, $\mathrm{OC}$, and sulfate decrease globally by almost $80 \%$ from year 


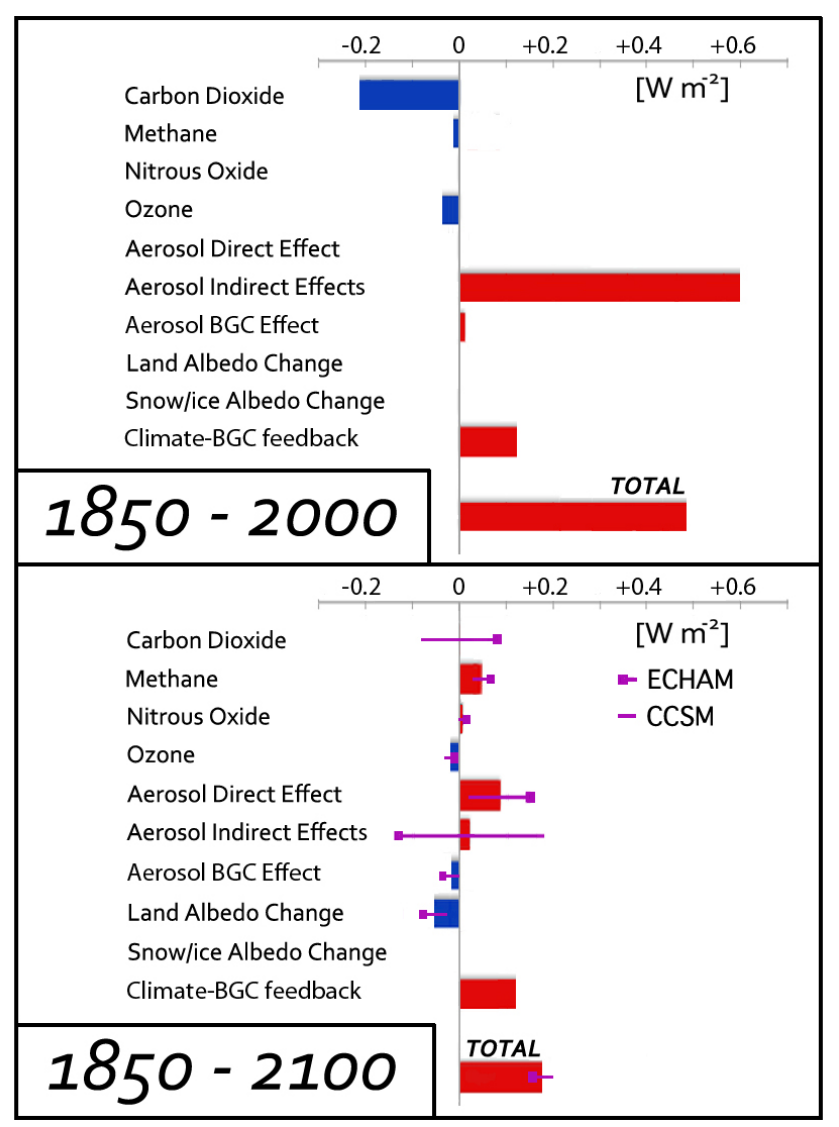

Fig. 12. Global, annual average RF for the various impacts of fire examined in this study relative to the pre-industrial forcings (Fig. 11) for present day fires (1850-2000) and for year 2100 fires (1850-2100). For 1850-2100, the average RF for the two sets of fire emissions used in 2100 (CCSM and ECHAM atmospheric forcing) is given with the range shown as the purple lines.

2000 to year 2100 in the RCP4.5 scenario (see Fig. 8). The degree of masking of the fire aerosol indirect effects by anthropogenic aerosols in year 2100 is, therefore, likely very small compared to the masking in year 2000. Altogether, the two very different future fire emissions scenarios lead to similar total fire RFs. The magnitude of the model-predicted year 2100 fire RF has decreased from the present-day, being about $0.2 \mathrm{~W} \mathrm{~m}^{-2}$ greater than the year 1850 value (Fig. 12).

Past modeling studies found that different forcing agents may have different climate sensitivities, known as efficacies when defined in relation to the climate sensitivity of $\mathrm{CO}_{2}$ forcing (Hansen et al., 2005; Solomon et al., 2007). For example, while the RF of fire aerosol deposition onto snow and ice surfaces is near zero, the efficacy of this forcing could be up to three times greater than $\mathrm{CO}_{2}$ as the aerosols accelerate melting of the snow (Flanner et al., 2007). The values from Hansen et al. (2005) are given in Table 6.

The total fire RF in all time periods is dominated by the $\mathrm{CO}_{2}$ forcing and the aerosol indirect effects. Therefore, it is notable that the indirect aerosol effect on clouds is highly uncertain in model predictions (Solomon et al., 2007). The IPCC AR4 use a range of confidence of $1.5 \mathrm{~W} \mathrm{~m}^{-2}$ to bound their estimates for the first anthropogenic aerosol indirect effect (Forster et al., 2007). Improvements in our understanding of aerosol effects on clouds could influence our results because of their prominent role in the total fire RF.

Several assumptions are introduced for estimating the other major fire $\mathrm{RF}, \mathrm{CO}_{2}$. Fires shape ecosystems by altering population dynamics and species composition (Bond et al., 2005; Harrison et al., 2010; Rogers et al., 2011), affecting ecosystem productivity and decomposition rates. However, the PFT distribution in CLM3 does not react to fires. If a dynamic vegetation response to fires were included, we expect the $\mathrm{CO}_{2} \mathrm{RF}$ would increase as forests would expand in the absence of fire and store greater amounts of $\mathrm{C}$. We also assume that the atmospheric $\mathrm{CO}_{2}$ forcing remains constant in CLM3 with or without fires. If $\mathrm{CO}_{2}$ were interactive within CLM3, removing fires would decrease atmospheric $\mathrm{CO}_{2}$, reducing vegetation growth and terrestrial $\mathrm{C}$ storage. This was shown to be important in a C-cycle model study of land cover change impacts on terrestrial C storage (Arora and Boer, 2010), although its importance is likely to be diminished in simulations that include N-limitation, as in this study. Future trends in global $\mathrm{N}$ deposition will impact terrestrial C storage but were not accounted for in this study.

The premise of this modeling study, that atmospheric RFs can be derived from fire emissions computed offline, requires assuming that fire effects on climate do not immediately feedback onto fire activity. We circumvent this issue by using short simulation times and limiting our conclusions to global average radiative forcing. However, because fires are spatially variable, the climate response to associated forcings is likely to vary considerably between regions. Regional variability applies especially to forcings from short-lived greenhouse gases and aerosols, as well as surface albedo changes, and is not expressed in global average RFs. These local irregularities in forcing could drive variations in regional climate and atmospheric circulation. Tosca et al. (2012) found that the direct effect of fire aerosols weakens the Hadley circulation, leading to changes in tropical precipitation distribution. Large, local RF from fire aerosols west of equatorial Africa could cause reductions in precipitation over central Africa, according to Sakaeda et al. (2011). Both studies suggest a feedback of fire aerosols onto fires themselves through precipitation changes. To understand the full climate response, fires would ideally be interactive with the atmosphere in future simulations.

\section{Conclusions}

Comprehensive assessment of the role of fires in climate is challenging because of the complex nature of the numerous fire/Earth system interactions (Fig. 1). While previous stud- 
ies focus on specific fire effects, or on a subsample of processes (e.g. Naik et al., 2007; Bowman et al, 2009; Pechony and Shindell, 2010; Stone et al., 2011), here we calculate the total impact of fire on the Earth's radiative budget. We use model-generated emissions inventories from time periods centered on 1850, 2000 and 2100 to examine how the $\mathrm{RF}$ of fires has changed since pre-industrial times, and how it may change in the future (Figs. 11, 12; Table 6).

The uncertainties in net radiative forcing of fires are large and difficult to quantify, including uncertainty in the total fire emissions, spatial variability of emissions, the model representation of clouds, the trajectory of land use and future atmospheric composition, and the role of nitrogen in the land model. We attempt to address some of these uncertainties by comparing the RFs calculated using the prognostic fire in the Earth system model (Kloster et al., 2010) to those calculated using the GFEDv2 inventory (Table 6). The results suggest that there are still gaps in model estimates of the distribution of fires (Fig. 3) and a need for improvement. Continued progress in the development of fire emission inventories based on satellite observations, such as the GFED (van der Werf et al., 2010), is essential for model validation. Within the model, prognostic burn severity may be the next major step toward better matching the predicted fields to the inventories. Likewise, peatland fires are needed in the model representation. Future modeling work on fire impacts would also benefit from dynamic vegetation that captures the succession of different PFTs following fire and the evolution of different fire regimes.

In our study fires have an overall negative radiative forcing, or cooling influence, for all time periods. The magnitude of the cooling decreases between 1850 and 2000, in large part because of the masking of fire aerosols impacts on clouds by anthropogenic aerosols. Between years 2000 and 2100, global emissions from fires depend primarily on the applied climate forcing (Kloster et al., 2012). However, the RF imposed by fires in 2100 is similar for both emission projections used in this study, despite the range in total emissions between them. The greater $\mathrm{RF}$ of $\mathrm{CO}_{2}$ from fires in the case with ECHAM atmospheric forcing $\left(0.91 \mathrm{~W} \mathrm{~m}^{-2}\right.$ compared to $0.75 \mathrm{~W} \mathrm{~m}^{-2}$ for CCSM atmospheric forcing) is compensated by a more negative aerosol indirect effect RF $\left(-1.74 \mathrm{~W} \mathrm{~m}^{-2}\right.$ compared to $-1.42 \mathrm{~W} \mathrm{~m}^{-2}$ for CCSM atmospheric forcing). We project that year 2100 fires will apply a stronger cooling forcing on the climate $\left(-0.85 \mathrm{~W} \mathrm{~m}^{-2}\right)$ when compared to year 2000 fires $\left(-0.55 \mathrm{~W} \mathrm{~m}^{-2}\right)$.

In general, we find that the background environment into which fires emit aerosols and trace gases can be just as important, if not more, than the magnitude of the emissions. Also, the effects of fires onto ecosystems by moderating $\mathrm{C}$ storage are a major forcing on the atmosphere. We conclude that anthropogenic impacts on fire activity, igniting and suppressing fires, are not the only paths by which humans can affect the climate forcing from fires. Instead, fires as a process are highly integrated within the Earth system and respond to nat- ural and anthropogenic changes. Comprehensive model representations of the Earth system, therefore, must include the effects of fires on the climate and preferably, the effects of climate on fires and fire impacts as well.

\section{Appendix A}

\section{Scaling of aerosol emissions in CAM5}

Recent studies suggest that GFEDv2 bottom-up estimates of carbon emissions from biomass burning in tropical regions, especially South America, may be biased low when compared to satellite, surface, and airborne observations of aerosol optical depth at a wavelength of $550 \mathrm{~nm}\left(\mathrm{AOD}_{550}\right)$ (e.g. Bian et al., 2007; Chin et al., 2009). To compensate for this apparent bias, the modeled $\mathrm{AOD}_{550}$ based on the GFED emissions is scaled to match a dataset or combination of datasets of observed AOD $_{550}$ (e.g. Nevison et al., 2008; Matichuk et al., 2008).

Scaling of biomass burning emissions in our study follows the method of Johnston et al. (2012) with only slight modifications. This method is different from previous schemes as it identifies high-fire locations, and low-fire and high-fire seasons, and scales the AOD for each separately. In this way the influence of the background aerosols on the overall scaling, a source of uncertainty in this process (Matichuk et al., 2008), is reduced. We performed two additional 5-year simulations with CAM5 and MAM3 to optimize aerosol emissions. These simulations were identical to A_2000_GF and A_2000_NF but used the un-scaled GFEDv2 emissions averaged over the period 1997-2002. We define an AOD $_{\text {CAM }}$ as the 5-yr average monthly mean $\mathrm{AOD}_{550}$ from the simulation with GFED fire emissions and AOD $_{\text {NOFIRE }}$ as the 5-yr average monthly mean $\mathrm{AOD}_{550}$ from the simulation with no

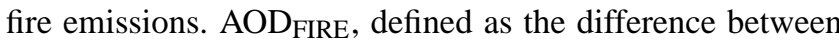
$\mathrm{AOD}_{\mathrm{CAM}}$ and $\mathrm{AOD}_{\text {NOFIRE}}$, is considered to be the model estimate of $\mathrm{AOD}_{550}$ resulting from fire emissions.

The model data were scaled using observations from the Moderate Resolution Imaging Spectroradiometer (MODIS) and Multi-angle Imaging Spectroradiometer (MISR) instruments as well as ground based observations from the Aerosol Robotic Network (AERONET). Monthly mean values of $\mathrm{AOD}_{550}$ were derived from satellite retrievals from the years 2000 to 2009, and also from the full record of each AERONET station with data for at least one yearly cycle. Since we are comparing monthly climatologies, and these may be averaged over different time periods, we expect to introduce some error related to the interannual variability of fires. However, the variability in fire emissions from year to year is low in Africa and South America (van der Werf et al., 2006) where the largest amounts of fire emissions occur.

The results of a regression analysis of the model and satellite AOD data onto the AERONET observations for all station locations are given in Table A1. Both model and 
Table A1. Regression of the monthly mean Community Atmosphere Model (CAM) and MODIS and MISR satellite aerosol parameters onto the AERONET observations for all months and all AERONET stations. Coefficients are the slope of the linear regression (Slope), the $\mathrm{y}$-intercept (Intercept), the correlation coefficient (R-squared), the root mean squared error (RMSE), the slope when forced through point $(0,0)$ (ZI-SLOPE), and the adjustment factor for the satellite aerosol optical depth (AOD-adj). Italics represent the results of computations on the subset of observations for which the satellite AOD $>0.2$.

\begin{tabular}{|c|c|c|c|c|c|c|}
\hline Aerosol & Slope & Intercept & R-squared & RMSE & ZI-SLOPE & AOD-adj \\
\hline \multicolumn{7}{|l|}{ Parameter } \\
\hline CAM AOD & 0.34 & 0.07 & 0.29 & 0.10 & & \\
\hline MODIS AOD & 0.45 & 0.18 & 0.51 & 0.10 & 0.81 & 1.23 \\
\hline MISR AOD & 0.23 & 0.20 & 0.43 & 0.06 & 0.58 & 1.72 \\
\hline CAM SSA $^{\mathrm{a}}$ & 0.57 & 0.36 & 0.33 & 0.03 & & \\
\hline MISR SSA & 0.23 & 0.76 & 0.06 & 0.03 & & \\
\hline CAM AAOD $^{b}$ & 0.17 & 0.03 & 0.03 & 0.02 & & \\
\hline MISR AAOD & 0.06 & 0.01 & 0.08 & 0.01 & & \\
\hline
\end{tabular}

a This is the single scattering albedo (SSA).

b AAOD equals the absorbing AOD, or the portion of the AOD that is not due to scattering.

satellites underestimate AOD when compared to AERONET as shown by the slope of the regression line, although the satellite retrievals show less spread about the line. Where AOD is reported less than 0.2 by MODIS the observation is removed following the recommendation of Hyer et al. (2011) who note that the low-AOD observations approach the signal to noise threshold. For satellite retrievals a separate slope is computed where the regression line is given a y-intercept of zero. Hyer et al. (2011) also found non-zero intercepts when regressing AERONET AOD data onto the MODIS dataset and writes that these are often caused by retrieval errors. The same adjustments are made to the MISR data.

Kahn et al. (2005) compare MISR retrieved AOD to AERONET observations and find much better agreement. However, they made comparisons for individual satellite passes, whereas we are inclined to use monthly climatologies. We expect the differences between our analysis and that of Kahn et al. (2005) are due to this averaging. Nevertheless, because the model AOD is more similar to the satellite AOD than either of them are to the AERONET data, we perform an adjustment to the satellite AOD data prior to the scaling of the model AOD. The satellite estimates of $\mathrm{AOD}_{550}$ are prepared by simply applying the slope adjustment factors given in Table A1. These are computed to adjust the slope of the regression line between the MODIS and MISR AOD and the AERONET AOD to one.

The regions for scaling were defined as the $1 / 3$ of the area within each of the 14 GFED-defined regions (van der Werf et al., 2006) with the highest value of AOD FIRE. All of the following computations are done on these 14 sub-regions. Fire emissions are largely seasonal (van der Werf et al., 2006) making it possible to designate a fire season, defined as the four months out of an annual cycle with the highest monthly mean value of AOD $_{\text {FIRE }}:$ AOD $_{\text {NOFIRE, }}$ and a no-fire season, defined as the four months with the lowest mean ratio, for each sub-region. The $\mathrm{AOD}_{\mathrm{CAM}}$ averaged over each region
Table A2. Values of the scaling factors $\alpha$ and $\beta$ for the seven GFED regions with annual fire emissions of greater than $100 \mathrm{Tg} \mathrm{Cyr}^{-1}$. The values of $\alpha$ for MODIS and MISR data were averaged and rounded to the nearest multiple of 0.5 to give the scaling factor applied to the fire emissions in the forward model simulations.

\begin{tabular}{llllll}
\hline & \multicolumn{2}{c}{ MODIS } & \multicolumn{2}{c}{ MISR } & Scaling \\
\hline Region $^{\mathrm{a}}$ & $\beta$ & $\alpha$ & $\beta$ & $\alpha$ & Factor \\
SHSA & 1.61 & 1.87 & 2.43 & 1.82 & 2.0 \\
NHAF & 0.89 & 0.48 & 0.79 & 1.09 & 1.0 \\
SHAF & 2.13 & 2.59 & 2.33 & 3.52 & 3.0 \\
BOAS & 1.11 & 3.88 & 4.39 & 2.13 & 3.0 \\
SEAS & 2.53 & 1.37 & 2.48 & 1.81 & 1.5 \\
EQAS & 3.63 & 2.51 & 3.67 & 3.32 & 3.0 \\
AUST & 1.15 & 1.40 & 1.43 & 3.47 & 2.5 \\
\hline
\end{tabular}

${ }^{a}$ SHSA: Southern hemisphere South America, NHAF: Northern hemisphere Africa, SHAF: Southern hemisphere Africa, BOAS: Boreal Asia, SEAS: Southeastern Asia, EQAS: Equitorial Asia, AUST: Australia.

for the no-fire season months, as well as the $\mathrm{AOD}_{550}$ estimates from MODIS and MISR for the same months and same regions, are used to compute a scaling factor for the background aerosol, $\beta$, using this expression adapted from Johnston et al. (2012):

$\mathrm{AOD}_{\text {satellite }}=\beta \times \mathrm{AOD}_{\text {NOFIRE }}+\mathrm{AOD}_{\text {FIRE }}$

The scaling factor $\beta$ was chosen to satisfy this relationship for all 14 sub-regions. Note that $\beta$ is used only for computation of $\alpha$ and is not applied to the model emissions. Using $\beta$, the fire emissions scaling factor, $\alpha$, is chosen to satisfy the following expression for the fire months (adapted from Johnston et al., 2012):

$\mathrm{AOD}_{\text {satellite }}=\beta \times \mathrm{AOD}_{\text {NOFIRE }}+\alpha \times \mathrm{AOD}_{\text {FIRE }}$

We applied the results of this analysis to regions that emit greater than $100 \mathrm{Tg} \mathrm{C}$ annually from biomass burning 

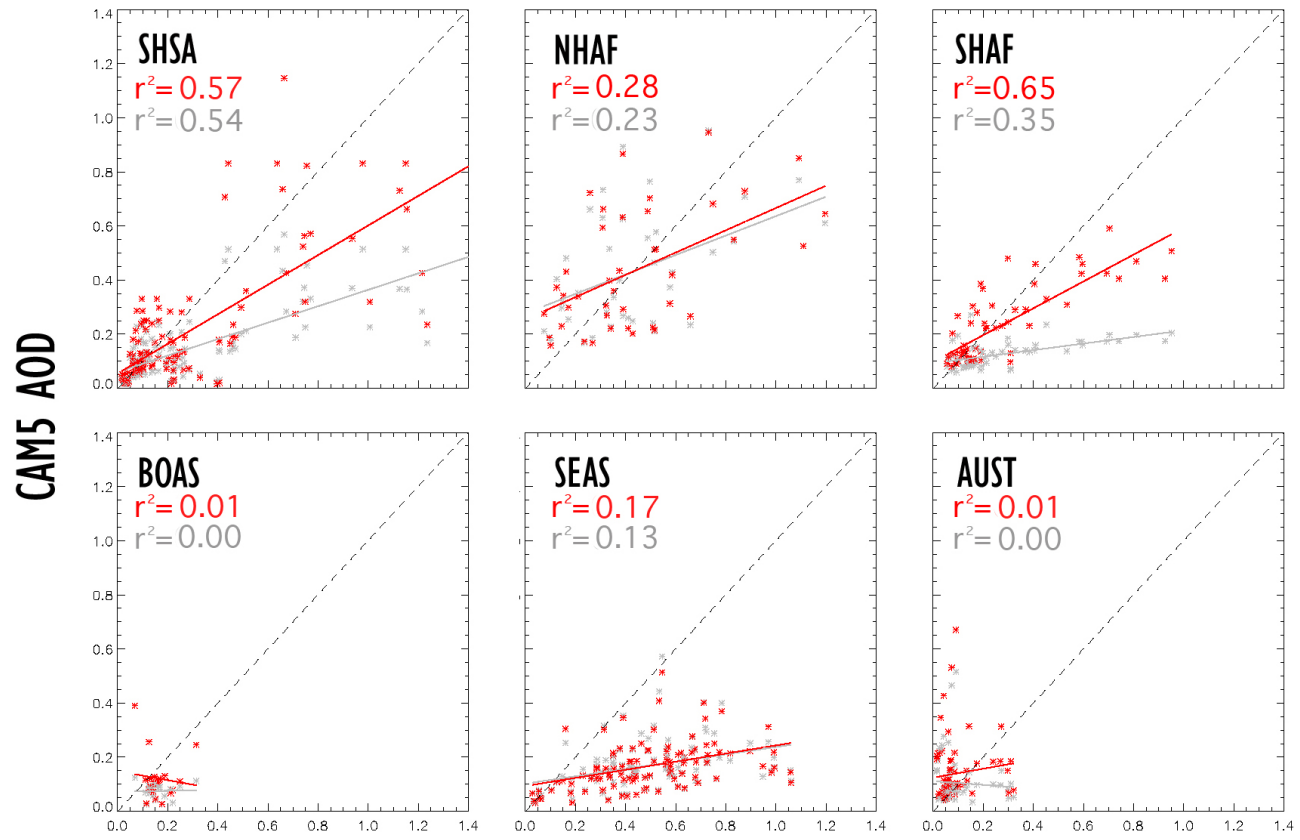

\section{AERONET AOD}

Fig. A1. Scatterplots of the monthly mean model AOD vs. AERONET AOD for different GFED regions and the globe with linear regression lines plotted. Results from simulations with both the un-scaled GFEDv2 emissions (gray) and scaled emissions (red) are shown. The region abbreviations are Southern Hemisphere South America (SHSA), Northern Hemisphere Africa (NHAF), Southern Hemisphere Africa (SHAF), boreal Asia (BOAS), southeastern Asia (SEAS), and Australia (AUST). Equatorial Asia (EQAS) is excluded due to the small number of AERONET data points within this region.

(scaling factors given in Table A2). These were Southern Hemisphere South America (SHSA), northern and Southern Hemisphere Africa (NHAF, and SHAF, respectively), boreal Asia (BOAS), southeast Asia (SEAS), equatorial Asia (EQAS), and Australia (AUST). The average of $\alpha$ computed for MODIS and MISR is used to approximate a scaling factor for fire emissions in the high-fire emission regions. Matichuk et al. (2007) found that varying the initial mass of biomass burning emissions led to linear variations in the resulting $\mathrm{AOD}_{550}$. Therefore the scaling factor is directly applied to the model emissions. The impact of applying the scaling factors to the model emissions was assessed with an additional 5-year simulation using the scaled GFEDv2 emissions. The results of this simulation are shown in Fig. A1 in comparisons of the model and AERONET AOD 550 . The regions SHAF, SHSA, and EQAS have the highest fraction of model AOD from fires and see the largest increase in model AOD (note that the results for EQAS are not plotted due to the very small number of AERONET stations in this region). The change is less visible in the other regions where either the scaling factor was set to one, or where fires do not contribute significantly to the model AOD. In all cases the model AOD is still low compared to the AERONET monthly values. Overall, the scaling more than doubled fire aerosol emissions globally (increase of $106 \%$ ) using the scaling of the GFEDv2 emissions as an example. The increase in fire aerosol emis- sions resulted in a $7 \%$ increase in global, annual averaged AOD from all aerosols (magnitude increase of 0.01) again using the GFEDv2 emissions.

\section{Appendix B}

\section{$\mathrm{B1} \mathrm{CO}_{2}$ pulse response function}

If we conceive that the terrestrial $\mathrm{C}$ storage prevented by yearly, global fires is emitted annually as a pulse of $\mathrm{CO}_{2}$ we can estimate the airborne fraction of the pulse after a given time period using a response function. Enting et al. (1994) generated $\mathrm{CO}_{2}$ pulse response functions from several models including the ocean-carbon model introduced by Siegenthaler and Joos (1992). They defined coefficients for the response function given pre-industrial $\mathrm{CO}_{2}$ parameters (IINIT), for emissions sustaining $1990 \mathrm{CO}_{2}$ concentrations (IP90), and for an emissions scenario leading to $\mathrm{a} \mathrm{CO}_{2}$ concentration of 650 ppmv by the year 2100 (IPERT). To estimate the concentration of $\mathrm{CO}_{2}$ in the atmosphere from fires for the present and future time periods, we calculate a yearly $\mathrm{CO}_{2}$ pulse that is equivalent to the annual difference in terrestrial $\mathrm{C}$ storage due to fires. Then we apply the response function to compute the airborne fraction of the yearly pulse 
at the assessment year (either 2000 or 2100). Each pulse is multiplied by the corresponding airborne fraction, and the results are summed over the given time period.

In this sense, we are assessing the change in atmospheric $\mathrm{CO}_{2}$ relative to the pre-industrial state from fires that occurred before 2000, for present day, and before 2100 for the future. The IP90 response function is applied to these pulses yearly from 1850 to 1990 and IPERT is used from 1990 to 2100. IP90 was designed assuming present day background $\mathrm{CO}_{2}$ concentrations initially, meaning it is not directly applicable to the problem of increasing $\mathrm{CO}_{2}$ concentrations from 1850 to 1990 . Therefore for comparison, we repeated the analysis using the constant airborne fraction estimated by Knorr (2009) over this period ( $f=0.43$ ), which resulted in a $30 \%$ decrease in the computed RF.

After calculating the new atmospheric $\mathrm{CO}_{2}$ concentration, the Ramaswamy et al. (2001) simple expression for estimating the RF of $\mathrm{CO}_{2}$ was used for the final step in the calculation.

$\Delta F=5.35 \times \ln \left(C / C_{o}\right)$

This function, in which $C$ is the perturbed atmospheric $\mathrm{CO}_{2}$ concentration and $C_{o}$ is the $\mathrm{CO}_{2}$ concentration in the unperturbed state, both in ppm, captures the impact of the $\mathrm{CO}_{2}$ saturation effect by which higher ambient concentrations of $\mathrm{CO}_{2}$ act to diminish the RF of additional $\mathrm{CO}_{2}$ inputs.

\section{$\mathrm{B} 2 \mathrm{CH}_{4} \mathrm{RF}$ calculation}

To compute the impact of fires on $\mathrm{CH}_{4}$ we apply the Osborne and Wigley (1994) $\mathrm{CH}_{4}$ mass-balance method with slight modifications that account for the perturbation lifetime (Wild and Prather, 2000), and for the direct $\mathrm{CH}_{4}$ emissions from fires. Osborne and Wigley (1994) define the methane mass balance as,

$d\left[\mathrm{CH}_{4}\right]_{o} / d t=E_{o} / \beta-\left[\mathrm{CH}_{4}\right]_{o} / \tau_{o}$

where $\left[\mathrm{CH}_{4}\right]_{o}$ is the observed or predicted global mean surface concentration, $t$ is time, $E_{o}$ is the total emission of methane from all sources, $\beta=2.75$ is a proportionality constant, and $\tau_{o}$ is the methane lifetime considering all sources. The lifetime, $\tau$, is computed from the model global mean $\left[\mathrm{CH}_{4}\right]$ and $[\mathrm{OH}]$ below $200 \mathrm{hPa}$ for all CHEM simulations, and using the temperature dependent reaction rate constant from Seinfeld and Pandis (2006). If we assume a steady-state for $\left[\mathrm{CH}_{4}\right]$ (i.e. $\mathrm{d}\left[\mathrm{CH}_{4}\right]_{o} / \mathrm{d} t=0$ ) the following expression results.

$E_{o}=\frac{\left[\mathrm{CH}_{4}\right]_{o} \beta}{\tau_{o}}$

Next, to estimate the change in $\left[\mathrm{CH}_{4}\right]$ due to removing fires, $\Delta\left[\mathrm{CH}_{4}\right]$, for the model-calculated change in $\tau$ due to removing fires, $\Delta \tau$, at a new steady-state, we use $E_{o}$ from Eq. (B3) in the following expression adapted from Naik et al. (2005):

$\Delta\left[\mathrm{CH}_{4}\right]=F * E_{o} * \Delta \tau$
The parameter $F$ accounts for the positive feedback between $\left[\mathrm{CH}_{4}\right]$ and $[\mathrm{OH}]$ that occurs on the primary mode timescale (Wild and Prather, 2000; Fiore et al., 2009). It can be defined as the ratio of the adjustment time for $\left[\mathrm{CH}_{4}\right]$ after a perturbation to the mean $\left[\mathrm{CH}_{4}\right]$ lifetime. Here we use $F=1.4$ as recommended by Prather et al. (2001).

Finally, the impact of direct emissions of $\mathrm{CH}_{4}$ from fires on steady-state $\left[\mathrm{CH}_{4}\right]$ is computed separately using the change in $\mathrm{CH}_{4}$ emission caused by removing fires, $\Delta E$, and a form of the mass balance Eq. (B3) from Osborne and Wigley (1994) (their Eq. 11), where $F$ is used to represent the ratio of the perturbation lifetime to the initial lifetime:

$\Delta\left[\mathrm{CH}_{4}\right]=F \cdot \Delta E / E_{o} \cdot\left[\mathrm{CH}_{4}\right]_{o}$

The changes in $\left[\mathrm{CH}_{4}\right]$ due to the removal of fires, both from modifying the oxidant distribution of the atmosphere and from reducing direct $\mathrm{CH}_{4}$ emissions, are then added together to give the steady-state no-fire $\mathrm{CH}_{4}$ concentration, $\left[\mathrm{CH}_{4}\right]_{n f}$. The global mean RF due to $\mathrm{CH}_{4}$ from fires for each time period is then considered to be the difference in total RF between $\left[\mathrm{CH}_{4}\right]_{o}$ and $\left[\mathrm{CH}_{4}\right]_{n f}$. The RF computation follows the method given by Ramaswamy et al. (2001):

$$
\begin{aligned}
& \Delta F=0.036\left(\sqrt{\mathrm{M}}-\sqrt{\mathrm{M}_{o}}\right)-\left[\mathrm{f}\left(\mathrm{M}, \mathrm{N}_{o}\right)-\mathrm{f}\left(\mathrm{M}_{o}, \mathrm{~N}_{o}\right)\right] \\
& \mathrm{f}(\mathrm{M}, \mathrm{N})= \\
& 0.47 \ln \left[1+2.01 \times 10^{-5}(\mathrm{MN})^{0.75}+5.31 \times 10^{-15} \mathrm{M}(\mathrm{MN})^{1.52}\right]
\end{aligned}
$$

where $\mathrm{M}$ and $\mathrm{N}$ are average tropospheric concentrations of $\mathrm{CH}_{4}$ and $\mathrm{N}_{2} \mathrm{O}$ (in ppb), respectively, and $\mathrm{M}_{o}$ and $\mathrm{N}_{o}$ are the concentrations of those species in the unperturbed state.

\section{B3 $\quad \mathbf{N}_{2} \mathrm{O}$ box model}

The box model we use to compute the impact of fire emissions on $\mathrm{N}_{2} \mathrm{O}$ concentrations is expressed by Kroeze et al. (1999) as,

$\frac{d C}{d t}=\frac{S}{F}-\frac{C}{\tau}$

where $C$ is the $\mathrm{N}_{2} \mathrm{O}$ concentration (ppbv), $S$ are $\mathrm{N}_{2} \mathrm{O}$ emissions $\left(\mathrm{Tg} \mathrm{Nyr}^{-1}\right), \quad F$ is a conversion factor (4.8 $\mathrm{Tg} \mathrm{N} \mathrm{ppbv}^{-1}$ ), $t$ is time (years), and $\tau$ is the $\mathrm{N}_{2} \mathrm{O}$ lifetime (years). We account for the feedback of the changing $\mathrm{N}_{2} \mathrm{O}$ concentration onto its own lifetime following Meinshausen et al. (2011b).

$\tau=\tau_{o}\left(\frac{C}{C_{o}}\right)^{-0.05}$

where $\tau_{o}$ and $C_{o}$ are reference state values. In Eq. (B9) we use present-day numbers for the reference state (instead of pre-industrial values) of $C_{o}=316 \mathrm{ppbv}$ (Meinshausen et al., 2011a) and $\tau_{o}=114$ years (Forster et al., 2007). Using emissions data from the Meinshausen et al. (2011a) RCP4.5 time series, we ran the box model to a steady state $\mathrm{N}_{2} \mathrm{O}$ concentration $(d C / d t=0)$ for 1850,2000 , and 2100 anthropogenic 
and natural $\mathrm{N}_{2} \mathrm{O}$ emissions. We assume $\mathrm{N}_{2} \mathrm{O}$ uptake by the soil is accounted for in the emissions term and doesn't affect the atmospheric lifetime.

After these simulations that include all emissions, the emissions from fires are removed and the model is run to a new steady state. Due to the long lifetime of $\mathrm{N}_{2} \mathrm{O}$ in the atmosphere, the simulation can take several hundred model years to reach equilibrium after the emissions perturbation. The following expression from Ramaswamy et al. (2001) is used to compute the $\mathrm{RF}$ of the perturbed $\mathrm{N}_{2} \mathrm{O}$ concentration:

$\Delta F=0.12\left(\sqrt{N}-\sqrt{N}_{o}\right)-\left[\mathrm{f}\left(M_{o}, N\right)-\mathrm{f}\left(M_{o}, N_{o}\right)\right](\mathrm{B} 10)$

\section{B4 Post-fire albedo response calculation}

Trajectories of post-fire land surface albedo based on the literature were used for our analyses (Fig. B1). The first panel (Fig. B1a) shows relatively quick recoveries representative of tropical grasslands and savannas. Because rain removes $\mathrm{BC}$ and stimulates grass growth, these recovery rates depend on the seasonal timing of fire (Fisch et al., 1994; Beringer et al., 2003). While savanna albedos recover relatively quickly (within a year or two, depending on tree density and canopy scorch), long-term woody encroachment can occur within a couple decades in the absence of fire and cause a slight decrease in albedo (Brookman-Amissah et al., 1980; Higgins et al., 2007). This effect is shown in Fig. B1b but was not included in our RF estimate. Globally, there is a wide range of pre-fire grassland and savanna albedos. Underlying soil colour also varies substantially, and can influence the magnitude and sign of post-fire albedo changes (Fisch et al., 1994). We do not consider the impact of fires on the interdependence of atmospheric aerosol RF and surface albedo RF changes (Betts et al., 2007).

For this analysis we assume that extratropical grasses follow the same albedo recovery period as tropical grasses, regardless of season. We also use a similar recovery curve for boreal shrubs but extend the recovery period to three years, based on work by Veraverbeke et al. (2011).

Tropical forest fires cause increased albedos because of the emergence of secondary vegetation (Giambelluca et al., 1997). If not converted to agriculture or pasture, the landscape albedo recovers within a decade, even though mature trees and climax species have not yet been established. The last panel (Fig. B1c) represents albedo change from boreal forest fires in North America. After an initial decrease, summer albedo is increased for many decades because of a midsuccessional deciduous phase. Winter and spring albedo is increased dramatically because of snow exposure.

The curves given in Fig. B1 are applied to our model estimates of area burned and surface albedo using the following method. First, we compute the five year monthly mean surface albedos as the ratio of outgoing to incoming surface shortwave radiation at each model grid point, predicted by
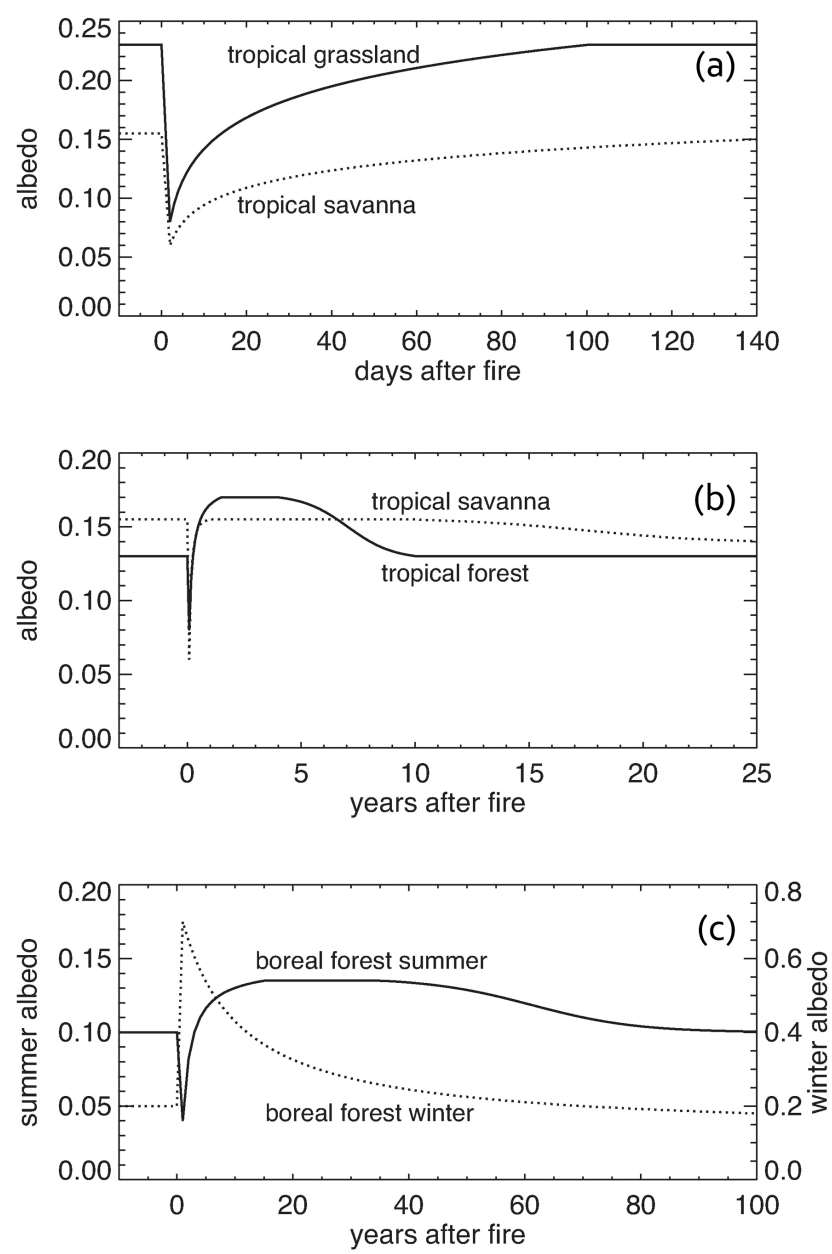

Fig. B1. Timeseries of surface albedo, estimated from past research, showing the recovery of different biomes from fire disturbance. Note the different timescales for (a) and (b) and the different y-axis values for the winter and summer fires in (c). These estimates were compiled from the following literature for tropical grasslands ${ }^{\mathrm{a}}$, tropical savanna ${ }^{\mathrm{b}}$, tropical forests ${ }^{\mathrm{c}}$, and boreal forests ${ }^{\mathrm{d}}$.

a Fisch et al., 1994; Fuller and Ottke, 2002; Jin and Roy, 2005; White and Loftin, 2000.

b Beringer et al., 2003; Brookan-Amissah et al., 1980; Govaerts et al., 2002; Higgins et al., 2007; Jin and Roy, 2005; Myhre et al., 2005.

c Culf et al., 1995; Giambelluca et al., 1997; Pinker et al., 1980.

d Amiro et al., 2006; Lyons et al., 2008; McMillan et al., 2008.

CAM5 in the AERO group of simulations that did not include fire emissions. Next we find the fraction of shortwave radiation leaving the surface that makes it back to the TOA. Using the computed albedos as the initial values for each point, we apply the albedo curves to the CLM3 or GFEDv2 fractional area burned and fractional PFTs (in each case using the time period specific databases) in each grid box. Tropical savanna was defined in PFT terms as $70 \%$ warm C4 grass and $30 \%$ tropical evergreen broadleaf tree with the proportions based on those used by Bonan et al. (2002). The winter 
albedo recovery curve was applied wherever monthly average snow depth water equivalent exceeded $1 \mathrm{~cm}$.

The change in albedo will act to increase or decrease the outgoing shortwave radiation from the surface. This is multiplied by the fraction of outgoing shortwave radiation that reaches the TOA, so that RF scales linearly with the outgoing surface shortwave radiation. This analysis is carried out on monthly, rather than annual, means so that the seasonal differences in albedo changes are accounted for. The impacts of the albedo changes on the radiation balance are computed for 100 years, after which all biomes have recovered and returned to their initial albedo.

Acknowledgements. We would like to thank Maria val Martin of Colorado State University for her assistance with the ACCMIP data and acknowledge funding from the National Science Foundation (NSF AGS-0758369; NSF AGS-1021613). We are also grateful for the comments from two anonymous reviewers that improved the content and clarity of this manuscript. Model integrations were performed with a National Center for Atmospheric Research facility, which is sponsored by the NSF.

Edited by: D. Spracklen

\section{References}

Amiro, B. D., Orchansky, A. L., Barr, A. G., Black, T. A., Chambers, S. D., Chapin III, F. S., Goulden, M. L., Litvak, M., Liu, H. P., and McCaughey, J. H.: The effect of post-fire stand age on the boreal forest energy balance, Agr. Forest Meteorol., 140, 41-50, doi:10.1016/j.agrformet.2006.02.014, 2006.

Andreae, M. O. and Merlet, P.: Emission of trace gases and aerosols from biomass burning, Global Biogeochem. Cy., 15, 955-966, 2001.

Andreae, M. O. and Rosenfeld, D.: Aerosol-cloud- precipitation interactions, Part 1, The nature and sources of cloud-active aerosols, Earth-Sci. Rev., 89, 13-41, doi:10.1016/j.earscirev.2008.03.001, 2008.

Archer, D., Eby, M., Brovkin, V, Ridgwell, A., Cao, L., Mikolajewicz, U., Cladeira, K., Matsumoto, K., Munhoven, G., Montenegro, A., and Tokos, K.: Atmospheric lifetime of fossil fuel carbon dioxide, Ann. Rev. Earth Pl. Sc., 37, 117-134, doi:10.1146/annurev.earth.031208.100206, 2009.

Arora, V. K. and Boer, G. J.: Fire as an interactive component of dynamic vegetation models, J. Geophys. Res., 110, G02008, doi:10.1029/2005JG000042, 2005.

Arora, V. K. and Boer, G. J.: Uncertainties in the 20th century carbon budget associated with land use change, Glob. Change Biol., 16, 3327-3348, doi:10.1111/j.1365-2486.2010.02202.x, 2010.

Beringer, J., Hutley, L. B., Tapper, N. J., Kerley, A., Coutts, A., and O'Grady, A. P.: Fire impacts on surface heat, moisture and carbon fluxes from a tropical savanna in northern Australia, Int. J. Wildland Fire, 12, 333-340, doi:10.1071/WF03023, 2003.

Betts, R. A., Falloon, P. D., Goldewijk, K. K., and Ramankutty, N.: Biogeophysical effects of land use on climate: Model simulations of radiative forcing and large-scale temperature change, Agr. Forest Meteorol., 142, 216-233, doi:10.1016/j.agrformet.2006.08.021, 2007.

Bian, H., Chin, M., Kawa, S. R., Duncan, B., Arellano, A., and Kasibhatla, P.: Sensitivity of global CO simulations to uncertainties in biomass burning sources, J. Geophys. Res., 112, D23308, doi:10.1029/2006JD008376, 2007.

Bonan, G. B., Oleson, K. W., Vertenstein, M., Levis, S., Zeng, X. B., Dai, Y. J., Dickinson, R. E., and Yang, Z. L.: The land surface climatology of the community land model coupled to the NCAR community climate model, J. Climate, 15, 3123-3149, doi:10.1175/1520-0442, 2002.

Bond, W. J., Woodward, F. I., and Midgley, G. F.: The global distribution of ecosystems in a world without fire, New Phytol., 165, 525-538, doi:10.1111/j.1469-8137.2004.01252.x, 2005.

Bowman, D. M. J. S., Balch, J. K., Artaxo, P., Bond, W. J., Carlson, J. M., Cochrane, M. A., D’Antonio, C. M., DeFries, R., Doyle, J. C., Harrison, S. P., Johnston, F. H., Keeley, J. E., Krawchuk, M. A., Kull, C. A., Marston, J. B., Mortiz, M. A., Prentice, I. C., Roos, C. I., Scott, A. C., Swetnam, T. W., van der Werf, G. R., and Pyne, S. J.: Fire in the Earth System, Science, 324, 481-484, doi:10.1126/science.1163886, 2009.

Brookman-Amissah, J., Hall, J. B., Swaine, M. D., and Attakorah, J. Y.: A re-assessment of a fire protection experiment in north-eastern Ghana savanna, J. Appl. Ecol., 17, 85-99, doi:10.2307/2402965, 1980.

Carslaw, K. S., Boucher, O., Spracklen, D. V., Mann, G. W., Rae, J. G. L., Woodward, S., and Kulmala, M.: A review of natural aerosol interactions and feedbacks within the Earth system, Atmos. Chem. Phys., 10, 1701-1737, doi:10.5194/acp-10-17012010, 2010.

Chen, Y., Randerson, J., van der Werf, G., Morton, D., Mu, M., and Kasibhatla, P.: Nitrogen deposition in tropical forests from savanna and deforestation fires, Global Change Biol., 16, 20242038, 2010.

Chin, M., Diehl, T., Dubovik, O., Eck, T. F., Holben, B. N., Sinyuk, A., Streets, D. G.: light absorption by pollution, dust, and biomass burning aerosols: a global model study and evaluation with AERONET measurements, Ann. Geophys., 27, 34393464, 2009, http://www.ann-geophys.net/27/3439/2009/.

Chuang, C. C., Penner, J. E., Prospero, J. M., Grant, K. E., Rau, G. H., Kawamoto, K.: Cloud susceptibility and the first aerosol indirect forcing: Sensitivity to black carbon and aerosol concentrations, J. Geophys. Res., 107, 4564, doi:10.1029/2000JD000215, 2002.

Cofer, W. R., Levine, J. S., Winstead, E. L., and Stocks, B. J.: New estimates of nitrous oxide emissions from biomass burning, Nature, 349, 689-691, 1991.

Crutzen, P. J. and Andreae, M. O.: Biomass burning in the tropics: impact on atmospheric chemistry and biogeochemical cycles, Science, 250, 1669-1678, 1990.

Culf, A. D., Fisch, G., and Hodnett, M. G.: The albedo of Amazonian forest and ranch land, J. Climate, 8, 1544-1554, doi:10.1175/1520-0442, 1995.

Decker, R. M. and Zeng, X.: Impact of modified richards equation on global soil moisture simulation in the Community Land Model (CLM3.5), J. Adv. Model. Earth Syst., 1, 22 pp., doi:10.3894/JAMES.2009.1.5, 2009. 
Dentener, F., Stevenson, D., Cofala, J., Mechler, R., Amann, M., Bergamaschi, P., Raes, F., and Derwent, R.: The impact of air pollutant and methane emission controls on tropospheric ozone and radiative forcing: CTM calculations for the period 19902030, Atmos. Chem. Phys., 5, 1731-1755, doi:10.5194/acp-51731-2005, 2005.

Emmons, L. K., Walters, S., Hess, P. G., Lamarque, J.-F., Pfister, G. G., Fillmore, D., Granier, C., Guenther, A., Kinnison, D., Laepple, T., Orlando, J., Tie, X., Tyndall, G., Wiedinmyer, C., Baughcum, S. L., and Kloster, S.: Description and evaluation of the Model for Ozone and Related chemical Tracers, version 4 (MOZART-4), Geosci. Model Dev., 3, 43-67, doi:10.5194/gmd3-43-2010, 2010.

Enting, I., Wigley, T. M. L., and Heimann, M.: Future Emissions and Concentrations of Carbon Dioxide: Key Ocean/Atmosphere/Land Analyses, CSIRO Division of Atmospheric Research Technical Paper, Australia, 31, 1994.

Fiore, A. M., Dentener, F. J., Wild, O., Cuvelier, C., Schultz, M. G., Hess, P., Textor, C., Schulz, M., Doherty, R. M., Horowitz, L. W., MacKenzie, I. A., Sanderson, M. G., Shindell, D. T., Stevenson, D. S., Szopa, S., Van Dingenen, R., Zeng, G., Atherton, C., Bergmann, D., Bey, I., Carmichael, G., Collins, W. J., Duncan, B. N., Faluvegi, G., Folberth, G., Gauss, M., Gong, S., Hauglustaine, D., Holloway, T., Isaksen, I. S. A., Jacob, D. J., Jonson, J. E., Kaminski, J. W., Keating, T. J., Lupu, A., Marmer, E., Montanaro, V., Park, R. J., Pitari, G., Pringle, K. J., Pyle, J. A., Schroeder, S., Vivanco, M. G., Wind, P., Wojcik, G., Wu, S., and Zuber, A.: Multimodel estimates of intercontinental sourcereceptor relationships for ozone pollution, J. Geophys. Res., 114, D04301, doi:10.1029/2008jd010816, 2009.

Fisch, G., Wright, I. R., and Bastable, H. G.: Albedo of tropical grass: A case study of pre and post burning, Int. J. Climatol., 14, 103-107, doi:10.1002/joc.3370140109, 1994.

Flanner, M. G. and Zender, C. S.: Snowpack radiative heating: Influence on Tibetan Plateau climate, J. Geophys. Res., 32, L06501, doi:10.1029/2004GL022076, 2005.

Flanner, M. G. and Zender, C. S.: Linking snowpack microphysics and albedo evolution, J. Geophys. Res., 111, D12208, doi:10.1029/2005JD006834, 2006.

Flanner, M. G., Zender, C. S., Randerson, J. T., and Rasch, P. J.: Present-day climate forcing and response from black carbon in snow, J. Geophys. Res., 112, D11202, doi:10.1029/2006JD008003, 2007.

Flanner, M. G., Zender, C. S., Hess, P. G., Mahowald, N. M., Painter, T. H., Ramanathan, V., and Rasch, P. J.: Springtime warming and reduced snow cover from carbonaceous particles, Atmos. Chem. Phys., 9, 2481-2497, doi:10.5194/acp-9-24812009, 2009.

Flannigan, M. D., Krawchuk, M. A., de Groot, W. J., Wotton, B. M., and Gowman, L. M.: Implications of changing climate for global wildland fire, Int. J. Wildland Fire, 18, 483-507, doi:10.1071/WF08187, 2009.

Forster, P., Ramaswamy, V., Artaxo, P., Berntsen, T., Betts, R., Fahey, D. W., Haywood, J., Lean, J., Lowe, D. C., Myhre, G., Nganga, J., Prinn, R., Raga, G., Schulz, M., and Dorland, R. V.: Changes in Atmospheric Constituents and in Radiative Forcing, in: Climate Change 2007: The Physical Science Basis. Contribution of Working Group I to the Fourth Assessment Report of the Intergovernmental Panel on Climate Change, edited by:
Solomon, S., Qin, D., Manning, M., Chen, Z., Marquis, M., Averyt, K. B., Tignor, M., and Miller, H. L., Cambridge Univ. Press, Cambridge and New York, 2007.

Friedlingstein, P. and Prentice, I. C.: Carbon-climate feedbacks: a review of model and observation based estimates, Current Opinion in Environmental Sustainability, 2, 251-257, 2010.

Friedlingstein, P., Cox, P., Betts, R., Bopp, L., von Bloh, W., Brovkin, V., Cadule, P., Doney, S., Eby, M., Fung, I., Bala, G., John, J., Jones, C., Joos, F., Kato, T., Kawamiya, M., Knorr, W., Lindsay, K., Matthews, H. D., Raddatz, T., Rayner, P., Reick, C., Roeckner, E., Schnitzler, K.-G., Schnur, R., Strassmann, K., Weaver, A. J., Yoshikawa, C., and Zeng, N.: Climate-carbon cycle feedback analysis, results from the C4MIP Model intercomparison, J. Climate, 19, 3337-3353, 2006.

Fuglestvedt, J. S., Bernsten, T. K., Isaksen, I. S. A., Mao, H., Liang, X.-Z., and Wang, W.-C.: Climatic forcing of nitrogen oxides through changes in tropospheric ozone and methane; global 3D model studies, Atmos. Environ., 33, 961-977, 1999.

Fuller, D. O. and Ottke, C.: Land cover, rainfall and landsurface albedo in West Africa, Clim. Change, 54, 181-204, doi:10.1023/A:1015730900622, 2002.

Galanter, M., Levy, H., and Carmichael, G. R.: Impacts of biomass burning on tropospheric $\mathrm{CO}, \mathrm{NO}_{\mathrm{x}}$, and $\mathrm{O}_{3}$, J. Geophys. Res.Atmos., 105, 6633-6653, 2000.

Giambelluca, T. W., Hölscher, D., Bastos, T. X., Frazão, R. R., Nullet, M. A., and Ziegler, A. D.: Observations of albedo and radiation balance over postforest land surfaces in the eastern Amazon basin, J. Climate, 10, 919-928, doi:10.1175/1520-0442, 1997.

Goodwin, P., Williams, R. G., Follows, M. J., and Dutkiewicz, S.: Ocean-atmosphere partitioning of anthropogenic carbon dioxide on centennial timescales, Global Biogeochem. Cy., 21, GB1014, doi:10.1029/2006GB002810, 2007.

Govaerts, Y. M., Pereira, J. M., Pinty, B., and Mota, B.: Impact of fires on surface albedo dynamics over the African continent, J. Geophys. Res.-Atmos., 107, 4629, doi:10.1029/2002JD002388, 2002.

Granier, C., Muller, J.-F., and Brasseur, G.: The impact of biomass burning on the global budget of ozone and ozone precursors. Biomass Burning and Its Interrelationship With the Climate System, edited by: Innes, J. L., Beniston, M., and Verstraete, M., 69-85, Kluwer Acad., Norwell, Mass., USA, 2000.

Guenther, A., Karl, T., Harley, P., Wiedinmyer, C., Palmer, P. I., and Geron, C.: Estimates of global terrestrial isoprene emissions using MEGAN (Model of Emissions of Gases and Aerosols from Nature), Atmos. Chem. Phys., 6, 3181-3210, doi:10.5194/acp-63181-2006, 2006.

Guieu, C., Bonnet, S., Wagener, T., and Loye-Pilot, M.-D.: Biomass Burning as a source of dissolved iron to the open ocean?, Geophys. Res. Lett., 22, L19608, doi:19610.11029/12005GL022962, 2005.

Hadley, O. L., Corrigan, C. E., Kirchstetter, T. W., Cliff, S. S., and Ramanathan, V.: Measured black carbon deposition on the Sierra Nevada snow pack and implication for snow pack retreat, Atmos. Chem. Phys., 10, 7505-7513, doi:10.5194/acp-10-75052010, 2010.

Hansen, J., Sato, M., Ruedy, R., Nazarenko, L., Lacis, A., Schmidt, G. A., Russell, G., Aleinov, I., Bauer, M., Bauer, S., Bell, N., Cairns, B., Canuto, V., Chandler, M., Cheng, Y., Del Genio, A., Faluvegi, G., Fleming, E., Friend, A., Hall, ?T., Jackman, C., Kel- 
ley, M., Kiang, N., Koch, D., Lean, J., Lerner, J., Lo, K., Menon, S., Miller, R., Minnis, P., Novakov, T., Oinas, V., Perlwitz, Ja., Perlwitz, Ju., Rind, D., Romanou, A., Shindell, D., Stone, P., Sun, S., Tausnev, N., Thresher, D., Wielicki, B., Wong, T., Yao, M., and Zhang, S.: Efficacy of climate forcings, J. Geophys. Res.Atmos., 110, D18104, doi:10.1029/2005JD005776, 2005.

Hanson, H. P.: Marine stratocumulus climatologies, Int. J. Climatol., 11, 147-164, 1991.

Harrison, S. P., Marlon, J. R., and Bartlein, P. J.: Fire in the earth system. Changing Climates, Earth Systems and Society, International Year of Planet Earth, Dodson, J., Springer, New York, USA, 2010.

Heald, C. L., Henze, D. K., Horowitz, L. W., Feddema, J., Lamarque, J.-F., Guenther, A., Hess, P. G., Vitt, F., Seinfeld, J. H., Goldstein, A. H., and Fung, I.: Predicted change in global secondary organic aerosol concentrations in response to future climate, emissions, and land use change, J. Geophys. Res.-Atmos., 113, D05211, doi:10.1029/2007JD009092, 2008.

Higgins, S. I., Bond, W. J., February, E. C., Bronn, A., EustonBrown, D. I. W., Enslin, B., Govender, N., Rademan, L., O'Regan, S., Potgieter, A. L. F., Scheiter, S., Sowry, R., Trollope, L., and Trollope, W. S. W.: Effects of four decades of fire manipulation on woody vegetation structure in savanna, Ecology, 88, 1119-1125, doi:10.1890/06-1664, 2007.

Hoelzemann, J. J., Schultz, M. G., Brasseur, G. P., Granier, C., and Simon, M.: Global Wildland Fire Emission Model (GWEM): Evaluating the use of global area burnt satellite data, J. Geophys. Res., 109, D14S04, doi:10.1029/2003JD003666, 2004.

Houghton, R. A., Hackler, J. L., and Lawrence, K. T.: The U.S. carbon budget: Contributions from land-use change, Science, 285, 574-578, 1999.

Hurtt, G. C., Frolking, S., Fearon, M. G., Moore, B., Shevliakova, E., Malyshev, S., Pacala, S. W., and Houghton, R. A.: The underpinnings of land-use history: three centuries of global gridded land-use transitions, wood-harvest activity, and resulting secondary lands, Global Change Biol., 12, 1208-1229, doi:10.1111/j.1365-2486.2006.01150.x, 2006.

Hurtt, G., Chini, L., Frolking, S., Betts, R., Feddema, J., Fisher, G., Fisk, J. P., Hibbard, K., Houghton, R., Janetos, A., Jones, C., Kinderman, G., Kinoshita, T., Goldewijk, K., Riahi, K., Shevliakova, E., Smith, S., Stehfest, E., Thomson, A., Thornton, P., van Vuuren, D., and Wang, Y.: Harmonization of land-use scenarios for the period 1500-2100: 600 years of global gridded annual land-use transitions, wood harvest, and resulting secondary lands, Clim. Change, 109, 117-161, doi:10.1007/s10584-0110153-2, 2011.

Hyer, E. J., Reid, J. S., and Zhang, J.: An over-land aerosol optical depth data set for data assimilation by filtering, correction, and aggregation of MODIS Collection 5 optical depth retrievals, Atmos. Meas. Tech., 4, 379-408, doi:10.5194/amt-4-379-2011, 2011.

Ito, A., Sudo, K., Akimoto, H., Sillman, S., and Penner, J. E.: Global modeling analysis of tropospheric ozone and its radiative forcing from biomass burning emissions in the twentieth century, J. Geophys. Res.-Atmos., 112, D24307, doi:10.1029/2007JD008745, 2007.

Jacobson, M. Z.: The short-term cooling but long-term global warming due to biomass burning, J. Climate, 17, 2909-2926, 2004.
Jin, Y. and Roy, D. P.: Fire-induced albedo change and its radiative forcing at the surface in northern Australia, Geophys. Res. Lett., 32, L13401, doi:10.1029/2005GL022822, 2005.

Johnston, F. H., Henderson, S. B., Chen, Y., Randerson, J. R., Marlier, M., DeFries, R. S., Kinney, P., Bowman, D. M., and Brauer, M.: Estimated global mortality attributable to smoke from landscape fires, Environ. Health Persp., 120, 695-701, doi:10.1289/ehp.1104422, 2012.

Jones, A., Roberts, D. L., Woodage, M., and Johnson, C.: Indirect sulphate aerosol forcing in a climate model with an interactive sulphur cylce, J. Geophys. Res.-Atmos., 106, 20293-20310, 2001.

Kahn, R. A., Gaitley, B. J., Martonchik, J. V., Diner, D. V., and Crean, K. A.: Multiangle Imaging Spectroradiometer (MISR) global aerosol optical depth validation based on 2 years of coincident Aerosol Robotic Network (AERONET) observations, J. Geophys. Res.-Atmos., 110, D10S04, doi:10.1029/2004JD004706, 2005.

Kloster, S., Mahowald, N. M., Randerson, J. T., Thornton, P. E., Homan, F. M., Levis, S., Lawrence, P. J., Feddema, J. J., Oleson, K. W., and Lawrence, D. M.: Fire dynamics during the 20th century simulated by the Community Land Model, Biogeosciences, 7, 1877-1902, doi:10.5194/bg-7-1877-2010, 2010.

Kloster, S., Mahowald, N. M., Randerson, J. T., and Lawrence, P. J.: The impacts of climate, land use, and demography on fires during the 21 st century simulated by CLM-CN, Biogeosciences, 9, 509-525, doi:10.5194/bg-9-509-2012, 2012.

Knorr, W.: Is the airborne fraction of anthropogenic $\mathrm{CO}_{2}$ emissions increasing?, Geophys. Res. Lett., 36, L21710, doi:10.1029/2009GL040613, 2009.

Koch, D., Schulz, M., Kinne, S., McNaughton, C., Spackman, J. R., Balkanski, Y., Bauer, S., Berntsen, T., Bond, T. C., Boucher, O., Chin, M., Clarke, A., De Luca, N., Dentener, F., Diehl, T., Dubovik, O., Easter, R., Fahey, D. W., Feichter, J., Fillmore, D., Freitag, S., Ghan, S., Ginoux, P., Gong, S., Horowitz, L., Iversen, T., Kirkeva, A., Klimont, Z., Kondo, Y., Krol, M., Liu, X., Miller, R., Montanaro, V., Moteki, N., Myhre, G., Penner, J. E., Perlwitz, J., Pitari, G., Reddy, S., Sahu, L., Sakamoto, H., Schuster, G., Schwarz, J. P., Seland, Ø., Stier, P., Takegawa, N., Takemura, T., Textor, C., van Aardenne, J. A., and Zhao, Y.: Evaluation of black carbon estimations in global aerosol models, Atmos. Chem. Phys., 9, 9001-9026, doi:10.5194/acp-9-9001-2009, 2009.

Koch, D. and Del Genio, A. D.: Black carbon semi-direct effects on cloud cover: review and synthesis, Atmos. Chem. Phys., 10, 7685-7696, doi:10.5194/acp-10-7685-2010, 2010.

Krishnamurthy, A., Moore, J. K., Mahowald, N., Luo, C., Doney, S. C., Lindsay, K., and Zender, C. S.: Impacts of increasing anthropogenic soluble iron and nitrogen deposition on ocean biogeochemistry, Global Biogeochem. Cy., 23, GB3016, doi:10.1029/2008GB003440, 2009.

Kroeze, C., Mosier, A., and Bouwman, L.: Closing the global N2O budget: a retrospective analysis 1500-1994, Global Biogeochem. Cy., 13, 1-8, 1999.

Lamarque, J.-F., Kiehl, J., Brasseur, G., Butler, T., Cameron-Smith, P., Collins, W. D., Collins, W. J., Granier, C., Hauglustaine, D., Hess, P., Holland, E., Horowitz, L., Lawrence, M., McKenna, D., Merilees, P., Prather, M., Rasch, P., Rotman, D., Shindell, D., and Thornton, P.: Assessing future nitrogen deposition and 
carbon cycle feedbacks using a multi-model approach: Analysis of nitrogen deposition, J. Geophys. Res., 110, D19303, doi:10.1029/2005JD005825, 2005.

Lamarque, J.-F., Bond, T. C., Eyring, V., Granier, C., Heil, A., Klimont, Z., Lee, D., Liousse, C., Mieville, A., Owen, B., Schultz, M. G., Shindell, D., Smith, S. J., Stehfest, E., Van Aardenne, J., Cooper, O. R., Kainuma, M., Mahowald, N., McConnell, J. R., Naik, V., Riahi, K., and van Vuuren, D. P.: Historical (1850-2000) gridded anthropogenic and biomass burning emissions of reactive gases and aerosols: methodology and application, Atmos. Chem. Phys., 10, 7017-7039, doi:10.5194/acp10-7017-2010, 2010.

Lamarque, J.-F., Emmons, L. K., Hess, P. G., Kinnison, D. E., Tilmes, S., Vitt, F., Heald, C. L., Holland, E. A., Lauritzen, P. H., Neu, J., Orlando, J. J., Rasch, P. J., and Tyndall, G. K.: CAM-chem: description and evaluation of interactive atmospheric chemistry in the Community Earth System Model, Geosci. Model Dev., 5, 369-411, doi:10.5194/gmd-5-369-2012, 2012.

Lawrence, D. M. and Slater, A. G.: Incoporating organic soil into a global climate model, Clim. Dynam., 30, 2-3, doi:10.1007/s00382-007-0278-1, 2008.

Lawrence, D. M. and Slater, A. G.: The contribution of snow condition trends to future ground climate, Clim. Dynam., 34, 7-8, doi:10.1007/s00382-009-0537-4, 2009.

Lawrence, D. M., Oleson, K. W., Flanner, M. G., Thornton, P. E., Swenson, S. C., Lawrence, P. J., Zeng, X., Yang, Z.-L., Levis, S., Sakaguchi, K., and Bonan, Gordon B. a nd Slater, A. G.: Parameterization improvements and functional and structural advances in Version 4 of the Community Land Model, J. Adv. Model. Earth Syst., 3, 1-27, doi:10.1029/2011MS000045, 2011.

Liu, H., Randerson, J. T., Lindfors, J., and Chapin, F. S.: Changes in the surface energy budget after fire in boreal ecosystems of interior Alaska: An annual perspective. J. Geophys. Res.-Atmos., 10, D13101, doi:10.1029/2004JD005158, 2005.

Liu, X., Xie, S., Boyle, J., Klein, S. A., Shi, X., Wang, Z., Lin, W., Ghan, S. J., Earle, M., Liu, P. S. K., and Zelenyuk, A.: Testing cloud microphysics parameterizations in NCAR CAM5 with ISDAC and M-PACE observations, J. Geophys. Res.-Atmos., 116, D00T11, doi:10.1029/2011JD015889, 2011.

Liu, X., Easter, R. C., Ghan, S. J., Zaveri, R., Rasch, P., Shi, X., Lamarque, J.-F., Gettelman, A., Morrison, H., Vitt, F., Conley, A., Park, S., Neale, R., Hannay, C., Ekman, A. M. L., Hess, P., Mahowald, N., Collins, W., Iacono, M. J., Bretherton, C. S., Flanner, M. G., and Mitchell, D.: Toward a minimal representation of aerosols in climate models: description and evaluation in the Community Atmosphere Model CAM5, Geosci. Model Dev., 5, 709-739, doi:10.5194/gmd-5-709-2012, 2012.

Lohmann, U. and Feichter, J.: Global indirect aerosol effects: a review, Atmos. Chem. Phys., 5, 715-737, doi:10.5194/acp-5-7152005, 2005.

Lyons, E. A., Jin, Y., Randerson, J. T., and Hall, C.: Changes in surface albedo after fire in boreal forest ecosystems of interior Alaska assessed using MODIS satellite observations, J. Geophys. Res.-Biogeo., 113, G02012, doi:10.1029/2007JG000606, 2008.

Mahowald, N.: Aerosol indirect effect on biogeochemistry and climate, Science, 334, 794-796, 2011.

Mahowald, N., Artaxo, P., Baker, A., Jickells, T., Okin, G., Randerson, J., and Townsend, A.: Impact of biomass burning emissions and land use change on Amazonian atmospheric cycling and deposition of phosphorus, Global Biogeochem. Cy., 19, GB4030, 4010.1029/2005GB002541, 2005.

Mahowald, N. M., Lindsay, K., Rothenberg, D., Doney, S. C., Moore, J. K., Thornton, P., Randerson, J. T., and Jones, C. D.: Desert dust and anthropogenic aerosol interactions in the Community Climate System Model coupled-carbon-climate model, Biogeosciences, 8, 387-414, doi:10.5194/bg-8-387-2011, 2011a.

Mahowald, N. M., Ward, D. S., Kloster, S., Flanner, M. G., Heald, C. L., Heavens, N. G., Hess, P. G., Lamarque, J.-F., and Chuang, P. Y.: Aerosol impacts on climate and biogeochemistry, Annu. Rev. Env. Resour., 36, 45-74, doi:10.1146/annurevenviron-042009-094507, 2011b.

Mao, Y. H., Li, Q. B., Zhang, L., Chen, Y., Randerson, J. T., Chen, D., and Liou, K. N.: Biomass burning contribution to black carbon in the western United States mountain ranges, Atmos. Chem. Phys., 11, 11253-11266, doi:10.5194/acp-11-11253-2011, 2011.

Marlon, J. R., Bartlein, P. J., Carcaillet, C., Gavin, D. G., Higuera, P. E., Joos, F., Power, M. J., and Prentice, I. C.: Climate and human influences on global biomass burning over the past two millennia, Nature Geosci., 1, 697-702, doi:10.1038/ngeo313, 2008.

Martensson, E. M., Nilsson, E. D., de Leeuw, G., Cohen, L. H., and Hansson, H. C.: Laboratory simulations and parameterization of the primary marine aerosol production, J. Geophys. Res., 108, 4297, doi:10.1029/2002jd002263, 2003.

Martin, J., Gordon, R. M., and Fitzwater, S. E.: The case for iron, Limnol. Oceanogr., 36, 1793-1802, 1991.

Matichuk, R. I., Colarco, P. R., Smith, J. A., and Toon, O. B.: Modeling the transport and optical properties of smoke aerosols from African savanna fires during the Southern African Regional Science Initiative campaign (SAFARI 2000), J. Geophys. Res., 112, D08203, doi:10.1029/2006JD007528, 2007.

Matichuk, R. I., Colarco, P. R., Smith, J. A., and Toon, O. B.: Modeling the transport and optical properties of smoke plumes from South American biomass burning, J. Geophys. Res.-Atmos., 113, D07208, doi:10.1029/2007JD009005, 2008.

McMillan, A., Winston, G. C., and Goulden, M. L.: Age dependent response of boreal forest to temperature and rainfall variability, Global Change Biol., 14, 1904-1916, 10.1111/j.13652486.2008.01614.x, 2008.

Meehl, G., Washington, W., Santer, B., Collins W. D., Arblaster, J. M., Hu, A., Lawrence, D. M., Teng, H., Buja, L. E., and Strand, W. G.: Climate change projections for the twenty-first century and climate change commitment in the CCSM3, J. Climate, 19, 2597-2616, 2006.

Meinshausen, M., Smith, S. J., Calvin, K., Daniel, J. S., Kainuma, M. L. T., Lamarque, J-F., Matsumoto, K., Montzka, S. A., Raper, S. C. B., Riahi, K., Thomson, A., Velders, G. J. M., and van Vuuren, D. P. P.: The RCP greenhouse gas concentrations and their extensions from 1765 to 2300, Climatic Change, 109, 213-241, doi:10.1007/s10584-011-0156-z, 2011a.

Meinshausen, M., Raper, S. C. B., and Wigley, T. M. L.: Emulating coupled atmosphere-ocean and carbon cycle models with a simpler model, MAGICC6 - Part 1: Model description and calibration, Atmos. Chem. Phys., 11, 1417-1456, doi:10.5194/acp11-1417-2011, $2011 b$.

Mercado, L. M., Belloui, N., Sitch, S., Boucher, O., Huntingford, C., Wild, M. and Cox, P. M.: Impact of changes in diffuse radiation on the global land carbon sink, Nature, 458, 1014-1017, 
2009.

Mieville, A., Granier, C., Liousse, C., Guillaume, B., Mouillot, F., Lamarque, J. F., Gregoire, J. M., and Petron, G.: Emissions of gases and particles from biomass burning during the 20th century using satellite data and a historical reconstruction, Atmos. Environ., 44, 1469-1477, doi:10.1016/j.atmosenv.2010.01.011, 2010.

Monahan, E. C., Spiel, D. E., and Davidson, K. L.: A model of marine aerosol generation via whitecaps and wave disruption, in: Oceanic Whitecaps, edited by: Monahan, E. C. and Mac Niocaill, G., 167-174, D. Reidel, Norwell, Mass., USA, 1986.

Moss, R. H., Edmonds, J. A., Hibbard, K. A., Manning, M. R., Rose, S. K., van Vuuren, D. P., Carter, T. R., Emori, S., Kainuma, M., Kram, T., Meehl, G. A., Mitchell, J. F. B., Nakicenovix, N., Riahi, K., Smith, S. J., Stouer, R. J., Thomson, A. M., Weyant, J. P., and Wilbanks, T. J.: The next generation of scenarios for climate change research and assessment, Nature, 463, 747-756, doi:10.1038/nature08823, 2010.

Morrison, H. and Gettelman, A.: A new two-moment bulk stratiform cloud microphysics scheme in the community atmosphere model, version 3 (CAM3). Part I: Description and numerical tests, J. Climate, 21, 3642-3659, doi:10.1175/2008jcli2105.1, 2008.

Myhre, G., Govaerts, Y., Haywood, J. M., Berntsen, T. K., and Lattanzio, A.: Radiative effect of surface albedo change from biomass burning, Geophys. Res. Lett, 32, L20812, doi:10.1029/2005GL022897, 2005.

Naik, V., Mauzerall, D., Horowitz, L., Schwarzkopf, M. D., Ramaswamy, V., and Oppenheimer, M.: Net radiative forcing due to changes in regional emissions of tropospheric ozone precursors, J. Geophys. Res.-Atmos., 110, D24306, doi:10.1029/2005JD005908, 2005.

Naik, V., Mauzerall, D., Horowitz, L., Schwarzkopf, M. D., Ramaswamy, V., and Oppenheimer, M.: On the sensitivity of radiative forcing from biomass burning aerosols and ozone to emission location, Geophys. Res. Lett., 34, L03818, doi:10.1029/2006GL028149, 2007.

Nakicenovic, N., Davidson, O., Davis, G., Gruebler, A., Kram, T., La Rovere, E. L., Metz, B., Morita, T., Pepper, W., Pitcher, H., Sankovski, A., Shukla, P., Swart, R., Watson, R., and Dadi, Z.: Special Report on Emissions Scenarios, in: Contribution to the Intergovernmental Panel on Climate Change, Cambridge University Press, Cambridge, UK, 2000.

Nevison, C. D., Mahowald, N. M., Doney, S. C., Lima, I. D., van der Werf, G. R., Randerson, J. T., Baker, D. F., Kasibhatla, P., and McKinley, G. A.: Contribution of ocean, fossil fuel, land biosphere, and biomass burning carbon fluxes to seasonal and interannual variability in atmospheric CO_2. J. Geophys. Res.Biogeo, 113, G01010, doi:10.1029/2007JG000408, 2008.

Niu, G.-Y. and Yang, Z.-L.: An observation-based formulation of snow cover fraction and its evaluation over large North American river basins, J. Geophys. Res.-Atmos., 112, D21101, doi:10.1029/2007JD008674, 2007.

O'Halloran, T. L., Law, B. E., Goulden, M. L., Wang, Z., Barr, J. G., Schaaf, C., Brown, M., Fuentes, J. D., Gockede, M., Black, A., and Engel, V.: Radiative forcing of natural forest disturbances, Glob. Change Biol., 18, 555-565, doi:10.1111/j.13652486.2011.02577.x, 2012.

Oleson, K. W., Niu, G.-Y., Yang, Z.-L., Lawrence, D. M., Thornton, P. E., Lawrence, P. J., Stoeckli, R., Dickinson, R. E., Bonan, G.
B., Levis, S., Dai, A., and Qian, T.: Improvements to the Community Land Model and their impact on the hydrological cyle., J. Geophys. Res., 113, G01021, doi:10.1029/2007JG000563, 2008a.

Oleson, K. W., Bonan, G. B., Feddema, J., Vertenstein, M., and Grimmong, C. S. B.: An urban paramterization for a global climate model. 1. Formulation and evaluation of two cities, J. Appl. Meteorol. Clim., 47, 1038-1060, 2008b.

Osborne, T. J. and Wigley, T. M. L.: A simple model for estimating methane concentration and lifetime variations, Clim. Dynam., 9, 181-193, 1994.

Pechony, O. and Shindell, D. T.: Driving forces of global wildfires over the past millennium and the forthcoming century, P. Natl. Acad. Sci., 107, 19167-19170, doi:10.1073/pnas.1003669107, 2010.

Pfister, G. G., Emmons, L. K., Hess, P. G., Honrath, R., Lamarque, J.-F., Val Martin, M., Owen, R. C., Avery, M. A., Browell, E. V., Holloway, J. S., Nedelec, P., Purvis, R., Ryerson, T. B., Sachse, G. W., and Schlager, H.: Ozone production from the 2004 North American boreal fires, J. Geophys. Res.-Atmos., 111, D24S07, doi:10.1029/2006JD007695, 2006.

Pfister, G. G., Wiedinmyer, C., and Emmons, L. K.: Impacts of the fall 2007 California wildfires on surface ozone: Integrating local observations with global model simulations, Geophys. Res. Lett., 35, L19814, doi:10.1029/2008GL034747, 2008.

Pinker, R. T., Thompson, O. E., and Eck, T. F.: The albedo of a tropical evergreen forest, Q. J. Roy. Meteor. Soc., 106, 551-558, doi:10.1256/smsqj.44910, 1980.

Prather, M., Ehhalt, D., Dentener, F., Derwent, R., Dlugokencky, E., Holland, E., Isaksen, I., Katima, J., Kirchoff, V., Matson, P., Midgley, P., and Wang, M.: Atmospheric chemistry and greenhouse gases, in Climate Change 2001, The scientific basis, edited by: Houghton, J. T., Ding, Y., Griggs, D. J., Noguer, M., Van der Linden, P. J., Dai, X., Maskell, K., and Johnson, C. A., Intergovernmental Panel on Climate Change, Cambridge University Press, Cambridge, 239-287, 2001.

Prentice, I. C., Kelley, D. I., Foster, P. N., Friedlingstein, P., Harrison, S. P., and Bartlein, P. J.: Modeling fire and the terrestrial carbon balance, Glob. Biogeochem. Cy., 25, GB3005, doi:10.1029/2010GB003906, 2011.

Qian, T., Dai, A., Trenberth, K. E., and Oleson, K. W.: Simulation of Global Land Surface Conditions from 1948 to 2004. Part I: Forcing Data and Evaluations, J. Hydrometeorol., 7, 953, doi:10.1175/JHM540.1, 2006.

Quaas, J., Ming, Y., Menon, S., Takemura, T., Wang, M., Penner, J. E., Gettelman, A., Lohmann, U., Bellouin, N., Boucher, O., Sayer, A. M., Thomas, G. E., McComiskey, A., Feingold, G., Hoose, C., Kristjánsson, J. E., Liu, X., Balkanski, Y., Donner, L. J., Ginoux, P. A., Stier, P., Grandey, B., Feichter, J., Sednev, I., Bauer, S. E., Koch, D., Grainger, R. G., Kirkevåg, A., Iversen, T., Seland, Ø., Easter, R., Ghan, S. J., Rasch, P. J., Morrison, H., Lamarque, J.-F., Iacono, M. J., Kinne, S., and Schulz, M.: Aerosol indirect effects - general circulation model intercomparison and evaluation with satellite data, Atmos. Chem. Phys., 9, 8697-8717, doi:10.5194/acp-9-8697-2009, 2009.

Ramaswamy, V., Boucher, O., Haigh, J., Hauglustaine, D., Haywood, J., Myhre, G., Nakajima, T., Shi, G. Y., and Solomon, S.: Radiative forcing of climate change, in: Climate Change 2001. The Scientific Basis, Cambridge University Press, Cambridge, 
UK, 349-416, 2001.

Randerson, J. T., Liu, H., Flanner, M. G., Chambers, S. D., Jin, Y., Hess, P. G., Pfister, G., Mack, M. C., Treseder, K. K., Welp, L. R., Chapin, F. S., Harden, J. W., Goulden, M. L., Lyons, E., Ne, J. C., Schuur, E. A. G., and Zender, C. S.: The impact of boreal forest fire on climate warming, Science, 314, 1130-1132, doi:10.1126/science.1132075, 2006.

Real, E., Law, K. S., Weinzierl, B., Fiebig, M., Petzold, A., Wild, O., Methven, J., Arnold, S., Strohl, A., Huntrieser, H., Roiger, A., Schlager, H., Stewart, D., Avery, M., Sachse, G., Browell, E., Ferrare, R., and Blake, D.: Processes influencing ozone levels in Alaskan forest fire plumes during long-range transport over the North Atlantic, J. Geophys. Res.-Atmos., 112, D10S41, doi:10.1029/2006JD007576, 2007.

Reddy, M. S., Boucher, O., Balkanski, Y., and Schulz, M.: Aerosol optical depths and direct radiative perturbations by species and source type, Geophys. Res. Lett., 32, L12803, doi:10.1029/2004GL021743, 2005.

Roeckner, E., Brasseur, G., Giorgetta, M., Jacob, D., Jungclaus, J., Reick, C., and Sillmann, J.: Climate Projections for the 21st Century, in: Internal Report, p. 28, Max Planck Institut fuer Meteorologie, available at: http://www.mpimet.mpg.de/fileadmin/ grafik/presse/ClimateProjections2006.pdf, last access: December 2011, 2006

Rogers, B. M., Neilson, R. P., Drapek, R., Lenihan, J. M., Wells, J. R., Bachelet, D., and Law, B. E.: Impacts of climate change on fire regimes and carbon stocks of the U. S. Pacific Northwest, J. Geophys. Res.-Biogeo., 116, G03037, doi:10.1029/2011JG001695, 2011.

Sakaguchi, K. and Zeng, X.: Effects of soil wetness, plant litter, and under-canopy atmospheric stability on ground evaporation in the Community Land Model (CLM3.5), J. Geophys. Res., 114, D01107, doi:10.1029/2008JD010834, 2009.

Sakaeda, N., Wood, R., and Rasch, P. J.: Direct and semidirect aerosol effects of southern African biomass burning aerosol, J. Geophys. Res.-Atmos., 116, D12205, doi:10.1029/2010JD015540, 2011.

Schmidt, A., Carslaw, K. S., Mann, G. W., Rap, A., Pringle, K. J., Spracklen, D. V., Wilson, M., and Forster, P. M.: Importance of tropospheric volcanic aerosol for indirect radiative forcing of climate, Atmos. Chem. Phys., 12, 7321-7339, doi:10.5194/acp-127321-2012, 2012.

Schwarz, J. P., Gao, R. S., Spackman, J. R., Watts, L. A., Thomson, D. S., Fahey, D. W., Ryerson, T. B., Peischl, J., Holloway, J. S., Trainer, M., Frost, G. J., Baynard, T., Lack, D. A., de Gouw, J. A., Warneke, C., and Del Negro, L. A.: Measurement of the mixing state, mass, and optical size of individual black carbon particles in urban and biomass burning emissions, Geophys. Res. Lett., 35, L13810, doi:10.1029/2008GL033968, 2008.

Seinfeld, J. H. and Pandis, S. N.: Atmospheric Chemistry and Physics: From air Pollution to Climate Change, Second Edition, Wiley-Interscience, New York, 2006.

Siegenthaler, U. and Joos, F.: Use of a simple model for studying oceanic tracer distributions and the global carbon cycle, Tellus, 44, 186-207, 1992.

Solomon, S., Qin, D., Manning, M., Chen, Z., Marquis, M., Averyt, K. B., Tignor, M., and Miller, H. L. (Eds.): Contribution of Working Group I to the Fourth Assessment Report of the Inter- governmental Panel on Climate Change, 996 pp., Cambridge University
Press, Cambridge, UK and New York, NY, USA, 2007.

Stoeckli, R., Lawrence, D. M., Niu, G.-Y., Oleson, K. W., Thornton, P. E., Yang, Z.-L., Bonan, G. B., Denning, A. S., and Running, S. W.: The use of Fluxnet in the Community Land Model development, J. Geophys. Res., 113, G01025, doi:10.1029/2007JG000562, 2008.

Stohl, A., Berg, T., Burkhart, J. F., Fjaeraa, A. M., Forster, C., Herber, A., Hov, O., Lunder, C., McMillan, W. W., Oltmans, S., Shiobara, M., Simpson, D., Solberg, S., Stebel, K., Strom, J., Torseth, K., Treffeisen, R., Virkkunen, K., and Yttri, K. E.: Arctic smoke - record high air pollution levels in the European Arctic due to agricultural fires in Eastern Europe in spring 2006, Atmos. Chem. Phys., 7, 511-534, doi:10.5194/acp-7-511-2007, 2007.

Stone, R. S., Augustine, J. A., Dutton, E. G., O’Neill, N. T., and Saha, A.: Empirical determinations of the longwave and shortwave radiative forcing efficiencies of wildfire smoke, J. Geophys. Res.-Atmos., 116, D12207, doi:10.1029/2010JD015471, 2011.

Syakila, A. and Kroeze, C.: The global nitrous oxide budget revisited, Greenhouse Gas Measurement and Management, 1, 17-26, doi:10.3763/ghgmm.2010.0007, 2011.

Thonicke, K., Venevsky, S., Sitch, S., and Cramer, W.: The role of fire disturbance for global vegetation dynamics: coupling fire into a Dynamic Global Vegetation Model, Global Ecol. Biogeogr., 10, 661-678, 2001.

Thonicke, K., Spessa, A., Prentice, I. C., Harrison, S. P., Dong, L., and Carmona-Moreno, C.: The influence of vegetation, fire spread and fire behaviour on biomass burning and trace gas emissions: results from a process-based model, Biogeosciences, 7 , 1991-2011, doi:10.5194/bg-7-1991-2010, 2010.

Thornton, P. E., Lamarque, J. F., Rosenbloom, N. A., and Mahowald, N. M.: Influence of carbon-nitrogen cycle coupling on land model response to $\mathrm{CO}_{2}$ fertilization and climate variability, Global Biogeochem. Cy., 21, GB4018, doi:1029/2006GB002868, 2007.

Thornton, P. E., Doney, S. C., Lindsay, K., Moore, J. K., Mahowald, N., Randerson, J. T., Fung, I., Lamarque, J.-F., Feddema, J. J., and Lee, Y.-H.: Carbon-nitrogen interactions regulate climate-carbon cycle feedbacks: results from an atmosphereocean general circulation model, Biogeosciences, 6, 2099-2120, doi:10.5194/bg-6-2099-2009, 2009.

Tosca, M. G., Randerson, J. T., Zender, C. S., Flanner, M. G., and Rasch, P. J.: Do biomass burning aerosols intensify drought in equatorial Asia during El Nino, Atmos. Chem. Phys., 10, 3515 3528, doi:10.5194/acp-10-3515-2010, 2010.

Tosca, M. G., Randerson, J. T., Zender, C. S., Nelson, D. L., Diner, D. J., and Logan, J. A.: Dynamics of fire plumes and smoke clouds associated with peat and deforestation fires in Indonesia, J. Geophys. Res.-Atmos, 116, D08207, doi:10.1029/2010JD015148, 2011.

Tosca, M. G., Randerson, J. T., and Zender, C. S.: Global impact of contemporary smoke aerosols from landscape fires on climate and the Hadley circulation, Atmos. Chem. Phys. Disc., 12, 28069-28108, doi:10.5194/acpd-12-28069-2012, 2012.

Turetsky, M. R., Amiro, B. D., Bosch, E., and Bhatti, J. S.: Historical burn area in western Canadian peatlands and its relationship to fire weather indices. Glob. Biogeochem. Cy., 18, GB4014, doi:10.1029/2004GB002222, 2004.

val Martin, M., Logan, J. A., Kahn, R. A., Leung, F.-Y., Nelson, D. L., and Diner,D. J.: Smoke injection heights from fires in 
North America: analysis of 5 years of satellite observations, Atmos. Chem. Phys., 10, 1491-1510, doi:10.5194/acp-10-14912010, 2010.

van der Werf, G. R., Randerson, J. T., Giglio, L., Collatz, G. J., Kasibhatla, P. S., and Arellano Jr., A. F.: Interannual variability in global biomass burning emissions from 1997 to 2004, Atmos. Chem. Phys., 6, 3423-3441, doi:10.5194/acp-6-3423-2006, 2006.

van der Werf, G. R., Randerson, J. T., Giglio, L., Collatz, G. J., Mu, M., Kasibhatla, P. S., Morton, D. C., DeFries, R. S., Jin, Y., and van Leeuwen, T. T.: Global fire emissions and the contribution of deforestation, savanna, forest, agricultural, and peat fires (19972009), Atmos. Chem. Phys., 10, 11707-11735, doi:10.5194/acp10-11707-2010, 2010.

Veraverbeke, S., Lhermitte, S., Verstraeten, W. W., and Goossens, R.: A time-integrated MODIS burn severity assessment using the multi-temporal differenced normalized burn ratio $\left(\mathrm{dNBR}_{\mathrm{MT}}\right)$, Int. J. Appl. Earth Obs., 13, 52-58, doi:10.1016/j.jag.2010.06.006, 2011.

Vitousek, P.: Litterfall, nutrient cycling and nutrient limitations in tropical forests, Ecology, 65, 285-298, 1984.

Wang, A. H. and Zeng, X. B.: Improving the treatment of the vertical snow burial fraction over short vegetation in the NCAR CLM3, Adv. Atmos. Sci., 26, 877-886, doi:10.1007/s00376009-80983, 2009.
Wang, M., Ghan, S., Ovchinnikov, M., Liu, X., Easter, R., Kassianov, E., Qian, Y., and Morrison, H.: Aerosol indirect effects in a multi-scale aerosol-climate model PNNL-MMF, Atmos. Chem. Phys., 11, 5431-5455, doi:10.5194/acp-11-5431-2011, 2011.

White, C. S. and Loftin, S. R.: Response of 2 semiarid grasslands to cool-season prescribed fire, J. Range Manage., 53, 52-61, doi:10.2307/4003392, 2000.

Wilcox, E. M.: Stratocumulus cloud thickening beneath layers of absorbing smoke aerosol, Atmos. Chem. Phys., 10, 1176911777, doi:10.5194/acp-10-11769-2010, 2010.

Wild, O. and Prather, M. J.: Excitation of the primary tropospheric chemical mode in a global 3-D model, J. Geophys. Res., 105, 24647-24660, 2000.

Wild, O., Prather, M. J., and Akimoto, H.: Indirect long-term global radiative cooling from $\mathrm{NO}_{\mathrm{x}}$ emissions, Geophys. Res. Lett., 28, 1719-1722, 2001.

Zender, C., Bian, H., and Newman, D.: Mineral Dust Entrainment and Deposition (DEAD) model: Description and 1990s dust climatology, J. Geophys. Res., 108, 4416, doi:10.1029/2002JD002775, 2003.

Zhang, L., Li, Q. B., Jin, J., Liu, H., Livesey, N., Jiang, J. H., Mao, Y., Chen, D., Luo, M., and Chen, Y.: Impacts of 2006 Indonesian fires and dynamics on tropical upper tropospheric carbon monoxide and ozone, Atmos. Chem. Phys., 11, 10929-10946, doi:10.5194/acp-11-10929-2011, 2011. 